\title{
Kyrgyz Republic: Fifth Review Under the Three-Year Arrangement Under the Poverty Reduction and Growth Facility_Staff Report; Staff Supplement; Staff Statement; Press Release on the Executive Board Discussion; and Statement by the Executive Director for Kyrgyz Republic
}

In the context of the fifth review under the three-year arrangement under the Poverty Reduction and Growth Facility with the Kyrgyz Republic, the following documents have been released and are included in this package:

- $\quad$ The staff report for the Fifth Review Under the Three-Year Arrangement Under the Poverty Reduction and Growth Facility, prepared by a staff team of the IMF, following discussions that ended on August 30, 2007 with the officials of the Kyrgyz Republic on economic policies. Based on information available at the time of these discussions, the staff report was completed on November 2, 2007. The views expressed in the staff report are those of the staff team and do not necessarily reflect the views of the Executive Board of the IMF.

- $\quad$ A staff supplement on the joint World Bank/IMF debt sustainability analysis.

- $\quad$ A staff statement of November 16, 2007 updating information on recent economic developments;

- $\quad$ A Press Release, summarizing the views of the Executive Board as expressed during its November 16, 2007 discussion of the staff report; and

- $\quad$ A statement by the Executive Director for the Kyrgyz Republic.

The documents listed below have been or will be separately released.

Letter of Intent sent to the IMF by the authorities of the Kyrgyz Republic* Memorandum of Economic Policies by the authorities of the Kyrgyz Republic*

*Also included in Staff Report

The policy of publication of staff reports and other documents allows for the deletion of market-sensitive information.

To assist the IMF in evaluating the publication policy, reader comments are invited and may be sent by e-mail to publicationpolicy@imf.org.

Copies of this report are available to the public from

International Monetary Fund • Publication Services

$70019^{\text {th }}$ Street, N.W. • Washington, D.C. 20431

Telephone: (202) 623-7430 • Telefax: (202) 623-7201

E-mail: publications@imf.org •Internet: http://www.imf.org

Price: $\$ 18.00$ a copy

\section{International Monetary Fund Washington, D.C.}





\title{
INTERNATIONAL MONETARY FUND
}

\section{KYRGYZ REPUBLIC}

\section{Fifth Review Under the Three-Year Arrangement Under the Poverty Reduction and Growth Facility}

\author{
Prepared by the Middle East and Central Asia Department \\ (in cooperation with other departments)
}

Approved by David Owen (MCD) and Scott Brown (PDR)

November 2, 2007

\section{EXECUTIVE SUMMARY}

The economy is rebounding, but inflation has picked up sharply. Economic recovery, combined with firm fiscal discipline, has improved the country's debt indicators, which are now below HIPC thresholds. Performance under the PRGF-supported program has generally been good, with all end-June performance criteria met. In the calmer political environment of recent months, there has also been renewed progress on structural reforms. The main challenge for the authorities is to sustain the recovery by further building reform momentum, while preventing the recent upsurge in inflation - mostly the result of higher international wheat prices - from becoming entrenched.

Tight monetary policy and continued fiscal restraint are needed to contain inflation. Following the mission, the authorities have raised interest rates, cut back on intervention, and allowed a sharp appreciation of the exchange rate. They have also committed to undershoot the program's 2007 fiscal deficit target and maintain a cautious fiscal stance in 2008.

Progress on the reform agenda will underpin sustained growth and help to reduce vulnerabilities. Resolution of constitutional issues after October referendum should allow for closer cooperation between government and parliament in advancing critical reforms in the energy sector, as well as measures to foster good governance and transparency in public sector operations. Vigilance is needed regarding potential banking sector weaknesses, including any signs of contagion from banking sector problems in neighboring Kazakhstan.

Staff recommends completion of the $5^{\text {th }}$ review under the PRGF-supported arrangement. Continued compliance with the program's quantitative performance targets, the policy response to the recent uptick in inflation, and an improving political environment for reform all suggest that risks remain manageable. To permit Board consideration of the $6^{\text {th }}$ review and disbursement of the final tranche, staff supports the authorities' request for an extension of the existing arrangement to May 31, 2008. Staff looks forward to discussing modalities for future engagement with the Fund after expiry of the current arrangement. 
I. Recent Developments and Performance Under the Program........................................... 3

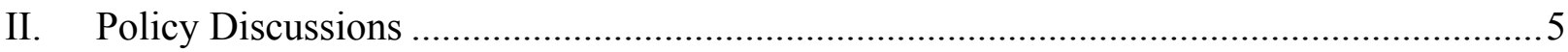

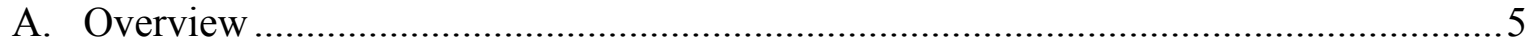

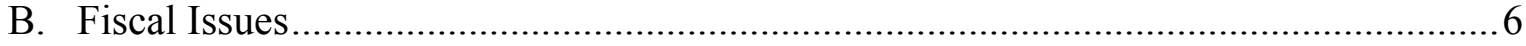

C. Monetary Policy and Financial Sector Reforms.................................................... 7

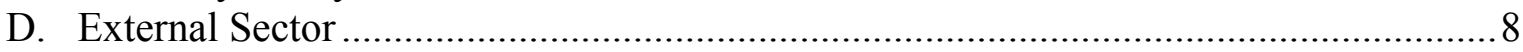

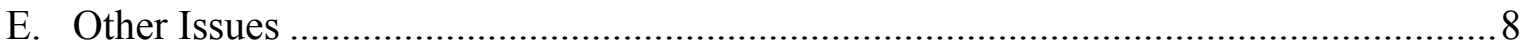

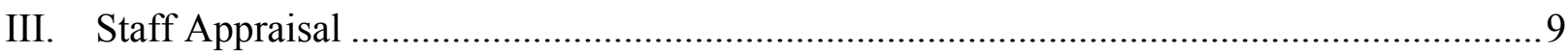

Figures

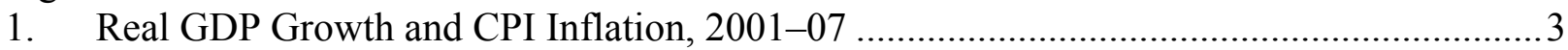

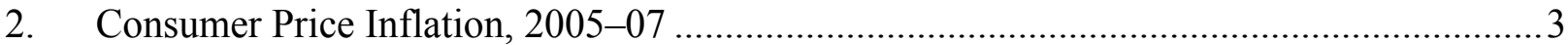

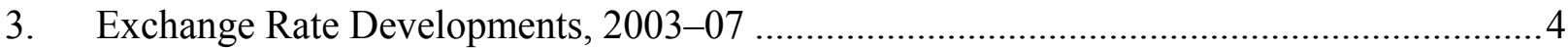

4. Monetary Developments, 2006-07 .......................................................................... 5

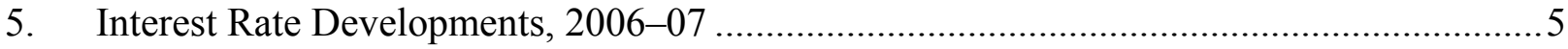

Tables

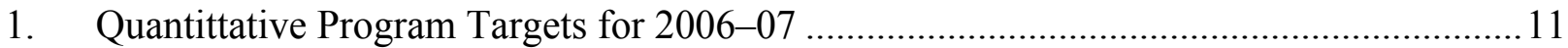

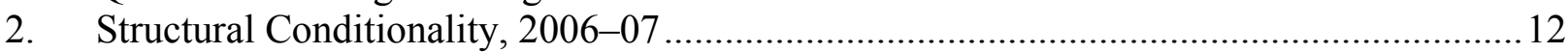

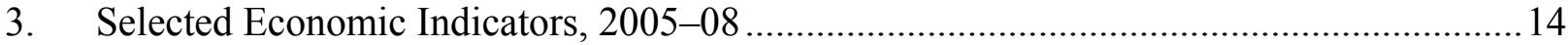

4. Summary of General Government Fiscal Operations, 2005-08 …..............................15

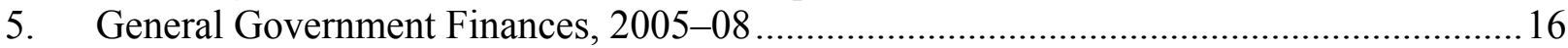

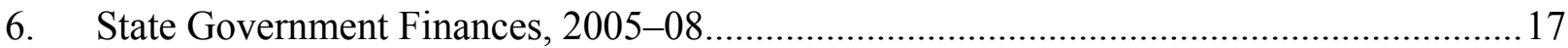

7. Social Fund Operations, 2005-08 ......................................................................... 18

8. Medium-Term Expenditure Framework for General Government by Functional

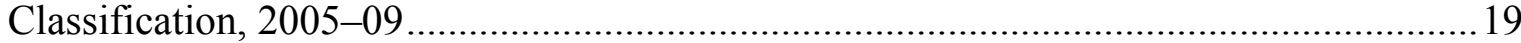

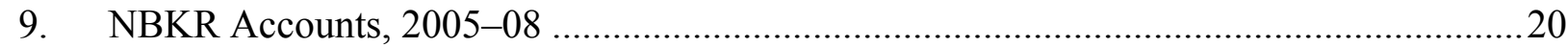

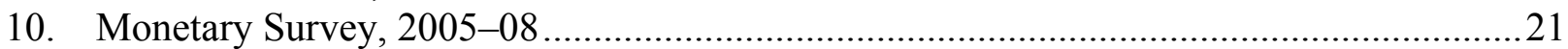

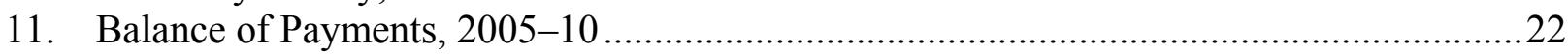

12. Indicators of Fund Credit, 2005-12 ......................................................................23

13. Prospective Use of Fund Resources, 2006-12 .........................................................24

14. Reviews and Disbursements Under the Three-Year PRGF Arrangement......................25

Attachments

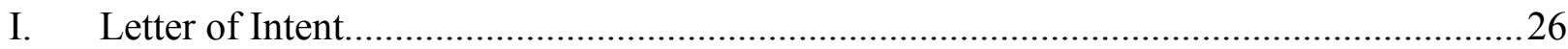

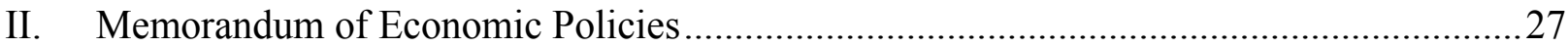




\section{Recent Developments And Performance Under the Program}

1. Political tensions have eased, but constitutional issues have taken center stage. Political stability was restored following the April opposition demonstrations, thanks in part to the appointment of an opposition leader, Mr. Atambaev, as prime minister and the creation of a working group to propose further constitutional changes. On October 21, a new draft constitution, which restores many of the powers that President Bakiev lost during last year's conflict with parliament, was overwhelmingly approved in a referendum. Following the referendum, the President called parliamentary elections under the new constitution for December 16.

2. Growth has accelerated, but inflation has picked up sharply. The economy continues to rebound, with year-on-year GDP growth of $81 / 2$ percent and nongold output growth of 9 percent during January-September, underpinned by booming activity in the construction and services sectors. However, demand pressures, fueled in part by loose monetary policy, coupled with soaring wheat prices, pushed annual inflation up to 13 percent in September from 5 percent at end-2006. The underlying rise in inflation has been more moderate, with inflation excluding food still below 51/2 percent (Figures 1 and 2).
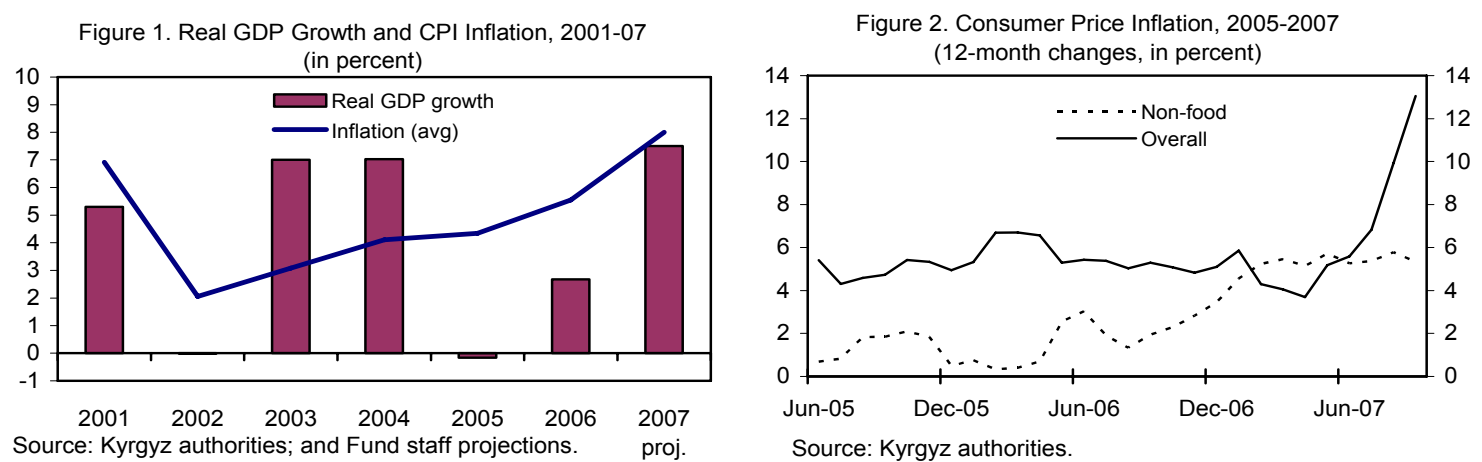

3. Foreign exchange inflows remain strong, apparently not much affected so far by the global credit squeeze. The current account deficit continued to widen during the first half of the year on account of higher imports driven by strong demand, but was more than financed by rising FDI and private capital inflows. Kazakh-owned banks in Kyrgyz Republic — which now account for about 50 percent of all outstanding loans - have been financing rapid credit expansion largely through borrowing from their parent banks. As Kazakh banks have themselves been badly hit by the recent global credit squeeze, these inflows are likely to decline. However, through end-September the overall balance of payments remained strong, with gross official reserves rising steadily to over $\$ 1$ billion.

\section{Helped by strong growth, fiscal performance has been much better than} expected. Buoyant receipts from import taxes and under execution of budgeted spending generated a fiscal surplus of about 2 percent of GDP at an annualized rate in the first half of the year. The Social Fund also registered a surge in revenues owing to recent wage increases and better compliance. The unanticipated revenue windfall prompted the 
authorities to introduce a supplementary budget that increased both revenue and expenditures by around 13/4 percent of GDP (including higher expenditures to finance the Shanghai Cooperation Organization summit and transfers to households affected by natural disasters). The targeted fiscal deficit for 2007 was kept unchanged, at 3.1 percent of GDP, in line with the program.

\section{Monetary policy has been expansionary for much of the year, but has been} tightened recently in response to the inflationary spike. The build up of government deposits as a result of fiscal overperformance allowed the central bank to meet the June target on net domestic assets, while conducting large unsterilized intervention to dampen appreciation pressures associated with continued strong foreign exchange inflows. As a result, reserve money growth rose, reaching 50 percent in the twelve months to endAugust, while the som was de facto pegged against the dollar from March (Figures 3 and 4). From mid-September, however, in response to the sharp rise in inflation in August, the central bank tightened policy markedly by raising interest rates on central bank bills and limiting intervention, allowing the som to appreciate by about 8 percent since end-August (Figure 5). Reserve money growth slowed to 40 percent by end-September, and there are now signs that credit growth is slowing, mostly as a result of the closing of credit lines from parent Kazakh banks which have been hit by the recent global credit squeeze. Total bank deposits and outstanding loans fell by 3-4 percent in the first three weeks of October.

Figure 3. Exchange Rate Developments, 2003-07
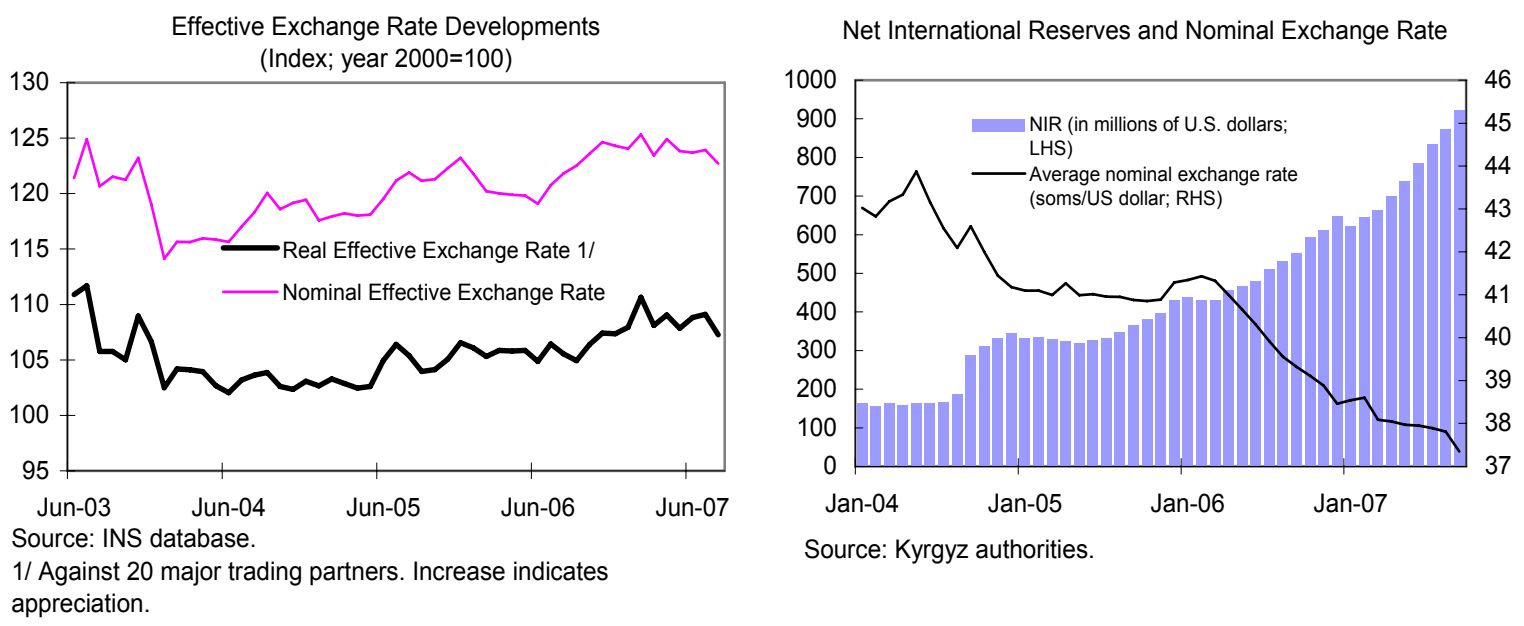

6. The PRGF-supported program is on track. All end-June performance criteria (PCs) were met with sizeable margins, although the indicative limits on reserve money and the electricity sector's quasi-fiscal-deficit (QFD) were missed (Table 1). Monetary policy is now back on track, following the recent correction of the overly loose stance. All structural benchmarks scheduled for end-June and end-September 2007 were met and the authorities are moving toward fulfillment of some of the missed end-December 2006 and end-March 2007 structural benchmarks, especially regarding the independent review of the NBKR's internal audit function, privatization of Agricultural Bank (formerly KAFC), and 
adoption of a new medium-term external debt management strategy. However, measures to introduce the new tax code and strengthen central bank autonomy remain stalled in parliament (Table 2).

Figure 4. Monetary Developments, 2006-07
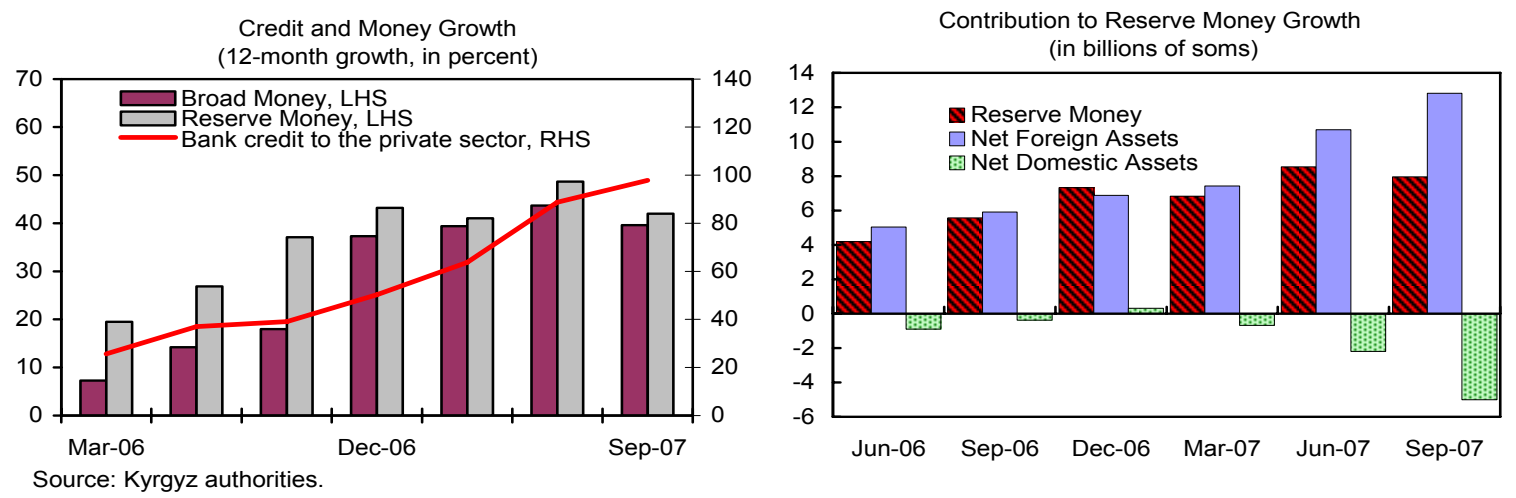

Figure 5. Interest Rate Developments, 2006-07
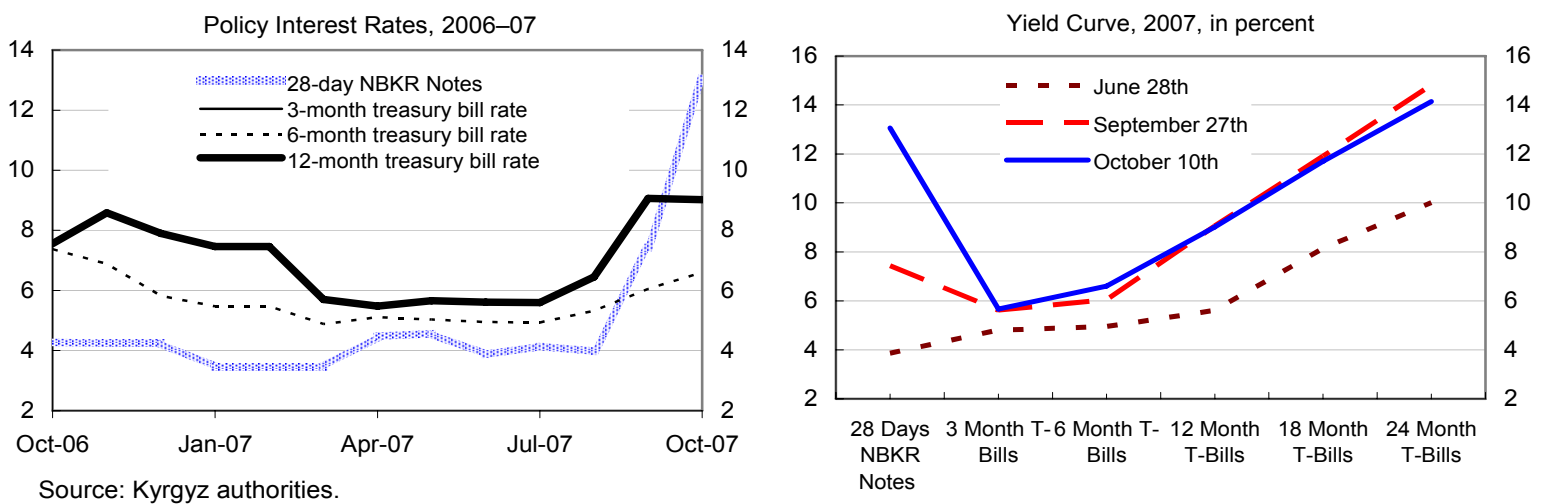

\section{Policy Discussions}

\section{A. Overview}

\section{Policy discussions focused on the challenges posed by the sharp uptick in} inflation in the context of exogenous shocks and global financial turbulence. While external price shocks have played a major part in the recent price surge, continued loose monetary conditions would risk entrenching high underlying inflation. The NBKR clearly recognizes the need to tighten monetary policy through restraining unsterilized intervention in the foreign exchange market and raising interest rates to facilitate the absorption of liquidity. In addition, the government intends to tighten the fiscal stance and improve monetary and fiscal policy coordination. The authorities' aim is to get inflation back down to single digits as quickly as possible, although their target of achieving this by 
end-2007 may be beyond reach, given the size of the external price shock since the mission completed its discussions.

8. The authorities' economic program for 2008 targets a further decline in inflation to around 7 percent. Real GDP growth is conservatively projected at 7 percent, premised on a recovery in gold output and buoyant growth in agriculture, construction and services. The monetary program assumes continued remonetization of the economy at a moderate pace. It limits reserve money growth to about 20 percent, consistent with broad money growth of 30 percent and a rise in official reserves to maintain end-year reserves coverage at around 4 months of projected imports. The external current account deficit is projected to narrow to 15 percent of GDP, from 18 percent in 2007, reflecting a recovery in gold exports and buoyant nongold exports and remittances (Table 3 ).

\section{B. Fiscal Issues}

9. The authorities plan to underexecute budgetary expenditures in 2007 and expect revenues to continue to exceed earlier projections. As a result, they expect the general government deficit to be $2 \frac{1}{4}$ percent of GDP, nearly 1 percentage point lower than the budget and program target. The authorities stressed that the political environment remained challenging, making it impossible to formally request sequestration of 2007 budgetary appropriations. Nevertheless, underspending in the first half of 2007 due to delays in budgetary approval would constrain the ability of spending agencies to fully execute the programmed expenditures. Staff agreed that continued fiscal restraint would make an important contribution to reversing the recent upturn in inflation. They noted that within the proposed spending envelope, reallocations would be needed to finance recent initiatives such as a 10 percent increase in pension benefits (accompanied by efforts to better target welfare recipients) starting October 1 and extraordinary purchases of fuel and grain to replenish government reserves (some 0.5 percent of GDP) (MEPq10) ${ }^{1}$.

10. The fiscal deficit in 2008 will be capped at around 2 percent of GDP, holding the fiscal stance broadly unchanged from the expected outcome in 2007 . The budget will be based on continued revenue gains ${ }^{2}$, consistent with a further small increase in the tax-to-GDP ratio (Table 4). Staff encouraged the authorities to take advantage of ongoing improvements in tax administration and compliance to start reducing cascading Road and Emergency taxes and further reduce the onerous payroll taxes from 27 percent to 25 percent, which they intend to do as part of 2009 budget. Staff also urged the authorities to secure prompt passage of the best-practice tax code before parliament, to underpin further improvements in tax administration (MEPף10).

11. Strong revenue performance and accelerating inflation have created pressures to raise wages and pension benefits. The draft 2008 budget envisages an average wage increase of 25-30 percent, to stem the exodus of qualified personnel and scale up social spending, raising the wage bill to over 25 percent of total expenditure. The mission advised

\footnotetext{
${ }^{1}$ Additional expenditures are due to higher wheat import prices to replenish stocks.

${ }^{2}$ The possible impact of the capital amnesty law is not included in the projections, as the authorities do not expect it to yield significant revenue.
} 
against future across-the-board wage increases and urged the authorities to launch, with the assistance of the World Bank, a civil service reform that could achieve their objectives while checking the upward drift of the wage bill (MEPq10).

12. The draft budget also includes an additional 10 percent increase in pension benefits from January 1. Pressures to raise pensions persist, as old age benefits are only one-third of the subsistence level. Staff advised authorities to target pension increases to the most vulnerable sectors, particularly given the additional burden imposed by parliament's decision, taken at the height of political tensions in March 2007, to reduce the retirement age, overturning a presidential veto. The government intends to submit a bill to parliament nullifying the law reducing the retirement age, to make room for higher pensions and payroll tax cuts (as recommended by staff). If the law is not repealed, the government will challenge it before the Constitutional Court, on the grounds that it constitutes an unfunded mandate. The mission advised the authorities to postpone premature plans to launch a mandatory fully-funded pension pillar and to focus on urgently needed reforms, with the assistance of the World Bank, including consolidation of the central government and social fund budgets (Table 7). The authorities now intend to introduce a fully-funded private pension fund within a few years after legal and financial safeguards are in place (MEPף11).

13. The government is committed to implementing further reforms to enhance public financial management (PFM). It has embarked upon a PFM action plan, prepared in consultation with donors, focusing on strengthening budget transparency and enhancing the tracking, monitoring, and reporting of poverty-related spending. The mission supported the authorities' plans to update the Medium-Term Budgetary Framework (MTBF) and urged them to ensure consistency between the 2008 annual budget and MTBF and actively use the MTBF in prioritizing expenditures (MEPq13) .

\section{Monetary Policy and Financial Sector Reforms}

14. The main burden of reducing inflation will be borne by monetary policy. The monetary program aims to slow reserve money growth from 40 percent (on a 12-month basis) in September to about 35 percent by end-2007 and 20 percent by end-2008. This will require exchange rate flexibility and limited intervention in the foreign exchange market, accompanied by stepped-up efforts to mop up liquidity by raising policy interest rates. With regard to the tightening of monetary policy that took place after the mission, the authorities intend to focus on clearer communication of policy intentions, to better guide market expectations. Passage of the bill to strengthen the NBKR's autonomy would help to support these efforts, but the authorities indicated that there was little prospect of approval by the present parliament (Tables 9 and10).

15. Political tensions between parliament and the government have delayed financial sector reforms. Despite delays, the NBKR continues to enhance supervision and has established a framework to assess market risks. It also has developed supervisory guidelines for Islamic Banking, and strengthened consolidated banking supervision. Furthermore, the NBKR has, in cooperation with the Financial Intelligence Service, developed reporting formalities to support implementation of the recently introduced antimoney laundering and counter terrorism financing (AML/CFT) law, and is working to 
bring these into conformity with the capital amnesty law (with the assistance from a TA by LEG) (MEP 15,16$)$. Notwithstanding progress in these areas, a large reform agenda remains. This includes the completion of missed end-December 2006 and end-March 2007 structural benchmarks and continued vigilance to detect banking sector weaknesses, particularly in the context of the recent international liquidity squeeze and the associated problems being faced by Kazakh banks.

\section{External Sector}

\section{Recent analysis points to an upgrade in the debt burden classification for}

Kyrgyz Republic. The joint debt sustainability analysis (DSA) undertaken by Fund and World Bank staffs (Annex I) suggests — based on the latest available debt indicators and favorable medium-term outlook - a reclassification of the risk of debt distress to moderate, from high in 2006. Debt indicators are now well below HIPC eligibility thresholds, reflecting the recent strong economic recovery, as well as continued prudent debt management and fiscal consolidation. Nonetheless, recognizing that the debt outlook will remain vulnerable to exogenous shocks or policy reversals, the authorities intend to continue refraining from nonconcessional external borrowing or guarantees. They noted that their updated external debt management strategy (expected to be implemented shortly) would maintain the 45 percent minimum grant element on any new public borrowing, strengthen risk assessment of external loans, and tighten supervision of external borrowing by public enterprises (MEPף17).

\section{Official statistics seriously overestimate the external current account deficit.}

Staff, with the agreement of authorities, has made adjustments in the balance of payments to account for "missing" re-exports of consumer goods to neighboring countries. Preliminary calculations suggest that the figure could have amounted to about $\$ 200$ million (7 percent of GDP) in 2006 and will likely exceed $\$ 300$ million in 2007. Current account deficit estimates have been revised accordingly (Table 11).

\section{E. Other Issues}

\section{Progress in reducing the electricity sector's QFD has been slow. Staff} encouraged the authorities to continue reforming the sector to ensure a rapid and financially viable increase in power supplies to domestic and regional markets. Though the action plan prepared with the assistance of World Bank is on hold, parliament has approved the construction of two new hydroelectric power generation stations, with private sector participation. The staff recommended early approval of the medium-term electricity tariff policy, which envisages increases in electricity prices, starting in spring 2008, to cost recovery levels by 2010. However, eventual elimination of the QFD will also require supporting steps to strengthen utility bill collections, reduce technical losses and theft, and increase private participation in the distribution utilities ${ }^{3}$ (MEPq18).

\footnotetext{
${ }^{3}$ The QFD is not directly financed by the budget, but results in inadequate capital investment and maintenance in the energy sector. This represents a potential future liability for the government.
} 
19. The government has reached agreement with the Canadian Cameco/Centerra consortium - owner of the key Kumtor gold mine — on a modified investment agreement. After approval by parliament, the government will receive an additional $\$ 300$ million of equity in Centerra. In return, Centerra will get a simplified flat tax regime for the gold sector and additional areas for exploration. The proposed Kazakh-Kyrgyz investment fund and the development fund (DF) approved earlier, to be partly financed from the proceeds of Centerra share sales, remain on hold. The staff reiterated its earlier recommendation that the DF should be fully transparent and included in the budget. Staff also advised the authorities to phase in DF operations gradually, in light of the ongoing rapid increase in liquidity and inflationary pressures.

\section{StAfF Appraisal}

20. Performance under the PRGF-supported program has generally been good. GDP is recovering rapidly, all end-June performance criteria have been met, and, in a calmer political environment, progress has resumed on structural reforms. Economic recovery, combined with firm fiscal discipline, has improved the country's debt indicators. The main challenge for the authorities is to sustain the recovery by building further reform momentum, while preventing the recent upsurge in inflation from becoming entrenched.

21. Tighter monetary policy is needed to contain inflation. While higher international wheat prices have added greatly to inflationary pressures recently, underlying inflation has been rising over the past year as the central bank has persisted with unsterilized intervention to resist exchange rate appreciation. The change of policy direction since mid-September, with higher interest rates, more limited intervention, and an appreciation of the exchange rate, is a welcome recognition by the central bank that a tighter monetary stance is needed. Clear communication of the new strategy will help to better guide market expectations and maintain political support.

\section{Continued fiscal restraint is important both for reducing inflation and for} enhancing debt sustainability. Revenue performance this year has been impressive, but the temptation to ramp up spending in response should be resisted. The authorities' commitment to undershoot the program's fiscal deficit target for 2007 will provide necessary support to monetary policy in dampening the current inflationary pressures. The draft 2008 budget sets an adequate deficit target, although a somewhat tighter stance would help to stem inflationary pressures and reduce the large current account deficit. The government needs to forestall the upward drift in current spending by refraining, in the future, from across the board public wage increases and moving forward with a broad civil service reform. In the face of expenditure pressures, it will be particularly important to further strengthen tax administration, especially by securing prompt passage of the new tax code prepared with the assistance of FAD TA. Repeal of the retirement age reduction and comprehensive pension reform, with World Bank assistance, will be needed to secure medium-term fiscal sustainability.

23. Encouraging progress has been made in "growing out of the debt problem," following the authorities' decision earlier this year not to pursue debt relief under HIPC. Further progress will be helped by firm adherence to the program commitment not to contract or guarantee nonconcessional external debt, as well as by early adoption of the 
new medium-term debt management strategy. As the debt burden remains high, structural reforms to sustain growth and promote economic diversification will be important to reduce the economy's vulnerability to external shocks.

24. Vigilance is needed regarding potential banking sector weaknesses. While the central bank has continued to strengthen supervision, every effort should be made to press ahead with measures - including several delayed structural benchmarks - to reform the financial sector and enhance the NBKR's autonomy. The authorities should watch closely for signs of contagion from banking sector problems in neighboring Kazakhstan. While the impact is limited so far, Kyrgyz banks are unlikely to remain unaffected if the global credit squeeze persists.

\section{Progress on the broader reform agenda will hinge on the maintenance of} political stability. Resolution of constitutional issues should allow for closer cooperation between government and parliament in advancing critical reforms in the energy sector, as well as measures to foster good governance and transparency in public sector operations, as set out in the authorities' Country Development Strategy. The settlement of the dispute with the owners of the Kumtor gold mine - and the resulting removal of the threat of renationalization - is a welcome step that should help to improve the business climate. Careful use of the additional resources now available - including by ensuring that any additional spending is at a measured pace, transparent, and through the budget - would help to finance a sustainable improvement in infrastructure and the social safety net.

26. Staff recommends completion of the $5^{\text {th }}$ review under the PRGF arrangement. Continued compliance with the program's quantitative performance targets, the policy response to the recent uptick in inflation, and an improving political environment for reform all suggest that risks remain manageable. Staff welcomes the authorities' interest in maintaining close relations with the Fund and looks forward to discussing modalities for engagement with the Fund after expiry of the current PRGF arrangement early next year. To permit Board consideration of the $6^{\text {th }}$ review and disbursement of final tranche, staff supports the authorities' request for an extension of the existing arrangement (expiring on March 14, 2008) to May 31, 2008. 


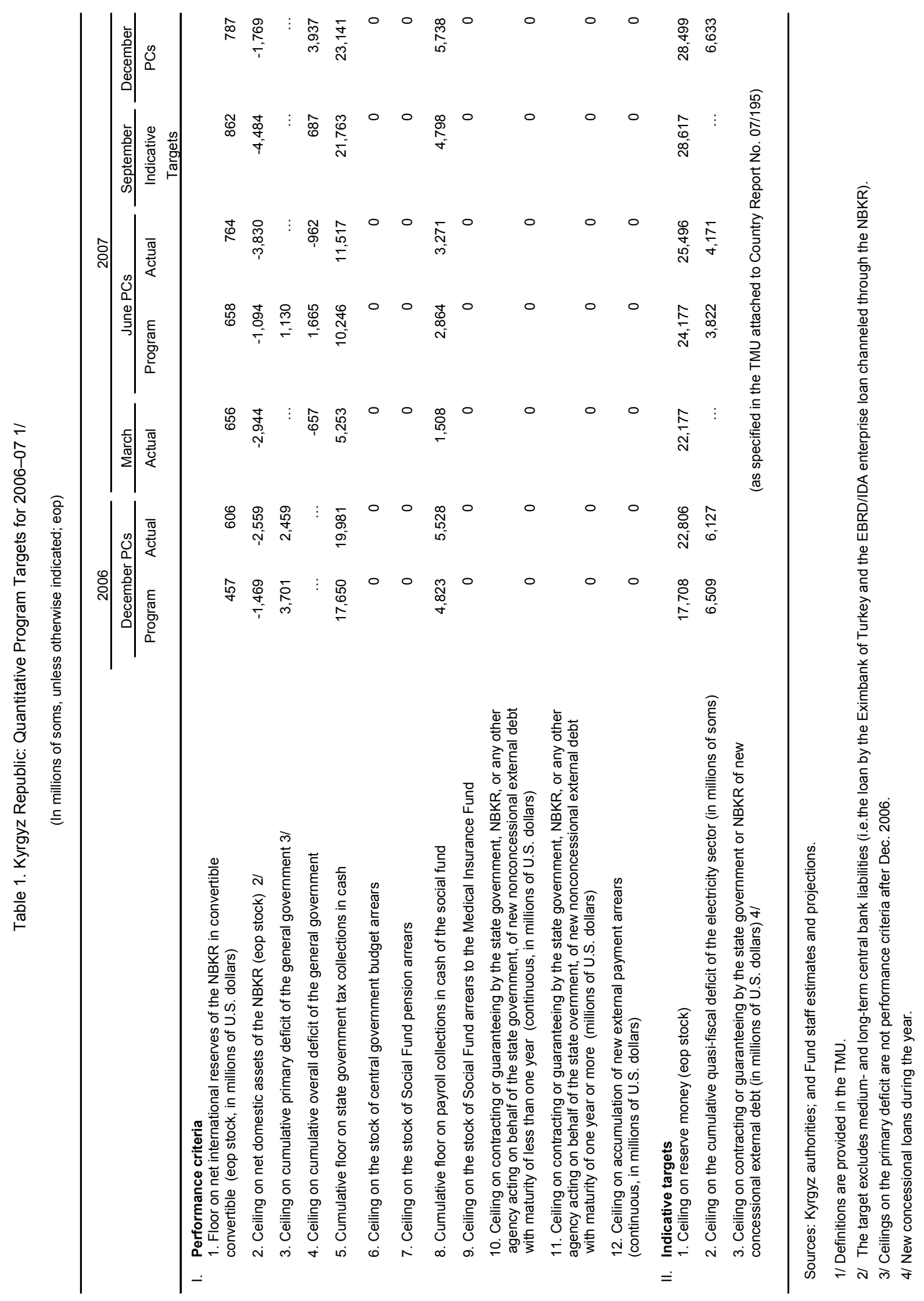




\section{Table 2. Kyrgyz Republic: Structural Conditionality, 2006-07}

\section{September-December 2006}

\section{Structural benchmarks for end-September 2006}

- Prepare an action plan to reduce the energy sector's quasi-fiscal deficit in close cooperation with World Bank staff, addressing problems of transmission and distribution losses, payment indiscipline, and tariff adjustment. [Observed]

- Expand the operation of the Large Taxpayers Unit to cover at least 60 percent of tax revenues. [Observed]

\section{Structural benchmarks for end-December 2006}

- Conduct an independent review of the NBKR's internal audit function. The review could be performed by the internal audit department of another central bank, and should include a review of the capacity of the NBKR's internal audit division, as recommended by the Safeguards Assessment Report conducted by Finance Department in 2005. [Not observed]

- Bring KAFC to the point of sale and issue a privatization tender for the company. [Not observed]

- Submit to IMF staff a report prepared by the ministry of labor and social protection recommending measures to improve labor market flexibility. [Observed]

- Secure approval of legislation that has been already sent to parliament to enhance the NBKR's legal independence and ensure legal protection of its employees in performing official duties. [Not observed]

\section{March-December 2007}

\section{Structural benchmarks for end-March 2007}

- The government will submit to parliament amendments (drafted by the NBKR) to the civil, housing and land codes, as well as to all the laws governing collateral, in order to harmonize provisions on collateralized lending by financial institutions and facilitate collateral seizure in cases of default. [Not observed]

- Approval of the tax code bill that is before parliament. [Not observed]

- The government will adopt a new medium-term external debt management strategy aimed at ensuring external debt sustainability, as described in paragraph 24 of the MEP for the third review under the arrangement. [Not observed]

\section{Structural benchmarks for end-June 2007}

- The NBKR will implement regulations for consolidated supervision to monitor risks faced by financial institutions, in line with the recommendations of the 2005 Basel Core Principles for Effective Banking Supervision Assessment. [Observed]

- The government will introduce a new and detailed budget classification, based on the best practice reporting of government finances (GFS 2001), which will permit monitoring of poverty reducing expenditures in the monthly budget execution reports. [Observed] 


\section{Table 2 (Concluded). Kyrgyz Republic: Structural Conditionality, 2006-07}

\section{Structural benchmarks for end-September 2007}

- Submit to IMF staff a written Memorandum of Understanding agreed between the NBKR and the State Agency for Financial Supervision and Reporting (SAFSR), delineating the specific supervisory responsibilities of the SAFSR and establishing modalities for information-sharing between them, as recommended by the FSAP update mission. [Observed]

- Submit to parliament an internal audit law for government agencies in line with best international audit practices, in order to establish an appropriate framework for internal public sector controls. [Observed]

\section{Structural benchmarks for end-December 2007}

- To ensure finality of bank resolution, the government and the NBKR will secure parliamentary approval of further amendments to the bank bankruptcy law modifying the provisions introduced in September 2006, which allowed reinstatement of banks that are insolvent and in the process of liquidation.

- Submit to IMF staff a best-practice, time-bound action plan to modernize customs administration, including greater selectivity of customs control based on risk criteria and expanding post-clearance audits.

- Submit to parliament enabling legislation to enhance flexibility in the use of bank accounts (including demand deposits) for settlement purposes by legal entities and physical persons. 
Table 3. Kyrgyz Republic: Selected Economic Indicators, 2005-08

\begin{tabular}{|c|c|c|c|c|c|c|}
\hline & \multirow{2}{*}{$\frac{2005}{\text { Act. }}$} & 2006 & \multicolumn{2}{|c|}{2007} & \multicolumn{2}{|c|}{2008} \\
\hline & & Act. & IMF/CR/07/195 & Proj. & IMF/CR/07/195 & Proj. \\
\hline Nominal GDP (in billions of soms) & 100.9 & 113.2 & 126.6 & 130.8 & 140.4 & 150.4 \\
\hline Nominal GDP (in millions of U.S. dollars) & 2,460 & 2,822 & 3,287 & 3,488 & 3,646 & 4,066 \\
\hline Real GDP (growth in percent) & -0.2 & 2.7 & 6.5 & 7.5 & 6.6 & 7.0 \\
\hline GDP per capita (in U.S. dollars) & 478.2 & 541.6 & 624.3 & 663.4 & 685.3 & 764.9 \\
\hline Consumer prices (percent change, eop) & 4.9 & 5.1 & 5.0 & 8.5 & 4.0 & 7.0 \\
\hline Consumer prices (percent change, average) & 4.3 & 5.6 & 5.0 & 8.0 & 4.0 & 7.0 \\
\hline Producer prices (percent change, eop) & 6.0 & 10.4 & $\ldots$ & $\ldots$ & $\ldots$ & $\ldots$ \\
\hline Producer prices (percent change, average) & 2.6 & 15.3 & $\ldots$ & $\ldots$ & $\ldots$ & $\ldots$ \\
\hline \multicolumn{7}{|l|}{ Investment and savings (in percent of GDP) $1 /$} \\
\hline Investment & 21.8 & 23.4 & 23.6 & 23.0 & 24.6 & 23.0 \\
\hline Public & 4.8 & 4.3 & 5.6 & 5.5 & 5.8 & 5.3 \\
\hline Private & 17.0 & 19.0 & 18.0 & 17.5 & 18.8 & 17.7 \\
\hline Savings & 25.0 & 16.4 & 11.0 & 5.1 & 13.8 & 7.8 \\
\hline Public & 0.6 & 2.0 & 2.1 & 3.0 & 2.8 & 3.1 \\
\hline Private & 24.4 & 14.4 & 8.9 & 2.1 & 11.0 & 4.7 \\
\hline Savings-investment balance & 3.2 & -6.6 & -12.6 & -17.9 & -10.8 & -15.1 \\
\hline \multicolumn{7}{|l|}{ General government finances (in percent of GDP) 1/ $2 /$} \\
\hline Total revenue and grants & 24.7 & 26.6 & 27.6 & 30.1 & 28.2 & 29.9 \\
\hline of which: Tax revenue & 20.0 & 21.5 & 21.6 & 23.5 & 21.5 & 23.8 \\
\hline Total expenditure (including net lending) & 28.4 & 28.7 & 30.7 & 32.3 & 30.6 & 31.9 \\
\hline of which: Current expenditure & 24.1 & 24.5 & 25.6 & 27.1 & 25.3 & 26.8 \\
\hline Capital expenditure & 4.8 & 4.3 & 5.6 & 5.5 & 5.8 & 5.5 \\
\hline Overall fiscal balance & -3.7 & -2.1 & -3.1 & -2.2 & -2.5 & -2.0 \\
\hline Primary balance & -2.2 & -1.2 & -2.1 & -1.3 & -4.0 & -1.2 \\
\hline \multicolumn{7}{|l|}{ Banking sector $3 /$} \\
\hline Net foreign assets (percent change, eop) & 20.1 & 47.6 & 28.0 & 28.7 & 3.6 & 23.3 \\
\hline Net domestic assets (percent change, eop) & 54.5 & 65.0 & 37.6 & 97.9 & 112.8 & 41.6 \\
\hline Credit to private sector (in percent of GDP) & 8.0 & 10.4 & 11.8 & 16.1 & 16.6 & 16.3 \\
\hline Broad money (percent change, eop) & 25.5 & 51.0 & 30.0 & 43.4 & 28.2 & 28.7 \\
\hline Velocity of broad money $4 /$ & 4.7 & 3.5 & 3.0 & 2.8 & 2.6 & 2.5 \\
\hline Interest rate $5 /$ & 25.7 & 25.7 & $\ldots$ & $\ldots$ & $\ldots$ & $\ldots$ \\
\hline \multicolumn{7}{|l|}{ External sector } \\
\hline Current account balance (in percent of GDP) $1 /$ & 3.2 & -6.6 & -12.6 & -17.9 & -10.8 & -15.1 \\
\hline Export of goods and services (million USD) & 1,050 & 1,385 & 1,419 & 1,903 & 1,636 & 2,286 \\
\hline Export growth (percent change) & 3 & 32 & 23 & 37 & 15 & 20 \\
\hline Import of goods and services (million USD) & 1,397 & 2,253 & 2,535 & 3,379 & 2,823 & 3,771 \\
\hline Import growth (percent change) & 24 & 61 & 14 & 50 & 11 & 12 \\
\hline Gross official reserves (million USD) 6/ & 609 & 817 & 937 & 1,053 & 1,067 & 1,233 \\
\hline Gross reserves (months of imports, eop) & 3.2 & 2.9 & 4.0 & 3.4 & 4.2 & 3.8 \\
\hline External public debt outstanding (in percent of GDP) & 78.0 & 70.2 & 61.0 & 57.7 & 56.3 & 50.5 \\
\hline Debt service-to-export ratio (in percent) & 6.5 & 3.5 & 5.2 & 3.5 & 4.4 & 3.5 \\
\hline \multicolumn{7}{|l|}{ Memorandum items } \\
\hline Exchange rate (soms per U.S. dollar, average) & 41.0 & 40.1 & $\ldots$ & $\ldots$ & $\ldots$ & $\ldots$ \\
\hline Real effective exchange rate $(2000=100)$ (average) & 104.5 & 106.1 & $\ldots$ & $\ldots$ & $\ldots$ & $\ldots$ \\
\hline
\end{tabular}

Sources: Kyrgyz authorities; and Fund staff estimates and projections.

1/ The authorities are continuing to revise the historical external current account data, but at this point, there is a break in the series in 2006 . 2/ General government comprises state government and Social Fund finances. State government comprises central and local governments. $3 /$ Projections are based on program exchange rates specified in the Technical Memorandum of Understanding (TMU). 4/ 12-month GDP over end-period broad money.

$5 /$ Weighted average interest rate on som-denominated loans.

6/ Gross reserves exclude international reserves of the NBKR that are pledged or blocked. 


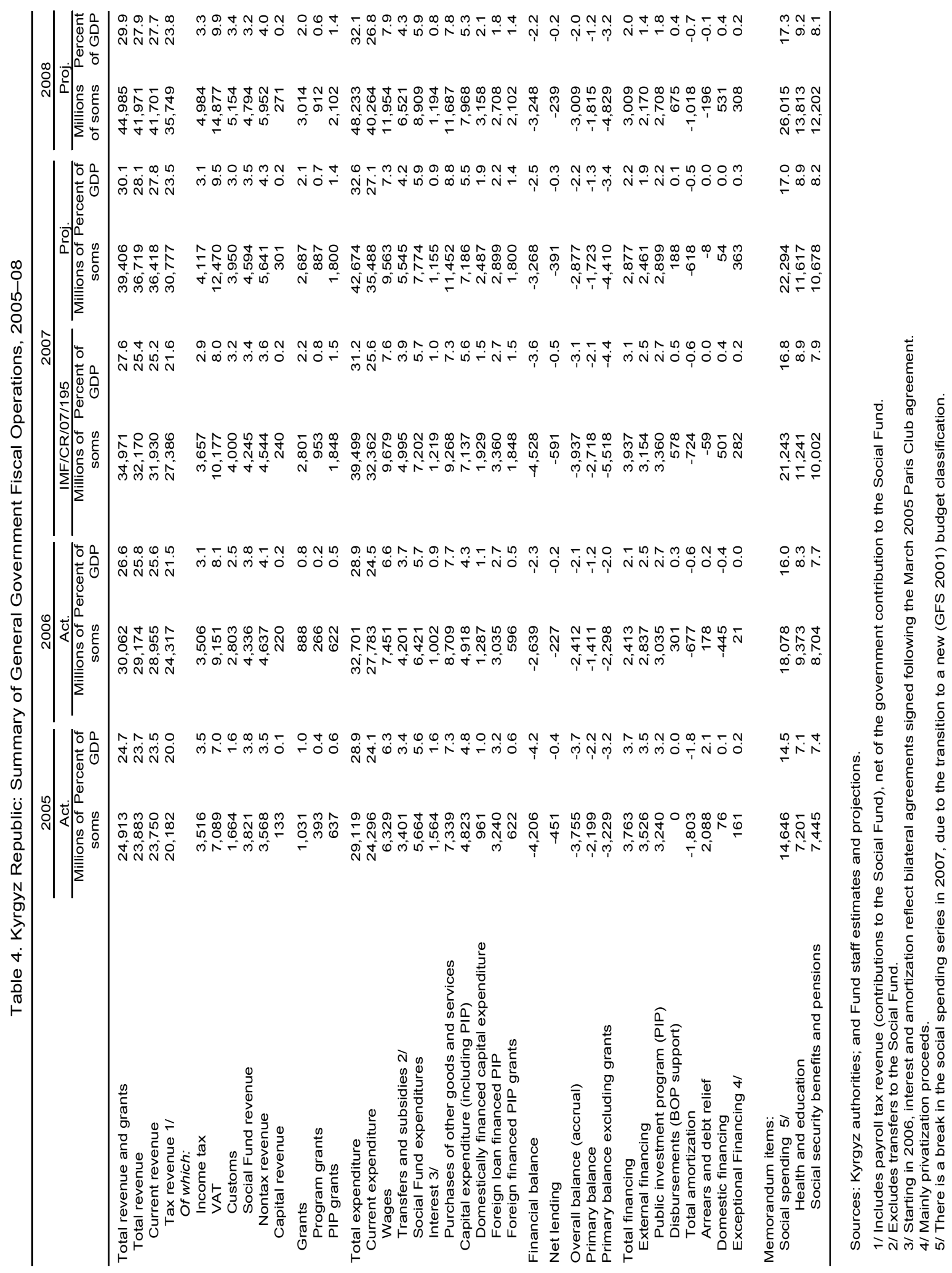


Table 5. Kyrgyz Republic: General Government Finances, 2005-08

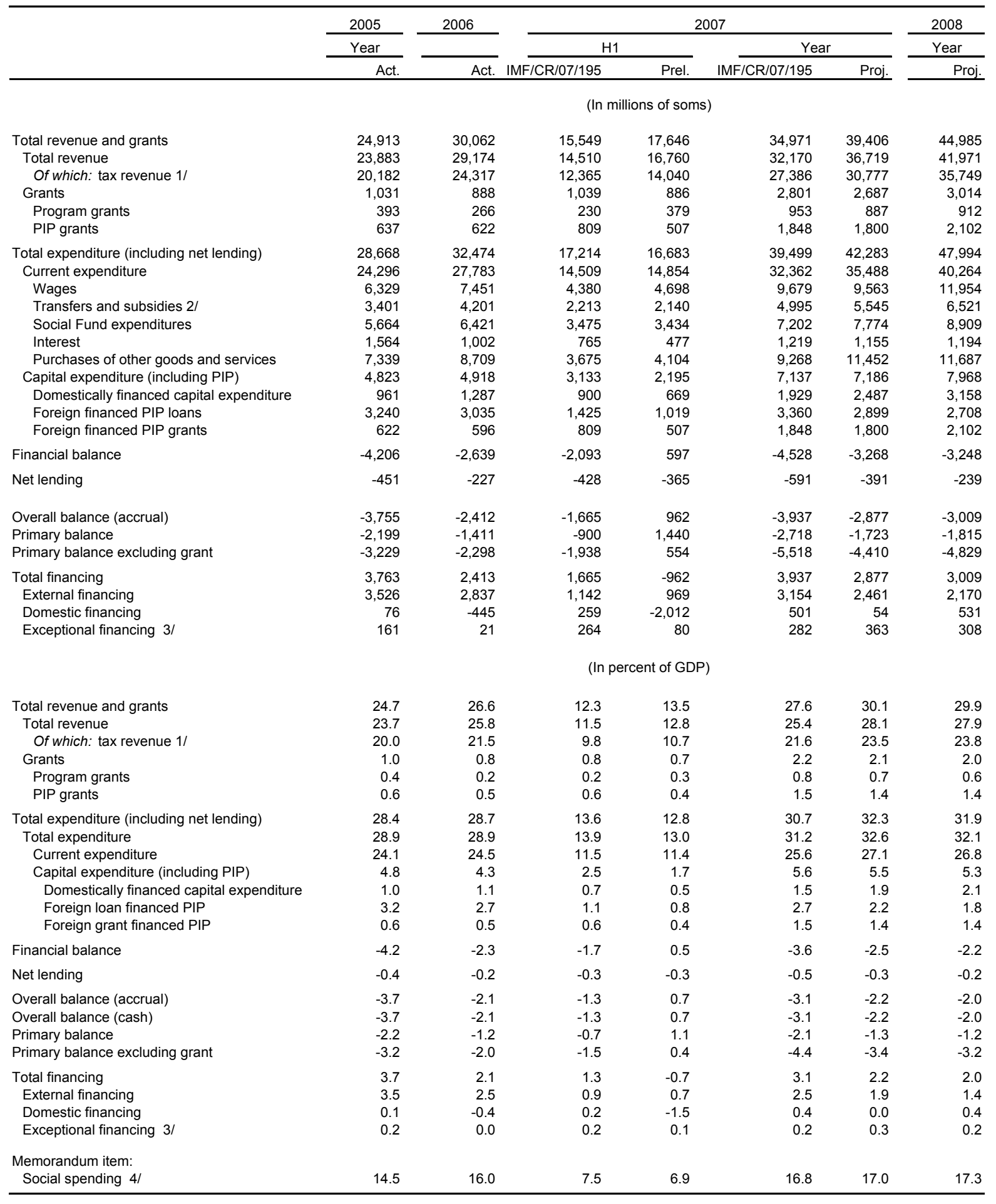

Sources: Kyrgyz authorities; and Fund staff estimates and projections.

1 / Includes payroll tax revenue (contribution to the Social Fund), net of the government contribution to the Social Fund.

2/ Excludes transfers to the Social Fund.

$3 /$ Mainly privatization proceeds.

4/ There is a break in the social spending series in 2007, due to the transition to a new (GFS 2001) budget classification. 
Table 6. Kyrgyz Republic: State Government Finances, 2005-08

(In millions of soms)

\begin{tabular}{|c|c|c|c|c|c|c|c|c|}
\hline & \multirow{3}{*}{$\begin{array}{l}2005 \\
\text { Year } \\
\text { Act. }\end{array}$} & \multirow{2}{*}{\multicolumn{2}{|c|}{$\frac{2006}{\text { Year }}$}} & \multicolumn{4}{|c|}{2007} & \multirow{3}{*}{$\begin{array}{c}2008 \\
\text { Year } \\
\text { Proj }\end{array}$} \\
\hline & & & & IMF/CR/07/195 & $\mathrm{H} 1$ & IMF/CR/07/195 & $\begin{array}{l}\text { Year } \\
\end{array}$ & \\
\hline & & IMF/CR/06/235 & $\overline{\text { Act. }}$ & & & & Proj. & \\
\hline Total revenue and grants & 21,006 & 22,886 & 25,644 & 13,391 & 15,054 & 30,646 & 34,700 & 40,062 \\
\hline Total revenue & 19,975 & 21,731 & 24,756 & 12,352 & 14,167 & 27,845 & 32,013 & 37,049 \\
\hline Current revenue & 19,929 & 21,663 & 24,618 & 12,301 & 14,091 & 27,685 & 31,824 & 36,907 \\
\hline Tax revenue & 16,361 & 17,650 & 19,981 & 10,246 & 11,517 & 23,141 & 26,183 & 30,955 \\
\hline Income tax & 3,516 & 3,065 & 3,506 & 1,742 & 2,027 & 3,657 & 4,117 & 4,984 \\
\hline VAT $1 /$ & 7,089 & 7,721 & 9,151 & 4,406 & 5,379 & 10,177 & 12,470 & 14,877 \\
\hline Excises & 1,150 & 1,379 & 1,205 & 681 & 680 & 1,437 & 1,488 & 1,642 \\
\hline Customs & 1,664 & 1,978 & 2,803 & 1,715 & 1,540 & 4,000 & 3,950 & 5,154 \\
\hline Land tax & 319 & 559 & 412 & 184 & 237 & 567 & 570 & 655 \\
\hline Road tax and Emergency Fund & 1,410 & 1,550 & 1,534 & 763 & 851 & 1,686 & 1,724 & 1,315 \\
\hline Retail sales tax & 605 & 675 & 772 & 406 & 488 & 885 & 1,056 & 1,139 \\
\hline Other $2 /$ & 610 & 724 & 599 & 349 & 315 & 732 & 809 & 1,188 \\
\hline Nontax revenue & 3,568 & 4,014 & 4,637 & 2,054 & 2,575 & 4,544 & 5,641 & 5,952 \\
\hline Capital revenue & 46 & 68 & 138 & 51 & 76 & 160 & 189 & 142 \\
\hline Grants & 1,031 & 1,155 & 888 & 1,039 & 886 & 2,801 & 2,687 & 3,014 \\
\hline Program grants & 393 & $\ldots$ & 266 & 230 & 379 & 953 & 887 & 912 \\
\hline PIP grants & 637 & $\ldots$ & 622 & 809 & 507 & 1,848 & 1,800 & 2,102 \\
\hline Total expenditure (excluding net lending) & 25,601 & 26,645 & 28,787 & 15,629 & 15,048 & 35,224 & 37,977 & 43,310 \\
\hline Current expenditure & 20,778 & 21,795 & 23,869 & 12,496 & 12,853 & 28,087 & 30,791 & 35,342 \\
\hline Wages and Social Fund contributions & 7,484 & 8,150 & 8,699 & 5,155 & 5,465 & 11,230 & 11,219 & 13,974 \\
\hline Transfers and subsidies $3 /$ & 3,401 & 4,173 & 4,201 & 2,213 & 2,140 & 4,995 & 5,545 & 6,521 \\
\hline Transfers to Social Fund & 982 & 1,038 & 1,257 & 688 & 662 & 1,375 & 1,419 & 1,965 \\
\hline Interest & 1,564 & 928 & 1,002 & 765 & 477 & 1,219 & 1,155 & 1,194 \\
\hline Purchases of other goods and services $4 /$ & 7,339 & 7,506 & 8,709 & 3,675 & 4,104 & 9,268 & 11,452 & 11,687 \\
\hline Capital expenditure (including PIP) & 4,823 & 4,850 & 4,918 & 3,133 & 2,195 & 7,137 & 7,186 & 7,968 \\
\hline Domestically financed capital expenditure & 961 & 1,393 & 1,287 & 900 & 669 & 1,929 & 2,487 & 3,158 \\
\hline $\begin{array}{l}\text { Foreign-financed PIP } \\
\text { Foreign grant financed PIP }\end{array}$ & $\begin{array}{r}3,240 \\
622\end{array}$ & 3,457 & $\begin{array}{r}3,035 \\
596\end{array}$ & $\begin{array}{r}1,425 \\
809\end{array}$ & $\begin{array}{r}1,019 \\
507\end{array}$ & $\begin{array}{l}3,360 \\
1,848\end{array}$ & $\begin{array}{l}2,899 \\
1,800\end{array}$ & $\begin{array}{l}2,708 \\
2,102\end{array}$ \\
\hline Financial balance & $-4,595$ & $-3,759$ & $-3,143$ & $-2,238$ & 6 & $-4,578$ & $-3,276$ & $-3,248$ \\
\hline Net lending & -451 & -354 & -227 & -428 & -365 & -591 & -391 & -239 \\
\hline Primary balance excluding grants & $-3,610$ & $-3,632$ & $-2,801$ & $-2,083$ & -38 & $-5,568$ & $-4,410$ & $-4,829$ \\
\hline Primary balance & $-2,580$ & $-2,477$ & $-1,913$ & $-1,045$ & 848 & $-2,767$ & $-1,723$ & $-1,815$ \\
\hline Accrual surplus (+) / deficit (-) & $-4,144$ & $-3,404$ & $-2,915$ & $-1,810$ & 371 & $-3,987$ & $-2,877$ & $-3,009$ \\
\hline Total financing & 4,144 & 3,404 & 2,915 & 1,810 & -371 & 3,987 & 2,877 & 3,009 \\
\hline External financing & 3,526 & 3,681 & 2,837 & 1,142 & 969 & 3,154 & 2,461 & 2,170 \\
\hline Public investment program (PIP) & 3,240 & 3,457 & 3,035 & 1,425 & 1,019 & 3,360 & 2,899 & 2,708 \\
\hline Disbursements (BOP support) & 0 & 748 & 301 & 193 & 188 & 578 & 188 & 675 \\
\hline Total amortization & $-1,803$ & -523 & -677 & -348 & -298 & -724 & -618 & $-1,018$ \\
\hline Arrears and rescheduling & 2,088 & 0 & 178 & -126 & 61 & -59 & -8 & -196 \\
\hline Domestic financing & 457 & -564 & 58 & 404 & $-1,420$ & 551 & 54 & 531 \\
\hline Exceptional Financing 5/ & 161 & 287 & 21 & 264 & 80 & 282 & 363 & 308 \\
\hline
\end{tabular}

Sources: Kyrgyz authorities; and Fund staff estimates and projections.

$1 /$ In 2005, the VAT and customs revenues were reclassified, leading to lower VAT and higher customs duty collections.

2/ Mainly mineral resource tax and motor vehicle tax.

3/ Excludes transfers to Social Fund (columns for original program include transfer to Social Fund).

4/ Includes carry-forward expenditure from previous fiscal year (som 994 million in 2004, som 945 million in 2005, and som 480 million in 2006).

5/ Mainly privatization proceeds. 
Table 7. Kyrgyz Republic: Social Fund Operations, 2005-08

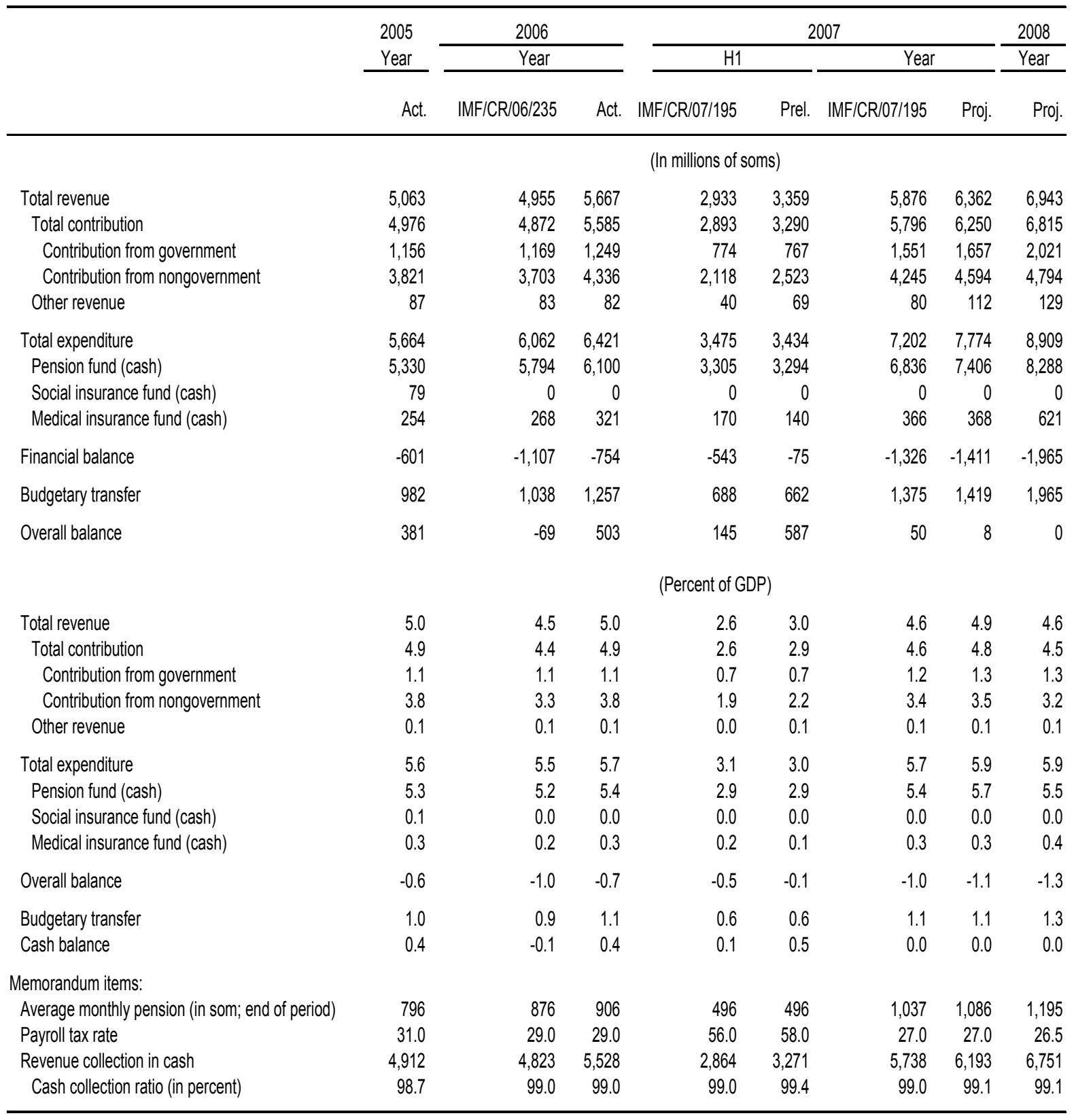

Sources: Kyrgyz authorities; and Fund staff estimates and projections. 
Table 8. Kyrgyz Republic: Medium-Term Expenditure Framework for General Government by Functional Classification, 2005-09

(In percent of GDP)

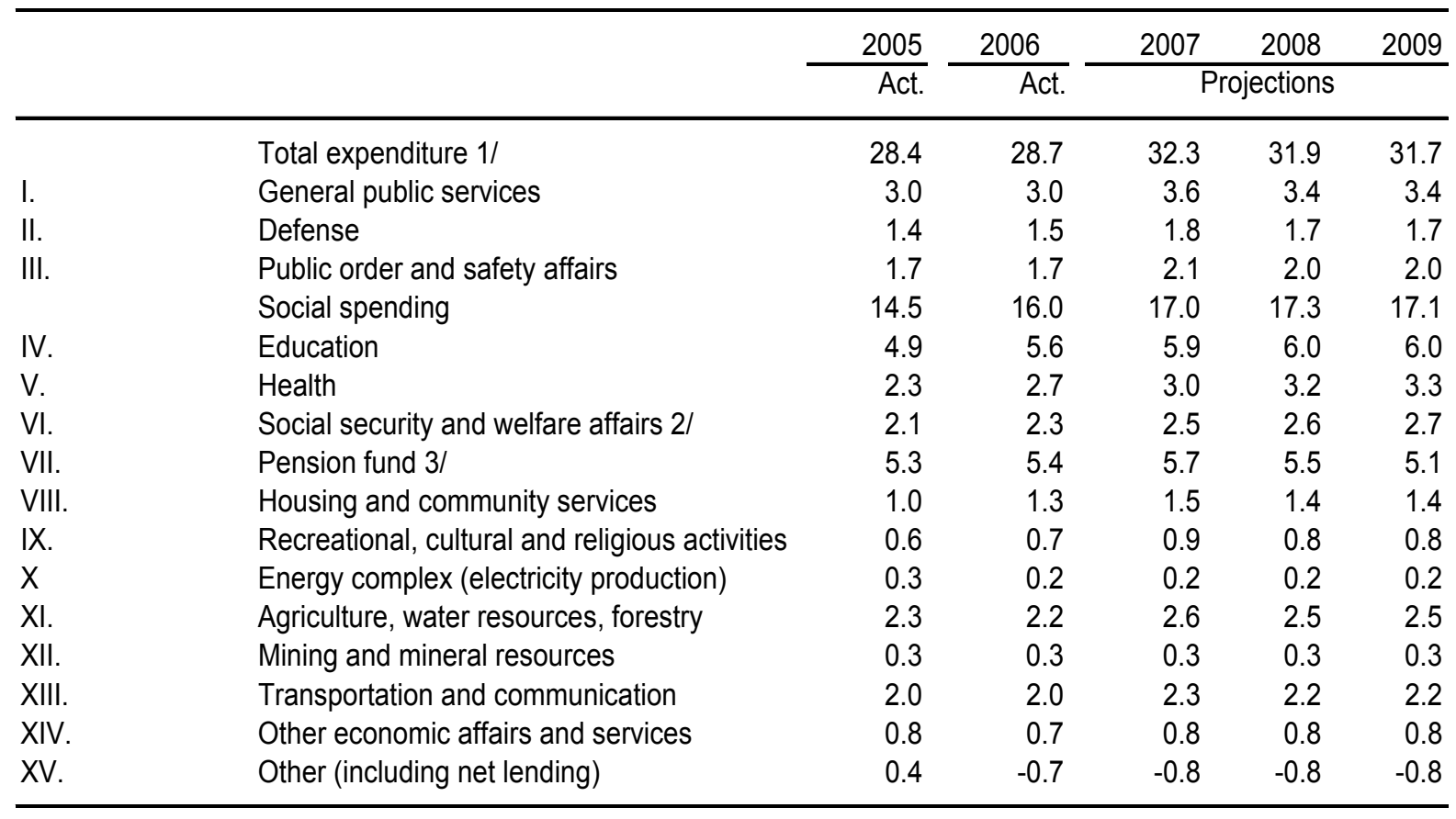

Sources: Kyrgyz authorities; and Fund staff estimates and projections.

1/ Including PIP and net lending.

2/ Excluding net transfers to the Social Fund, but including the contingency item for social compensation in case of electricity tariff increases.

3 / Social Fund operations net of transfers to other funds. 
Table 9. Kyrgyz Republic: NBKR Accounts, 2005-08

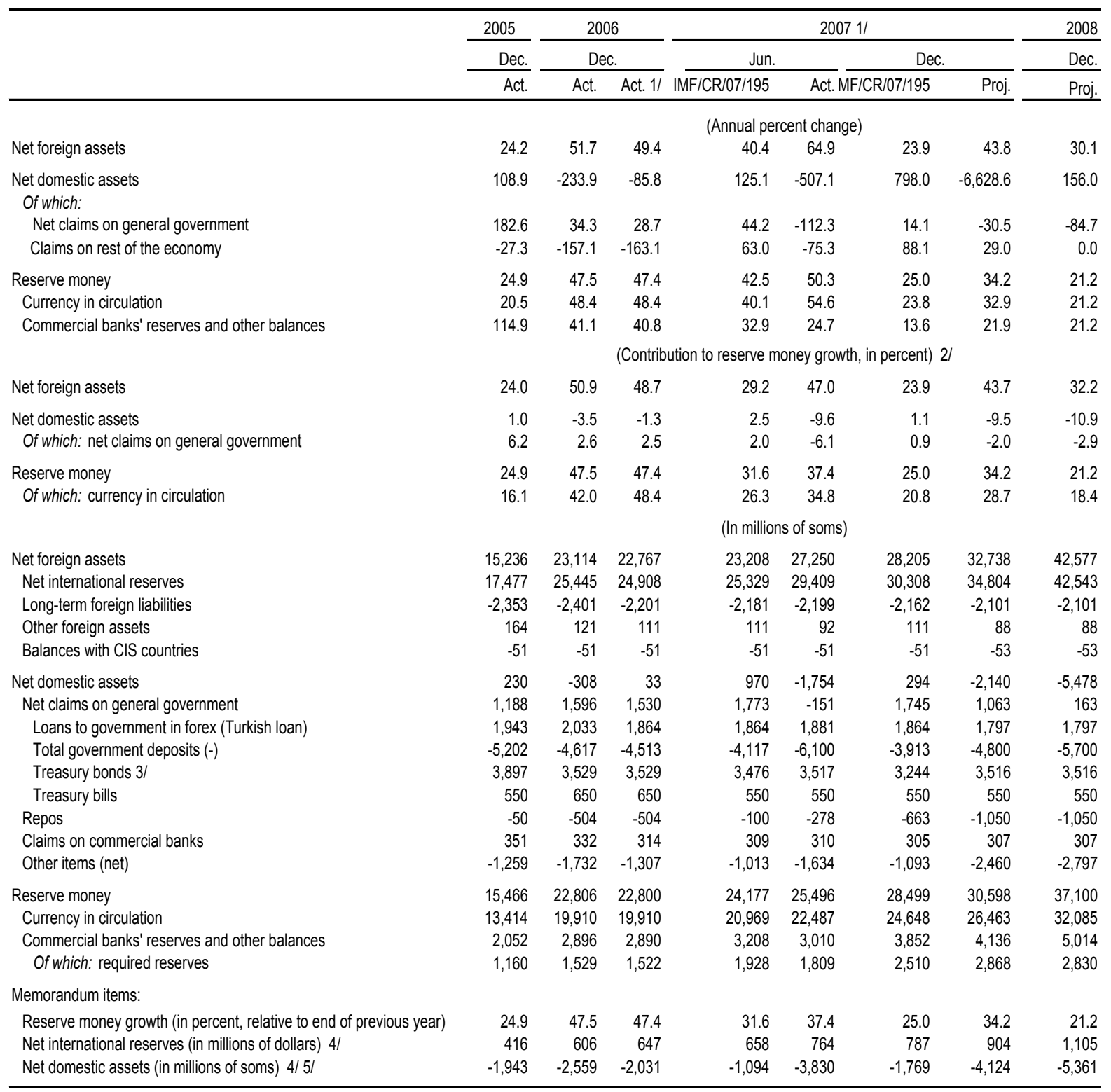

Sources: Kyrgyz authorities; and Fund staff estimates.

1/ Based on new program exchange rates (including 38.5 soms/dollar) specified in the TMU.

2/ Contribution is defined as annual change of asset stock relative to previous year's reserve money stock (in percent).

3/ Includes government securities issued in December 2002 to replace restructured bonds, as well as those issued for revaluation losses, lost capital in the

Asian Development Bank, and capitalized past interest arrears on bonds.

4/ Non-adjusted.

5/ Excludes medium- and long-term central bank liabilities (i.e.the loan by the Eximbank of Turkey and the EBRD/IDA enterprise loan channeled through the NBKR). 
Table 10. Kyrgyz Republic: Monetary Survey, 2005-08

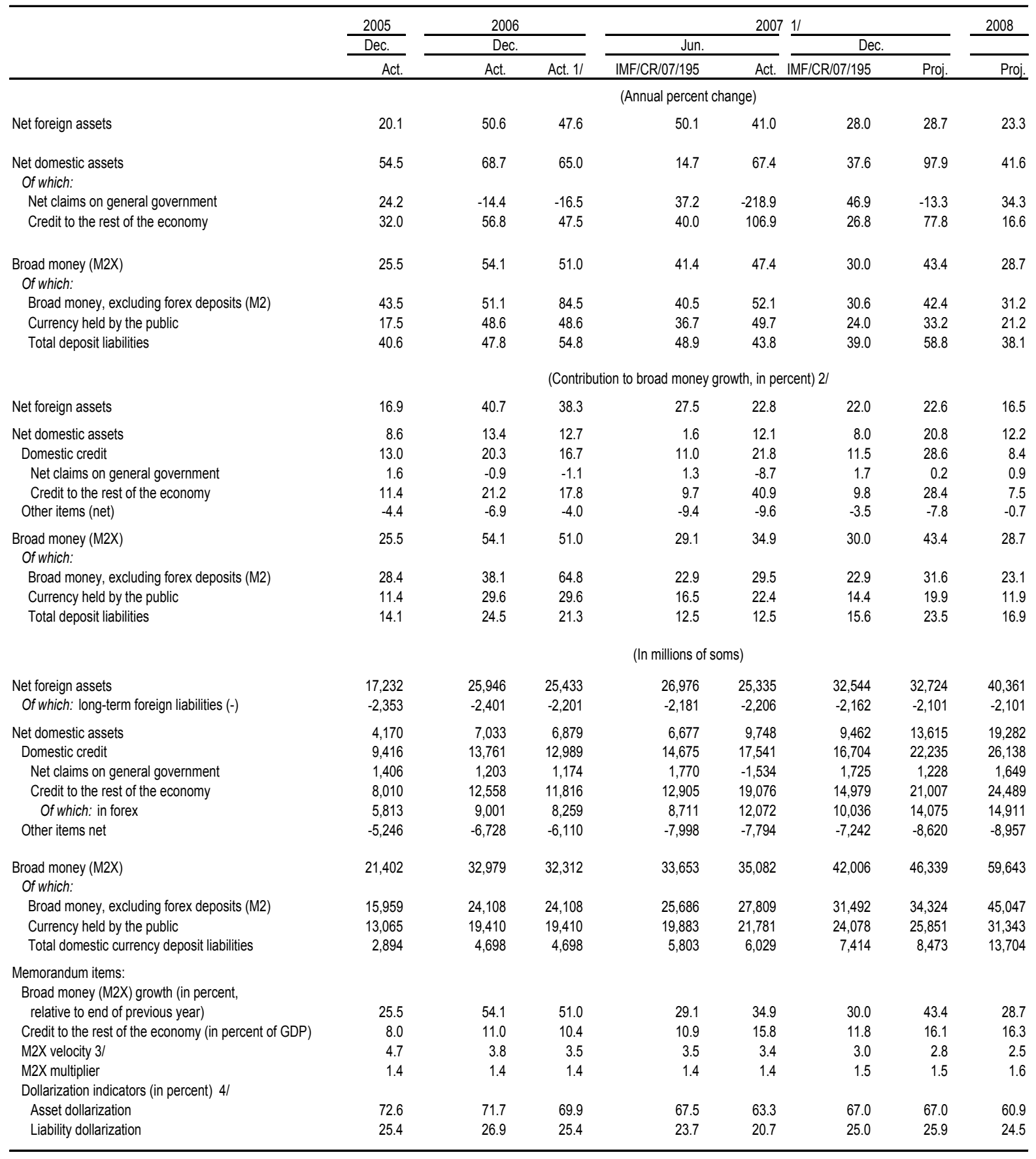

Sources: Kyrgyz authorities; and Fund staff estimates and projections.

1/ Based on new program exchange rates (including $38.5 \mathrm{soms} /$ dollar) specified in the TMU. The monetary survey has been augmented since March 2007 to include the balances of Ayil Bank (formerly KAFC, a NBFI), which introduces a break into the series.

$2 /$ Contribution is defined as annual change of asset stock relative to previous year's broad money stock (in percent).

3/ 12-month GDP over end-period broad money.

4/ Asset dollarization is measured as the ratio of credit extended in foreign exchange to total banking system credit to the private sector, and liability dollarization as the share of foreign exchange deposits in broad money. 
Table 11. Kyrgyz Republic: Balance of Payments, 2005-10 (In millions of U.S. dollars)

\begin{tabular}{|c|c|c|c|c|c|c|c|}
\hline & 2005 & 2006 & 2007 & & 2008 & 2009 & 2010 \\
\hline & Act. & Act. & IMF/CR/07/195 & Proj. & \multicolumn{3}{|c|}{ Proj. } \\
\hline $\begin{array}{l}\text { Current account balance } \\
\text { excluding transfers }\end{array}$ & $\begin{array}{r}78 \\
-422\end{array}$ & $\begin{array}{l}-186 \\
-902\end{array}$ & $\begin{array}{r}-416 \\
-1,172\end{array}$ & $\begin{array}{r}-624 \\
-1,537\end{array}$ & $\begin{array}{r}-616 \\
-1,574\end{array}$ & $\begin{array}{r}-524 \\
-1,523\end{array}$ & $\begin{array}{r}-457 \\
-1,520\end{array}$ \\
\hline Trade balance & -311 & -782 & $-1,038$ & $-1,412$ & $-1,380$ & $-1,295$ & $-1,279$ \\
\hline Exports, fob & 794 & 1,011 & 1,011 & 1,379 & 1,705 & 1,880 & 2,005 \\
\hline CIS countries & 412 & 581 & 426 & 820 & 909 & 958 & 1,011 \\
\hline Of which: re-exports of consumer goods $1 /$ & 107 & 200 & $\ldots$ & 314 & 344 & 361 & 379 \\
\hline Non-CIS countries & 382 & 430 & 585 & 559 & 796 & 923 & 994 \\
\hline Of which: gold & 231 & 206 & 340 & 211 & 422 & 541 & 602 \\
\hline Of which: re-exports of oil products & 31 & 71 & $\ldots$ & 126 & 140 & 138 & 137 \\
\hline Imports, fob & 1,106 & 1,792 & 2,049 & 2,792 & 3,085 & 3,175 & 3,284 \\
\hline CIS countries & 641 & 926 & 1,034 & 1,432 & 1,595 & 1,612 & 1,642 \\
\hline Of which: energy & 460 & 460 & 492 & 718 & 837 & 854 & 881 \\
\hline Non-CIS countries & 866 & 866 & 1,015 & 1,360 & 1,490 & 1,564 & 1,642 \\
\hline Of which: goods for re-exports $1 /$ & 97 & 182 & 186 & 285 & 313 & 328 & 458 \\
\hline Services & -36 & -86 & -78 & -63 & -105 & -114 & -119 \\
\hline Receipts & 256 & 374 & 408 & 524 & 581 & 605 & 636 \\
\hline Payments & -291 & -461 & -486 & -587 & -686 & -719 & -754 \\
\hline Income & -75 & -34 & -57 & -62 & -88 & -114 & -122 \\
\hline Interest payments $2 /$ & -36 & -18 & -25 & -26 & -35 & -45 & -47 \\
\hline Other net income & -39 & -16 & -32 & -36 & -54 & -69 & -75 \\
\hline Current Transfers (net) & 500 & 716 & 757 & 913 & 958 & 999 & 1,063 \\
\hline Of which: private & 477 & 704 & 715 & 880 & 924 & 970 & 1,028 \\
\hline Capital Account & 6 & -36 & -34 & -27 & -20 & -3 & -2 \\
\hline Official & 50 & 37 & 43 & 46 & 57 & 66 & 59 \\
\hline Private & -44 & -73 & -77 & -73 & -76 & -69 & -62 \\
\hline Financial account (including errors and omissions) & -35 & 403 & 576 & 884 & 823 & 690 & 626 \\
\hline Commercial banks & -27 & -44 & 25 & 19 & -16 & -8 & 5 \\
\hline Medium-and long-term loans, net & 12 & 77 & 66 & 86 & 78 & 70 & 13 \\
\hline Disbursement & 90 & 115 & 107 & 122 & 132 & 149 & 162 \\
\hline Amortization 2/ & -59 & -37 & -42 & -36 & -54 & -79 & -150 \\
\hline FDI and portfolio investment (net) & 45 & 236 & 109 & 247 & 259 & 278 & 298 \\
\hline Derivatives and net short-term flows (incl. errors \& omissions) & -65 & 190 & 375 & 552 & 526 & 381 & 349 \\
\hline Overall balance & 49 & 181 & 127 & 233 & 188 & 163 & 167 \\
\hline Financing & -49 & -181 & -127 & -233 & -188 & -163 & -167 \\
\hline Net international reserves & -93 & -193 & -140 & -238 & -201 & -163 & -167 \\
\hline Gross official reserves (- increase) & -81 & -170 & -120 & -216 & -180 & -140 & -141 \\
\hline IMF (net) & -12 & -24 & -20 & -22 & -21 & -23 & -27 \\
\hline Exceptional financing (including arrears) & 44 & 4 & -2 & 0 & -5 & 0 & 0 \\
\hline \multicolumn{8}{|l|}{ Memorandum items: } \\
\hline GDP (in millions of U.S. dollars) & 2,460 & 2,822 & 3,287 & 3,488 & 4,066 & 4,676 & 5,081 \\
\hline Current account balance (in percent of GDP) & 3.2 & -6.6 & -12.6 & -17.9 & -15.1 & -11.2 & -9.0 \\
\hline Growth of exports of goods and services (volume, percent) & -5 & 11.9 & 16.7 & 20.8 & 17.3 & 10.1 & 6.6 \\
\hline Growth of imports of goods and services (volume, percent) & 11.2 & 42.6 & 11.4 & 38.9 & 9.3 & 6.2 & 5.8 \\
\hline External public debt (US\$ million) $3 /$ & 1,918 & 1,982 & 2,005 & 2,014 & 2,052 & 2,072 & 2,096 \\
\hline as percent of GDP & 78.0 & 70.2 & 61.0 & 57.7 & 50.5 & 44.3 & 41.2 \\
\hline External public debt (NPV US\$ million) 3/ & 1,145 & 1,257 & 1,222 & 1,275 & 1,309 & 1,332 & 1,358 \\
\hline as percent of GDP & 46.5 & 44.5 & 37.2 & 36.6 & 32.2 & 28.5 & 26.7 \\
\hline as percent of exports & 109.1 & 90.7 & 86.1 & 67.0 & 57.3 & 53.6 & 51.4 \\
\hline Public debt service-to-exports ratio $3 / 4$ / & 6.5 & 4.7 & $\ldots$ & 3.5 & 3.5 & 3.5 & 3.4 \\
\hline Gross reserves $5 /$ & 609 & 817 & 937 & 1,053 & 1,233 & 1,373 & 1,514 \\
\hline in months of subsequent year's imports & 3.2 & 2.9 & 4.0 & 3.4 & 3.8 & 4.1 & 4.3 \\
\hline
\end{tabular}

Sources: Kyrgyz authorities; and Fund staff estimates and projections.

$1 /$ Reflects adjustments to the official statistics to account for the staff's estimate for re-exports through informal border trade.

2/ Starting 2006, interest and amortization reflect bilateral agreements signed following the March 2005 Paris Club agreement to grant debt relief on London terms.

3/ Public and publicly guaranteed debt.

4/ Net of rescheduling.

5/ Valued at end-period exchange rates. 


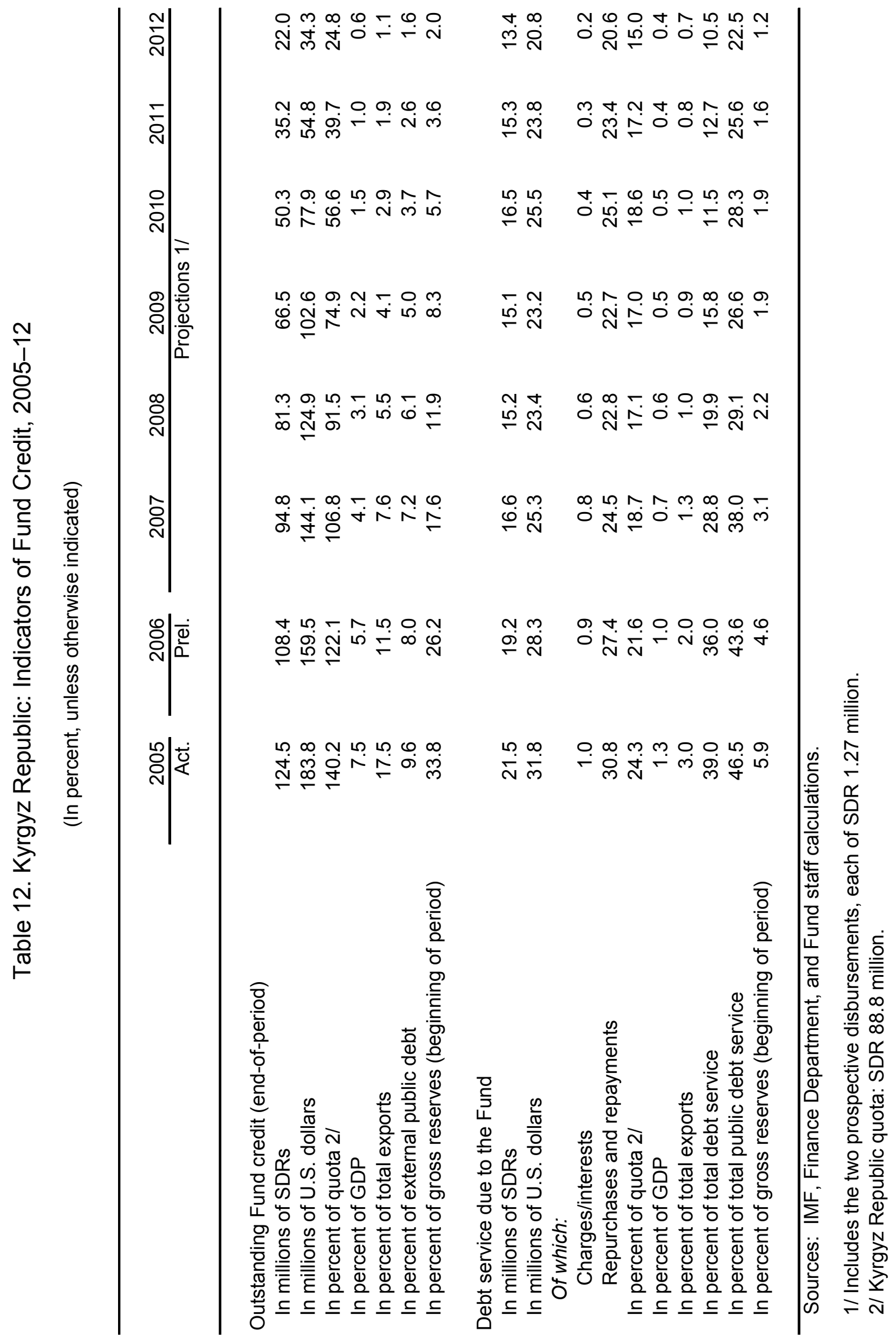




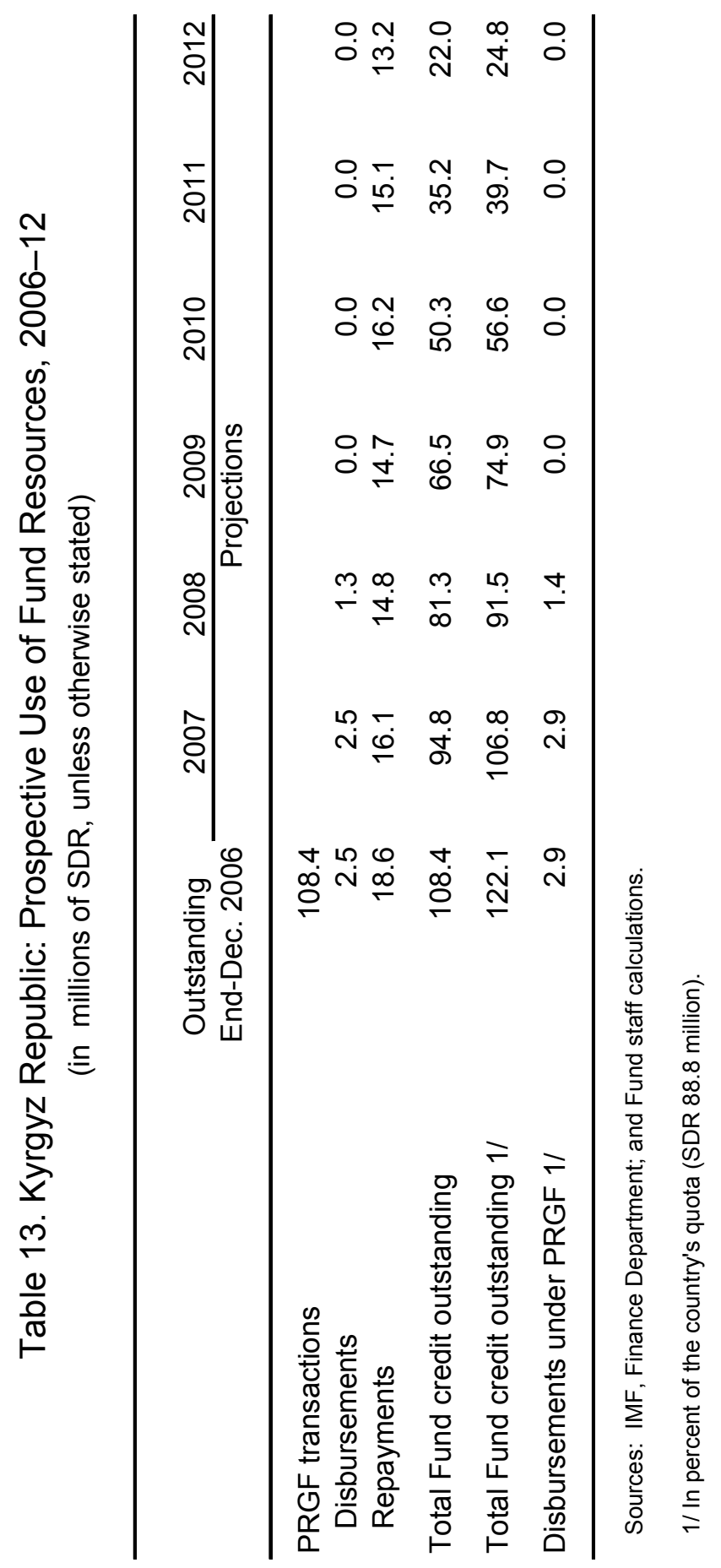




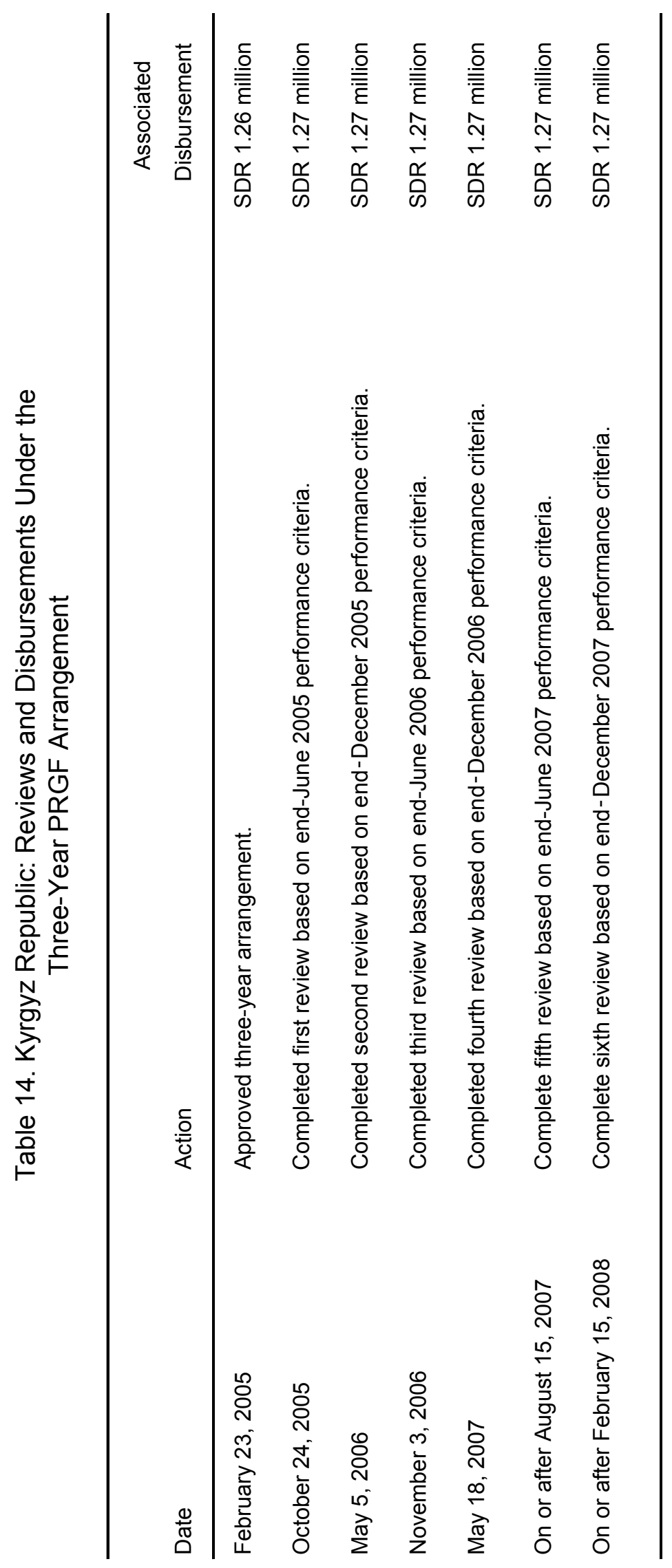




\section{AtTAChMENT I}

November 1, 2007

Mr. Dominique Strauss-Kahn

Managing Director

International Monetary Fund

$70019^{\text {th }}$ Street, N.W.

Washington, D.C. 20431

Dear Mr. Dominique Strauss:

Further to our letter of April 24, 2007, reviewing our performance under the program supported by the Poverty Reduction and Growth Facility (PRGF) arrangement approved in February 2005, we are pleased to inform you that all quantitative performance criteria and structural benchmarks for end-June 2007 were met, some with comfortable margins (Table 1). As indicated in Table 2, implementation of some of the end-December 2006 and end-March 2007 structural benchmarks under the program (especially those requiring parliamentary approval) has been delayed. We are now seeking to expedite the passage of key pending economic legislation and to add momentum to financial sector and public financial management reforms. The attached Memorandum of Economic Policies (MEP) describes program implementation to date, sets out the government's economic strategy for the remainder of the program period, and includes program understandings reached with the Fund.

The Executive Board concluded the fourth review under the PRGF arrangement on May 18, 2007. We request disbursement of the SDR 1.27 million tranche upon Board completion of the fifth review, as well as an extension of the arrangement until May 31, 2008 to permit completion of the $6^{\text {th }}$ and final review under the arrangement.

We believe that the policies specified in the MEP provide a strong basis for sustaining growth in a low-inflation environment and alleviating poverty. We stand ready, nevertheless, to take any necessary additional measures to achieve the program's objectives. The government will continue to provide the Fund with the necessary information for assessing progress in implementing our program, as specified in the Technical Memorandum of Understanding (TMU), and will consult with Fund staff and management on any measures that may be appropriate at the initiative of the government or whenever the Fund requests a consultation.

The government intends to make public this letter and the staff report for the fifth review under the PRGF arrangement. Accordingly, it authorizes the IMF to arrange to post these documents on the Fund's website once the Board completes its review.

Sincerely yours,

/s/

Almazbek Atambaev

Acting Prime Minister

Kyrgyz Republic
Abdybaly tegin Suerkul

Acting Chairman

National Bank of the Kyrgyz Republic 


\section{Attachment II. Memorandum of Economic Policies for the Kyrgyz Republic}

\section{RECENT ECONOMIC PERFORMANCE}

1. The government's economic program for 2005-08, supported by the PRGF arrangement approved by the Fund's Executive Board in February 2005, aims to achieve sustained and rapid economic and social development in a low-inflation environment. This Memorandum reviews program implementation to date and describes our policies for the remainder of the program period.

2. The government has maintained macroeconomic discipline and adhered to the PRGF-supported program thus far in 2007. All end-June quantitative performance criteria (PCs) were observed, in some cases with ample margins, although the indicative limits on reserve money and the quasi-fiscal deficit (QFD) of the energy sector were missed - the latter mainly because of a postponement of the tariff increases envisaged in the program, more than offsetting ongoing efforts to improve payments discipline and curb technical and commercial losses. Moreover, all end-June and end-September 2007 structural benchmarks (SBs) were met (Table 2), and — as discussed below-we are seeking to fulfill several missed SBs for earlier test dates. In line with our commitment to improve the business climate, we have created a high-level investment council and introduced measures to streamline the regulatory apparatus, simplify business inspections and create an enabling environment for SMEs.

3. Economic activity has continued to rebound in 2007, with year-on-year real GDP growth of 8.5 percent during the period January-September, and non-gold output growth of 9.2 percent. Total and nongold GDP growth in the period October 2006-September 2007 (against the preceding 12 months) were 6.9 percent and 7.8 percent, respectively. Twelvemonth inflation rose to 13 percent in September, owing to an easing of liquidity conditions and an externally driven spike in foodstuff prices. The half-year external current account deficit amounted to about \$290 million (22 percent of GDP at an annualized rate), with buoyant remittances and sustained export growth moderating the effect of a rapid increase in imports. As the current account deficit was over-financed by rising FDI and other private capital inflows and the NBKR engaged in sizable (mostly unsterilized) intervention in the foreign exchange market, gross reserves increased to $\$ 1$ billion (3.3 months of projected 2008 imports of goods and services) by end-August.

4. Year-to-date fiscal performance has been better than envisaged because of buoyant receipts from taxes on imports and under-execution of budgeted spending. As a result, the general government posted an overall surplus of 1.9 percent of GDP at an annualized rate during the first half of the year, compared with a programmed deficit. Parliament passed a supplementary 2007 budget, mainly authorizing one-off outlays for the August 2007 summit of the Shanghai Cooperation Organization premised on an upward revision in revenue, thereby limiting the fiscal deficit to around 3.1 percent of GDP as envisaged in the program.

5. Monetary policy has been conducted lately in an environment of stronger-thanexpected foreign exchange inflows and continued remonetization. As a consequence, the NBKR has engaged in significant (mostly unsterilized) intervention in the foreign exchange 
market to mitigate the appreciation of the som against the U.S. dollar, sparking a surge in reserve money growth. Moreover, the rebound in economic activity and the entry of new commercial banks have been accompanied by rapid expansion in private sector credit (albeit from a low base) and broad money, partly covered by an increase in short-term foreign liabilities. However, the som has remained broadly stable in real effective terms since end2006.

6. The NBKR continues to enhance supervision and has established a framework to assess market, operational, country and foreign exchange risks. It has also launched the envisaged independent review of its internal audit function (with assistance from the Swiss National Bank); taken steps to improve the payment system; introduced an enabling legal and supervisory framework for Islamic banking; developed an action plan to align the supervisory framework with the new AML/CFT legislation; and started preparations to introduce mandatory deposit insurance in 2008. A tender for divestiture of two-thirds of the public sector's equity in the Agricultural (Ayil) Bank (formerly KAFC) is now poised for submission to parliament. While legislation to enhance the NBKR's legal independence (an end-December $2006 \mathrm{SB}$ ) has yet to obtain parliamentary support, the government plans to increase the NBKR's de facto autonomy and it has taken steps to enhance coordination between the monetary and fiscal authorities.

\section{Program ObJectives ANd Economic Policies for 2007}

7. In line with the Kyrgyz Republic's Country Development Strategy (CDS), our economic policy is geared towards poverty alleviation and private sector-led growth in a lowinflation environment. To achieve these objectives, the government will continue to maintain macroeconomic stability, deepen financial sector and public financial management (PFM) reforms, and remove structural impediments to growth, while limiting its direct intervention in the economy.

8. The vigorous economic recovery in the year to date suggests that output growth could reach 7.5 percent during 2007, compared with the original target of 6.5 percent. However, the recent upturn in inflation could make it difficult to achieve the original 5-6 percent target. To dampen inflationary pressures, we are tightening monetary policy and undershooting the program's original fiscal limit. The rebalancing of the macroeconomic policy mix should keep inflation below 9 percent by year's-end and limit the external current account deficit to 18 percent of GDP. Our economic program for 2008 targets output growth at 7 percent and end-year inflation at 7-8 percent, on the strength of fiscal consolidation and economic reforms anchored on the CDS. On this basis, and aided by a recovery in gold exports, the external current account deficit would narrow to 15 percent of GDP and end-year gross reserves would amount to 3.8 months of projected 2009 imports of goods and services.

\section{A. Fiscal Issues}

9. Fiscal consolidation will continue to underpin macroeconomic stability. Accordingly, we expect the overall general government deficit to amount to 2.2 percent of GDP in 2007, mostly on the strength of continued revenue gains. To dampen the upturn in consumer prices stemming from higher international commodity prices, we have announced extraordinary public sector imports of grains and fuel amounting to 0.5 percent of GDP. To alleviate the 
social costs of higher food prices, we have also announced a 10 percent increase in pensions and selected categories of welfare benefits from October 1, 2007, accompanied by efforts to better target welfare recipients - all of which will be covered by a reassignment of budgetary appropriations already approved by parliament.

10. The 2008 budget sent to parliament in September keeps the general government deficit around 2.2 percent of GDP. This is consistent with an increase in pensions in the order of 10 percent during 2008 and an increase in the public wage bill in the order of 25-30 percent during the year to stem the exodus of qualified personnel and to scale-up social sector spending. To make room for further improvements in remuneration over the medium term while stabilizing the wage bill relative to GDP, we will seek assistance from the World Bank to design a comprehensive civil service reform that would include reductions in personnel; harmonization of pay grades for comparable jobs across the public sector; and introduction of incentives and sanctions geared at enhancing performance management. Continued revenue gains anchored on sustained output growth and further improvements in revenue administration should allow us to eventually reduce the rate of social fund contributions further to 25 percent. We will also seek timely passage of the new tax code, after forging a consensus on the different drafts before parliament.

11. The phased three-year reduction in the retirement age through 2009 enacted by parliament entails significant near-term costs. While we continue to seek political support for reversing this fiscally unsustainable initiative, we will cover its immediate costs by (a) broadening the social fund revenue base and stepping up its collection efforts; and (b) providing central government transfers as needed, including to permit the further step-wise reductions in the rate of social fund contributions mentioned earlier. To put the social fund finances on a sound longer-term footing, we will forge a domestic consensus for designing a comprehensive pension reform with World Bank assistance. Key elements under consideration include a streamlining of social benefits and a broadening in the coverage of social safety nets, as well as introduction of fully funded private pension funds within a few years - premised on creating an appropriate legal and regulatory framework for these funds and developing suitable asset classes for them to invest their resources.

12. We have embarked on donor-assisted PFM reforms, especially to strengthen budgetary design and implementation and direct pro-poor spending to priority sectors identified in the CDS. We will also seek timely passage of the Internal Audit Law submitted to Parliament in September. Moreover, we are implementing the new Public Procurement Law, which entails multi-year procurement planning and prohibits the State Agency on Public Procurement and Material Reserves from participating directly in the procurement process. In keeping with the phased move to a three-tier government and budgetary structure (comprising central, regional and local governments), we will continue to help local authorities in their efforts to build capacity and will clearly demarcate revenue and expenditure competencies at each tier.

13. The new Medium-Term Budgetary Framework (MTBF) includes a new classification of poverty reducing spending and the tracking of pro-poor spending in the monthly budget reports. It also outlines a strategy for developing health, education, social protection, agriculture, and transport and communication, along with criteria for identifying sectoral priorities and deepening fiscal decentralization. We will update the MTBF in the coming months to reflect the tightening of the fiscal stance mentioned above and the envisaged fiscal 
consolidation through 2010. The updated MTBF will include sectoral ceilings directly and transparently linked to annual budgets, starting with the 2008 budget. Further, the annual budget process is being strengthened with the inclusion of functional, economic and administrative summaries in the budget bill.

\section{B. Monetary and Financial Sector Policies}

14. To dampen inflationary pressures, the NBKR has begun to tighten liquidity conditions, seeking to slow reserve money growth to about 34 percent by end-2007 (from nearly 40 percent in the 12 months to September 2007) and about 21 percent by end-2008. In this vein, it has also outlined indicative limits for end-2008 on its net domestic assets and reserve money and an indicative floor on its net international reserves (see Table 1). To achieve these goals, the NBKR will operate its managed exchange rate float more flexibly, limiting its intervention in the foreign exchange market to smoothing short-term fluctuations and sterilizing any residual intervention. This will, in turn, be accompanied by improvements in its indirect monetary control instruments and more flexible pricing of these instruments. We will take measures by end-December 2007 to simplify the structure of long-term government securities held by the NBKR, without adverse effects on the value of the NBKR's balance sheet. This should give greater scope to the NBKR for conducting open market operations.

15. We have introduced several measures in recent years to strengthen the financial system, especially regarding supervision, the payment system, and curtailment of money laundering and the financing of terrorism. Going forward, we will deepen these reforms and focus on introducing mandatory deposit insurance for small depositors in early 2008 and on stepping up supervision (including through strict enforcement of procedures for tracking market, operational and country risks) in light of the rapid expansion in private sector credit. The State Service for Financial Reporting and Monitoring will further strengthen supervision in the main areas under its purview (insurance companies and financial institutions operating in the stock exchange), and will enhance information sharing with the NBKR.

16. To upgrade the payment system, the enhanced real-time gross settlement system will become fully operational early next year, and we will submit legislation adding flexibility in the use of bank accounts for settlement purposes. Moreover, to ensure finality of bank resolution, we will seek approval of amendments to the bank bankruptcy law modifying provisions introduced last September that allowed reinstatement of banks that are insolvent and in the process of liquidation. Furthermore, to foster mortgage and other term lending, we have secured passage of amendments to the civil code which - together with amendments to the land code before parliament, as well as amendments to the laws governing collateral and a new housing code to be proposed - are expected to strengthen the legal foundation for the use and for the seizure of collateral in cases of default. Further, we will continue to enhance consolidated bank supervision regulations to adequately monitor risks.

\section{External Debt Issues}

17. The updated low-income country debt sustainability analysis (LIC DSA) prepared jointly by Fund and World Bank staff shows that the Kyrgyz Republic's debt burden remains 
relatively heavy and that the country remains vulnerable to external shocks and natural disasters, despite the improvement in key debt indicators stemming mainly from significant gains in domestic revenue mobilization, rapid output growth and a strengthening of the currency. To put the debt sustainability ratios on a steady downward path, we are consolidating the fiscal position (as noted above) and improving public debt management with Swiss technical assistance; in this connection, we plan to adopt a best-practice external debt management strategy (a missed program benchmark) by end-2007. In addition, the program will continue to prohibit public or publicly guaranteed external borrowing on nonconcessional terms and adhere to a minimum 45 percent grant element on any concessional loans.

\section{Other Structural Reforms}

18. To help deliver reliable energy supplies for the domestic and external markets and curtail the sector's quasi-fiscal deficit (QFD) over time, we have updated the energy sector action plan discussed earlier with the World Bank. In this connection, we have launched a feasibility study for construction of the Kambarata I and II power generation complex and plan to gradually privatize the power distribution system. In addition, we are intensifying our actions to stamp out corruption in the sector, boost utility bill collections and reduce technical losses and theft, which are already showing encouraging results. Furthermore, in the coming months we will announce phased semi-annual adjustments in electricity tariffs beginning in April 2008, cushioned by social safety nets provided in the budget, with a view to reaching cost-recovery tariffs by 2010. On this basis, we expect to meet the end-2007 indicative limit on the electricity sector's QFD (5.1 percent of GDP), and to reduce it further to 4.8 percent in 2008 .

19. To bolster the prospects for rapid, sustained private sector-led growth, we will continue to fight corruption, improve the business climate and strengthen property rights. These actions will be supported by financial and technical assistance from the U.S. Millennium Challenge Corporation, the World Bank and other donors. We plan to introduce a number of measures through end-2008 to foster SME development and private sector-led growth more generally, including sunset ("guillotine") clauses for the elimination of redundant regulations and steps to further reduce government intervention in the economy and to attract foreign direct investment.

\section{E. Program Monitoring}

20. The program will continue to be monitored through semi-annual reviews. In keeping with our determination to dampen inflationary pressures, we will make every effort to undershoot the program's original fiscal limits and to significantly slow the growth of reserve money in Q4 2007, as mentioned earlier. Moreover, we will strive to comply with the missed structural benchmarks for end-December 2006 and end-March 2007 (see Table 2), and we have outlined the broad parameters of our 2008 macroeconomic program (including indicative targets), which will be updated at the time of the sixth and final review under the arrangement in early 2008. Completion of that review will hinge on observance of the endDecember 2007 quantitative PCs outlined in Table 1 and satisfactory progress in implementation of the program's structural benchmarks. Detailed definitions and reporting 
requirements for all quantitative PCs and data sources are presented in the Technical Memorandum of Understanding attached with the Country Report No. 07/195. 


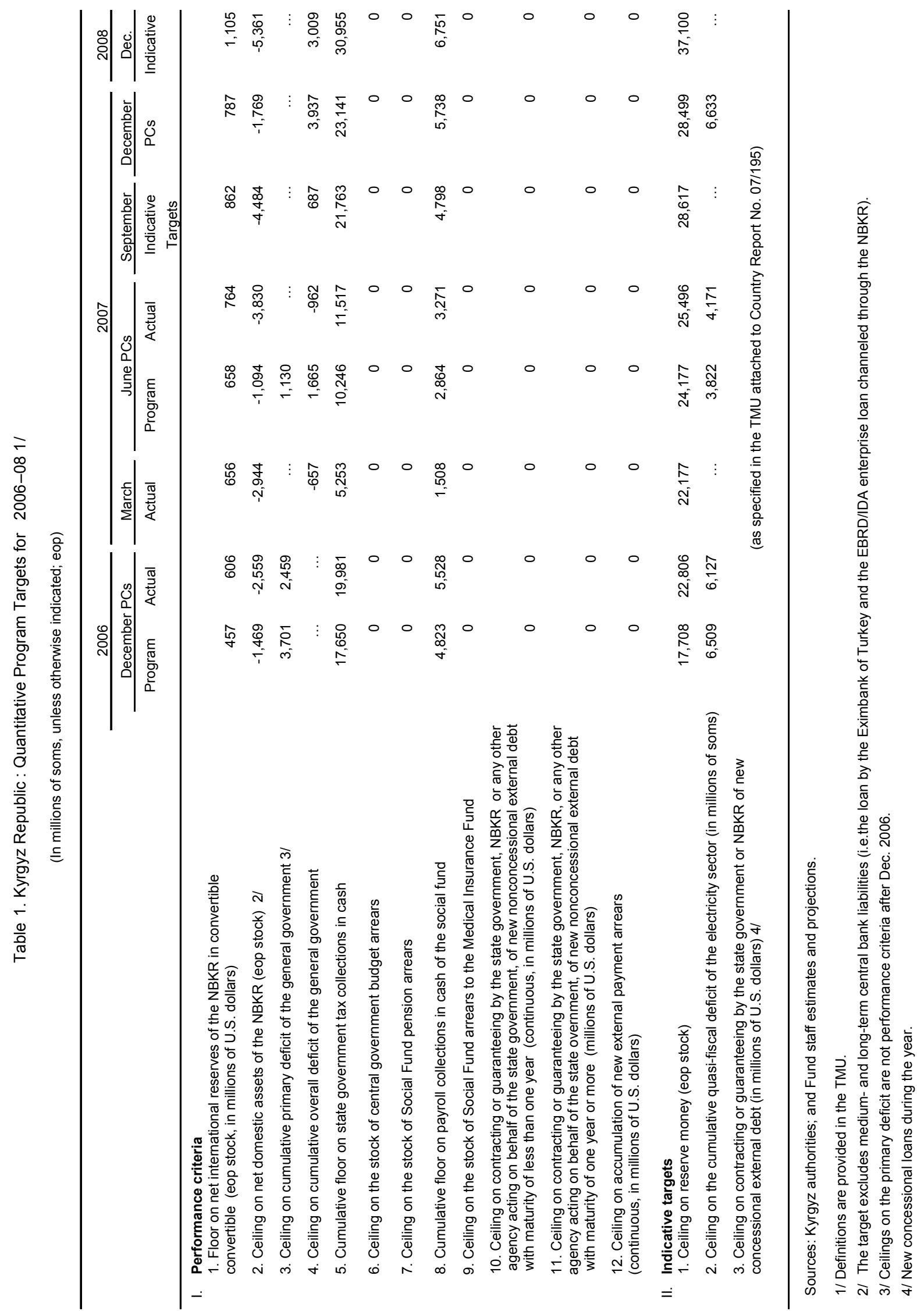




\section{Table 2. Kyrgyz Republic: Structural Conditionality, 2006-07}

\section{September-December 2006}

\section{Structural benchmarks for end-September 2006}

- Prepare an action plan to reduce the energy sector's quasi-fiscal deficit in close cooperation with World Bank staff, addressing problems of transmission and distribution losses, payment indiscipline, and tariff adjustment. [Observed]

- Expand the operation of the Large Taxpayers Unit to cover at least 60 percent of tax revenues. [Observed]

\section{Structural benchmarks for end-December 2006}

- Conduct an independent review of the NBKR's internal audit function. The review could be performed by the internal audit department of another central bank, and should include a review of the capacity of the NBKR's internal audit division, as recommended by the Safeguards Assessment Report conducted by Finance Department in 2005. [Not observed]

- Bring KAFC to the point of sale and issue a privatization tender for the company. [Not observed]

- Submit to IMF staff a report prepared by the ministry of labor and social protection recommending measures to improve labor market flexibility. [Observed]

- Secure approval of legislation that has been already sent to parliament to enhance the NBKR's legal independence and ensure legal protection of its employees in performing official duties. [Not observed]

\section{March-December 2007}

\section{Structural benchmarks for end-March 2007}

- The government will submit to parliament amendments (drafted by the NBKR) to the civil, housing and land codes, as well as to all the laws governing collateral, in order to harmonize provisions on collateralized lending by financial institutions and facilitate collateral seizure in cases of default. [Not observed]

- Approval of the tax code bill that is before parliament. [Not observed]

- The government will adopt a new medium-term external debt management strategy aimed at ensuring external debt sustainability, as described in paragraph 24 of the MEP for the third review under the arrangement. [Not observed]

\section{Structural benchmarks for end-June 2007}

- The NBKR will implement regulations for consolidated supervision to monitor risks faced by financial institutions, in line with the recommendations of the 2005 Basel Core Principles for Effective Banking Supervision Assessment. [Observed]

- The government will introduce a new and detailed budget classification, based on the best practice reporting of government finances (GFS 2001), which will permit monitoring of poverty reducing expenditures in the monthly budget execution reports. [Observed] 


\section{Table 2 (Concluded). Kyrgyz Republic: Structural Conditionality, 2006-07}

\section{Structural benchmarks for end-September 2007}

- Submit to IMF staff a written Memorandum of Understanding agreed between the NBKR and the State Agency for Financial Supervision and Reporting (SAFSR), delineating the specific supervisory responsibilities of the SAFSR and establishing modalities for information-sharing between them, as recommended by the FSAP update mission. [Observed]

- Submit to parliament an internal audit law for government agencies in line with best international audit practices, in order to establish an appropriate framework for internal public sector controls. [Observed]

\section{Structural benchmarks for end-December 2007}

- To ensure finality of bank resolution, the government and the NBKR will secure parliamentary approval of further amendments to the bank bankruptcy law modifying the provisions introduced in September 2006, which allowed reinstatement of banks that are insolvent and in the process of liquidation.

- Submit to IMF staff a best-practice, time-bound action plan to modernize customs administration, including greater selectivity of customs control based on risk criteria and expanding post-clearance audits.

- Submit to parliament enabling legislation to enhance flexibility in the use of bank accounts (including demand deposits) for settlement purposes by legal entities and physical persons. 



\section{INTERNATIONAL MONETARY FUND}

KYRGYZ REPUBLIC

\section{Fifth Review Under the Three-Year Arrangement Under the Poverty Reduction and Growth Facility-Informational Annex}

November 2, 2007

Contents

Page

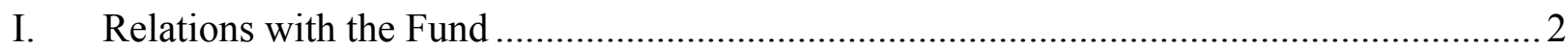

II. Relations with the World Bank Group …………….................................................

III. Relations with the Asian Development Bank ………................................................... 7

IV. Relations with the European Bank for Reconstruction and Development ........................... 9

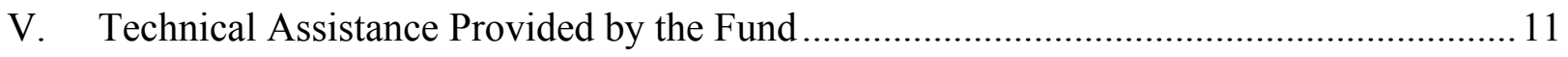

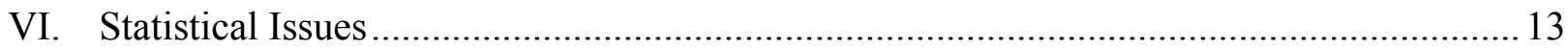


ANNEX I. KYRGYZ REPUBLIC-RELATIONS WITH THE FUND

(As of September 30, 2007)

I. Membership Status: Joined: 05/08/1992; Article VIII

II. General Resources Account

Quota

Fund Holdings of Currency

Reserve Position

III. SDR Department

Holdings

IV. Outstanding Purchases and Loans

PRGF Arrangements
SDR Million

88.80

88.80

0.00

SDR Million

10.38

SDR Million

96.33
Percent of

Quota

100.00

100.00

0.01

Percent of Allocation N/A

Percent of Quota 108.48

V. Latest Financial Arrangements

\begin{tabular}{|c|c|c|c|c|}
\hline Type & Approval & $\begin{array}{c}\text { Expiration } \\
\text { Date }\end{array}$ & $\begin{array}{c}\text { Amount } \\
\text { Approved } \\
\text { (SDR Million) }\end{array}$ & $\begin{array}{c}\text { Amount } \\
\text { Drawn } \\
\text { (SDR Million) }\end{array}$ \\
\hline PRGF & $03 / 15 / 2005$ & $03 / 14 / 2008$ & 8.88 & 6.34 \\
\hline PRGF & $12 / 06 / 2001$ & $03 / 14 / 2005$ & 73.40 & 73.40 \\
\hline PRGF & $06 / 26 / 1998$ & $07 / 25 / 2001$ & 73.38 & 44.69 \\
\hline
\end{tabular}

VI. Projected Payments to Fund

(SDR million; based on existing use of resources and present holdings of SDRs)

\begin{tabular}{lrrrrr}
\hline & \multicolumn{5}{c}{ Forthcoming } \\
\cline { 2 - 6 } & 2007 & 2008 & 2009 & 2010 & 2011 \\
\hline Principal & 2.78 & 14.80 & 14.73 & 16.24 & 15.31 \\
Charges/Interest & 0.25 & 0.43 & 0.35 & 0.27 & 0.19 \\
Total & 3.03 & 15.23 & 15.08 & 16.51 & 15.50 \\
\hline
\end{tabular}

\section{Status of HIPC and MDRI Assistance}

The Executive Board considered the preliminary HIPC document on October 13, 2006.

However, earlier this year, the authorities have decided not to avail themselves of HIPC and MDRI assistance. The updated LIC DSA shows that the Kyrgyz Republic does not qualify for HIPC debt relief. 


\section{Safeguards Assessments}

Under the Fund's safeguards assessment policy, the National Bank of the Kyrgyz Republic (NBKR) is subject to an assessment with respect to the PRGF arrangement, which was approved on March 15, 2005. An updated safeguards assessment of the NBKR was completed on October 14, 2005. The assessment found that the NBKR's safeguards framework has been strengthened since the previous assessment completed in 2002. However, a number of areas were identified where further steps would solidify the progress achieved, which include improving oversight of the audit processes and the internal control systems by establishing an audit committee, strengthening the legal framework for NBKR's autonomy, and enhancing the NBKR's internal audit function.

\section{Exchange Rate Arrangements}

The currency of the Kyrgyz Republic has been the som (100 tyiyn =1 som) since May 15, 1993. The Kyrgyz Republic's exchange regime is classified as a managed float with no preannounced path for the exchange rate. The NBKR publishes daily the exchange rate of the som in terms of the U.S. dollar, which is determined in the interbank foreign exchange market. The Kyrgyz Republic maintains an exchange system that is free of restrictions on the making of payments and transfers for current international transactions, except for exchange restrictions maintained for security reasons relating to the restriction of financial transactions and the freeze of accounts of certain individuals or organizations associated with terrorism pursuant to (i) relevant UN Security Council resolutions and (ii) the list of current terrorist organizations designated by the U.S. Secretary of State. The authorities have notified these measures to the Fund pursuant to Executive Board decision No. 144-(52/51) in May 2007 (see EBD/07/96, 8/7/07 and EBD/04/129, 11/19/04).

\section{Article IV Consultations}

The Kyrgyz Republic is on the 24-month consultation cycle. The last Article IV consultation discussions were held in August 2006 and were completed by the Executive Board in November 2006.

\section{FSAP Participation and ROSC Assessment}

An FSAP update mission in October 2006 reviewed progress since the 2002 assessment, and the Board considered the Financial System Stability Assessment (FSSA) along with the $4^{\text {th }}$ PRGF review in May 2007. A fiscal ROSC mission was held in March 2001 and the ROSC Fiscal Transparency Module was published on March 13, 2002. A data ROSC mission was held in November 2002 and the ROSC Data Module was published in November 2003. A fiscal ROSC reassessment was held in September 2007. 


\section{Resident Representative}

The seventh resident representative of the Fund in the Kyrgyz Republic, Mr. McHugh, took up his post in Bishkek in late September 2006. 


\section{ANNEX II. KYRGYZ REPUBLIC-RELATIONS WITH THE WORLD BANK GROUP} (As of October 19, 2007)

1. The new Joint Country Support Strategy (JCSS) covering FY07-10 was approved by the Board on June 19, 2007. The WB Country team jointly with four development partners (ADB, DFID, SWISS, and UN Agencies) developed JCSS to support implementation of the Country Development Strategy. The JCSS is closely aligned with the Government's development goals. The strategic choices agreed among the development partners are: (i) focus on areas where support for reforms is already embedded; (ii) mitigate risks associated with high indebtedness and growth volatility; (iii) focus on basic reforms, as opposed to complex operations; and (iv) focus on economic and sector work and capacity building.

2. The World Bank Group Program within JCSS. The WBG program contributes to the strategic goals outlined in the JCSS, with a particular focus on supporting the Government's efforts to improve the environment for business and economic growth and improve the quality of and access to basic services (health, education, water and sanitation). The WBG strategy emphasizes greater selectivity given the limited IDA resources and limitations placed on the Government's own public investment program. Building on lessons learned, and in line with the principles of the JCSS, the Bank Program will build on successful results achieved in first generation projects, target activities where the Bank can show visible results to the population, and leverage our lending and analytical work to attract financing from other development partners. The proposed annual allocation for the Kyrgyz Republic under JCSS 2007-2010 is about \$30 million U.S. dollars.

3. International Development Association (IDA): As of October 2007 the active World Bank portfolio comprise of 19 operations with total commitments of US\$255.2, of which US\$141.5 million (49.2 percent) remains to be disbursed. IDA grants in the current portfolio account for about 38.7 percent of total commitment. Four new projects-Reducing Technical Barriers for Entrepreneurship and Trade, Water Management Improvement, Village Investment Project-II, and Avian Influenza Control were approved by the Board and became effective in FY07. Another project, the second On-farm Irrigation, was approved by the Board on June 19, 2007 and is expected to become effective shortly. In addition to the country specific operations, the government also benefits from the regional HIV/AIDS project. There are currently four projects under preparation: (i) Strengthening the National Statistical System, (ii) Bishkek-Osh Infrastructure, (iii) Agricultural Investment and Services (ASSP- 2), and (iv) Economic Management TA.

4. International Finance Corporation (IFC) Program and Portfolio. Since becoming a member of IFC in 1993, the Kyrgyz Republic has received commitments totaling nearly US\$57 million from IFC's own funds to finance twelve projects in the financial, oil and gas, food and beverage, and pulp and paper sectors. The committed IFC portfolio as of July 1 , 2007 stands at US\$15 million, with US\$13 million disbursed (77 percent in financial markets, 9 percent in general manufacturing and 14 percent in agribusiness). The largest investment in the existing portfolio was the Kumtor Gold Mine, with further investments in a packaging plant "Altyn-Ajydar," pasta plant "Akun" and four financial sector projects 
Demirbank, KICB, FINCA and Bai-Tushum. Under the framework of the Medium- and Small-Enterprises Fund (MSEF) joint project with EBRD, IFC has provided credit lines to local banks such as AKB Kyrgyzstan, Ineximbank and Kazcommertsbank.

5. IFC has completed $\mathbf{1 4}$ technical assistance projects in the areas of: (i) institutional and capacity building in the financial sectors including leasing, microfinance, (ii) creating favorable business environment for SMEs, (iii) improving investment climate, and (iv) developing capacity building for tourism. IFC PEP Central Asian Primary Market Development Project was launched in 2005, and the second phase of IFC PEP Central Asian Regional Leasing Project has also started. By the end of 2007, IFC plans to start a regional TA project to improve corporate governance in enterprises of Central Asia including Kyrgyzstan.

6. Multilateral Investment Guarantee Agency (MIGA) has supported private sector development in the Kyrgyz Republic by extending guarantees to foreign direct investments in four projects in the manufacturing, services, and mining sectors. MIGA's current portfolio consists of two projects, financed by Austrian and Italian investors, in support of the country's services sector. The combined gross exposure from these projects is US $\$ 14.8$ million. Two claims have been filed relating to projects guaranteed by MIGA. One of them is the Kyrgyz Airlines project in which the Government of the Kyrgyz Republic cancelled the airline's license to operate, alleging that the investor breached material obligations under the license agreement. The case is in arbitration in London. The second dispute relates to the Manas Management Company project which handles the catering and cargo operations of the Manas International Airport in Bishkek. MIGA is seeking to settle the dispute through mediation, and is in close contact with both the Kyrgyz authorities and the investors for this purpose. Recently, a draft settlement agreement was discussed in detail by the two parties at a mediation facilitated by the Agency. At present, the Government is reviewing some terms relating to the settlement and the investors are awaiting outcome. Due to the recent changes in the Government the process is taking much longer than anticipated. The total amount of foreign direct investment facilitated by MIGA guarantees is over US\$360 million. At present, there are no projects involving the Kyrgyz Republic in MIGA's FY07 pipeline.

\section{World Bank contacts:}

Roland Clarke (rclarke@worldbank.org), Sr. Country Economist. Phone No. (202) 458-8156 Dinara Djoldosheva (ddjoldosheva@worldbank.org), Sr. Country Officer.

Phone No. (996312) 610650 


\section{ANNEX III. KYRGYZ REPUBLIC—RELATIONS WITH THE ASIAN DEVELOPMENT BANK (ADB)}

(As of September 30, 2007)

1. ADB has been the second largest development partner in the Kyrgyz Republic since its joining in 1994. The current Country Strategy and Program Update (CSPU) for 200608 (approved in November 2005) confirms ADB priorities of (i) investing in agriculture, which is key to pro-poor growth; (ii) reforming the financial sector to stimulate domestic savings and investment; (iii) improving trade and road linkages with regional markets; and (iv) selectively supporting human development, particularly basic education and early childhood development.

2. Currently, the ADB together with other major bilateral and multilateral agencies (DFID, SDC/seco, UN, and WB), providing assistance to the Kyrgyz Republic, is on a final stage of developing a new Joint Country Support Strategy (JCSS) for the period 2007-10. It is closely aligned with the Government's development goals and is scheduled for Board consideration in October 2007. The priority areas for JCSS are identified as its main pillars: (i) promoting private sector and economic growth, (ii) good governance and reducing corruption, and (iii) improving health, education and other social services.

3. As of 30 September 2007, the country has received 26 loans and 4 grants for a total amount of $\$ 644$ million. Seven out of the 26 loans are program loans totaling $\$ 199.5$ million provided to support policy reforms to facilitate the transition to a market economy. The remaining 19 are project loans and 4 project grants totaling $\$ 444.5$ million provided to support various investment activities. At present, 10 loans and 2 grants with approved amount of $\$ 228.8$ million are ongoing, These loans and grants have an un-disbursed balance of \$17.7 million as of September 30, 2007. 2 grants in amount of \$20 million is awaiting effectiveness. All these loans were provided on concessional terms from the Bank's special fund resources-Asian Development Fund (ADF). The Kyrgyz Republic has also received 7 JFPR Grants amounting to $\$ 7$ million. The transport and communications sectors account for the largest share of ADB assistance, followed by the multisector, and law, economics and public policy.

4. In addition to loans and grants, ADB had provided 68 technical assistance (TA) projects amounting to $\$ 39.7$ million as of today. Of these, 19 are project preparatory TAs amounting to $\$ 12.7$ million and the remaining 49 TAs for $\$ 27$ million are advisory TAs for capacity building, policy advice, institutional strengthening and training..

5. The performance of ADB's portfolio is generally satisfactory, although one loan is rated at risk. The scarcity of budgetary resources, and ceilings on the externally funded PIP constituted the biggest risks to the country portfolio. ADB and the World Bank have thus sought the removal of quarterly disbursement ceilings, which delay project implementation. 
In August 2005, IMF agreed to be more flexible in determining annual targets for the PIP, which is expected to improve portfolio performance.

6. ADB's annual lending began with $\$ 40$ million in 1994 and reached the peak level of $\$ 89.2$ million by 1997 . Thereafter, lending levels fell slightly and hovered between $\$ 65$ million and \$75 million through 2001. ADB's average annual lending level during 2002 and 2003 was $\$ 15.25$ million. This was much lower than the lending levels in the past, largely due to the government's policy of restrained borrowings as part of its debt management strategy which envisaged a reduction in the size of the largely externally funded PIP from about 6 percent of GDP in 2001 to about 3.1 percent of GDP by 2006. The level of assistance for the block of two year 2005-06 was $\$ 60.8$ million. The allocation for the block of two years $2007-08$ is determined at $\$ 55$ million. This program will be reviewed, based on the availability of ADF funds and the rules governing grants, to make it consistent with the Government's debt reduction strategy and the limits on the PIP.

7. The allocation of ADF resources to the country is based on the government's attainment of performance targets (triggers) in five areas: (a) making steady progress in macroeconomic management and structural reforms in the financial sector, and customs administration; (b) making progress in prioritizing on-going PIP projects; (c) adhering to the national debt reduction strategy; (d) finalizing the Country Development Strategy 2007-2010 (formerly called the NPRS); and (e) implementing a package of legal and judicial reforms for improving the investment climate for the private sector. Since 2005, up to 50 percent of ADF assistance to the country come in the form of grants. The Bank is currently considering providing assistance on 100 percent grant basis.

8. The Kyrgyz Republic is one of the pilot countries selected for harmonization and alignment of donor procedures at the Rome Conference on harmonization held in February 2002. ADB coordinates its activities closely with the EBRD, IMF, IsDB, World Bank, the UN System, and bilateral donors at all levels of development cooperation. There have been significant strides forward in aid coordination since the last CG meeting held in Bishkek in November 2002, when both the Government and the donors agreed to focus on improving significantly coordination efforts. Since then efforts are being made to share sectoral and operational information and better coordinate lending and technical assistance activities. Since 2003, ADB and World Bank, which together account for over 75 percent of the PIP, conducts a joint portfolio review.

9. Kyrgyz Resident Mission participated actively in the harmonization working group and contributed to the development of the National Action Plan for Harmonization which was approved by the Government in February 2005. The areas identified for harmonization in the immediate future are: (a) procedures for procurement of goods and services; (b) financial management and monitoring of projects; and (c) project implementation units. World Bank and ADB procurement documentation has been harmonized in these areas. 


\section{ANNEX IV. KYRGYZ REPUBLIC-RELATIONS WITH THE EUROPEAN BANK FOR RECONSTRUCTION AND DEVELOPMENT (EBRD)}

(As of September 30, 2007)

1. The EBRD facilitates the transition to a market-based economy through its direct support for private sector investment and key infrastructure, and targeted technical assistance. Under the Early Transition Countries' Initiative (ETCI) introduced in 2005, the Bank is able to more innovative respond to the Kyrgyz economic requirements. Therefore, the Bank is considering smaller, "more difficult" projects. The ETCI also foresees technical cooperation (TC) to support investment development.

2. According to the new Strategy for the Kyrgyz Republic approved in June 2007, the Bank's priorities are to: (a) fostering the private sector; (b) improving the competitiveness of the financial sector; (c) support for critical infrastructure; and (d) strengthening the policy dialogue to improve the investment climate and support reform efforts.

3. As of September 2007, the Bank had approved 52 projects (including restructurings) with total financing comprising around $€ 758$ million of investment. The Bank has provided more than $€ 187$ million of this amount.

4. During the past three years, the Bank expanded its activities in the financial sector to include:

- The Kyrgyz Micro and Small Enterprises Financing Facility (MSEFF). As of 30 September, 2007, around \$294 million (cumulative) had been disbursed supporting 101,480 loans to small- and medium-size enterprises. Up to date MSEFF has helped to create or sustain around 145,653 jobs. The Bank works with seven participating commercial banks and also with nonbanking institutions-Bai-Tushum, Aiyl Bank, FINCA, Kompanion and Frontiers.

- In 2007, the Bank has signed \$2 million with two nonbanks institutions Frontiers and Kompanion. And

- In 2006, the Bank signed a $\$ 1$ million Guarantee in favour of Bai-Tushum to a local bank in Kyrgyz Republic which will provide local currency funds for on-lending to MSEs and solidarity groups.

- Equity investments in Ineximbank, Demir Bank, and KICB.

- Expansion of Trade Facilitation Program (TFP). Five banks are participants in the TFP.

- In 2004, the Bank signed a cofinancing facility of \$4 million to KICB. This new ETC product is provided to meet financing needs of emerging medium-sized private companies. Two sub-loans are signed to date for $€ 1.4$ million. 
Other major investments by the Bank during its operations in KR include:

- \$20 million loan and \$10 million sub debt, since converted into \$17 million equity participation in Centerra Gold (the Bank's senior loan have been fully repaid).

- Loan to Hyatt-Regency Hotel, \$6.3 million in 1997.

- Loan to Interglass plant, \$6 million in 2004.

- Loan to Limatex (cotton-processing plant in Djalal-Abad), \$1 million in 2005.

- Loan to Raduga Invest (resort on Issyk-Kul Lake), \$6 million in 2005.

- Loan to Karven Four Seasons (resort on Issyk-Kul Lake), \$3.8 million in 2006.

Although the Bank is currently unable to provide loans with sovereign guarantee the Bank continues to monitor public sector projects:

- Modernization of the telecommunications network (\$7.9 million).

- Two projects to upgrade electricity transmission networks in Issyk-Kul and Talas regions (\$63 million combined).

The Bank is working with the Government to consider non sovereign financing in-roads and railroads, telecoms, gas pipeline and other infrastructure projects.

5. The Bank also implements grant-funded TC to support its investment portfolio, including the financial sector (including MSFF consultants among others), natural resources/environment, agribusiness and infrastructure. Recent TCs include:

- In telecoms, to advise on key reforms, including intercapacity access arrangements;

- Training for judges in commercial law;

- Investor protection reform initiative;

- Roll out of the Business Advisory Service and Turn Around Management programs, providing consulting services to viable businesses.

6. Finally, the Bank maintains an active dialogue with the government. The Bank was instrumental in founding the International Business Council, which is devoted to working with the government on improving the investment climate. The Bank launched a new Investors Council under the President to address business concerns and improve legislative base. In particular, Bank has provided guidance on legal reforms, such as the newly revised Law on Pledge. 
Annex V. Kyrgyz Republic-Technical Assistance Provided by the Fund February 2003-September 2007

\begin{tabular}{|c|c|c|c|}
\hline Dept. & Subject/Identified Need & Timing & Counterpart \\
\hline \multirow[t]{6}{*}{ FAD } & $\begin{array}{l}\text { Improving the Effectiveness of the Large } \\
\text { Taxpayer Unit }\end{array}$ & $\begin{array}{l}\text { February 24- } \\
\text { March 7, 2003 }\end{array}$ & Ministry of Finance \\
\hline & $\begin{array}{l}\text { Treasury Management Information } \\
\text { System }\end{array}$ & July 21-29, 2003 & Ministry of Finance \\
\hline & VAT on agriculture & November 3-11, 2003 & Ministry of Finance \\
\hline & Priorities for Tax Administration Reform & July 22-August 5, 2004 & Ministry of Finance \\
\hline & $\begin{array}{l}\text { Supporting Tax Administration Reform } \\
\text { and installing new Expert Advisor }\end{array}$ & January 16-28, 2006 & $\begin{array}{l}\text { Prime Minister's } \\
\text { office }\end{array}$ \\
\hline & $\begin{array}{l}\text { Fiscal ROSC Reassessment (Fiscal } \\
\text { Transparency Module) }\end{array}$ & September 11-25, 2007 & Ministry of Finance \\
\hline \multirow[t]{9}{*}{$\begin{array}{l}\mathrm{MFD} / \\
\mathrm{MCM}\end{array}$} & $\begin{array}{l}\text { Review of the Capital Adequacy and } \\
\text { Dividend Arrangements for the National } \\
\text { Bank of the Kyrgyz Republic }\end{array}$ & August 18-28, 2003 & $\begin{array}{l}\text { National Bank of the } \\
\text { Kyrgyz Republic }\end{array}$ \\
\hline & $\begin{array}{l}\text { Review of Debt Restructuring Operation } \\
\text { and } 2003 \text { Financial Reporting }\end{array}$ & $\begin{array}{l}\text { October 28-November } 10 \\
2003\end{array}$ & $\begin{array}{l}\text { National Bank of the } \\
\text { Kyrgyz Republic }\end{array}$ \\
\hline & $\begin{array}{l}\text { Monetary Operations, Banking System } \\
\text { Development, and Central Bank } \\
\text { Autonomy }\end{array}$ & September 13-23, 2004 & $\begin{array}{l}\text { National Bank of the } \\
\text { Kyrgyz Republic }\end{array}$ \\
\hline & $\begin{array}{l}\text { Review of NBKR Debt Restructuring } \\
\text { Arrangements, Options for Deepening } \\
\text { Financial Markets and Amendments to } \\
\text { the NBKR Law }\end{array}$ & December 7-18, 2004 & $\begin{array}{l}\text { National Bank of the } \\
\text { Kyrgyz Republic }\end{array}$ \\
\hline & Payments System & $\begin{array}{l}\text { January } 25-\text { February } 7,2005 \text {, } \\
\text { April } 12-25,2005 \text {, and } \\
\text { October } 18-27,2005, \\
\text { February } 20-\text { March } 5,2006\end{array}$ & $\begin{array}{l}\text { National Bank of the } \\
\text { Kyrgyz Republic }\end{array}$ \\
\hline & Bank Supervision and Regulation & $\begin{array}{l}\text { February } 23-\text { March } 8,2005 \text {, } \\
\text { May } 18-28,2005, \text { July } 17-28 \text {, } \\
2005 \text {, October } 02-13,2005 \text {, } \\
\text { January } 15-26,2006 \text {, } \\
\text { February } 12-23,2006 \text {, } \\
\text { March } 20-30,2006\end{array}$ & $\begin{array}{l}\text { National Bank of the } \\
\text { Kyrgyz Republic }\end{array}$ \\
\hline & FSAP update & $\begin{array}{l}\text { September 5-15, } 2005 \\
\text { October } 10-23,2006\end{array}$ & $\begin{array}{l}\text { National Bank of the } \\
\text { Kyrgyz Republic }\end{array}$ \\
\hline & $\mathrm{AML} / \mathrm{CFT}$ & April 19-25, 2006 & $\begin{array}{l}\text { National Bank of the } \\
\text { Kyrgyz Republic }\end{array}$ \\
\hline & Government Securities/Money Markets & $\begin{array}{l}\text { August 25-30, } 2006 \\
\text { June 25-July 5, } 2007\end{array}$ & $\begin{array}{l}\text { National Bank of the } \\
\text { Kyrgyz Republic }\end{array}$ \\
\hline
\end{tabular}


Annex V. (Concluded) Kyrgyz Republic-Technical Assistance Provided by the FUND

February 2003-September 2007

\author{
Dept. Subject/Identified Need \\ LEG Update of the AML/CFT Legislation \\ (jointly with MFD) \\ Review of Bank Legislation \\ Review of Tax Legislation
}

Assisting in drafting Tax Code

AML/CFT Follow-up

AML/CFT Follow-up

STA

SDDS Subscription

Balance of Payments Statistics

Monetary and Financial Statistics

\section{Timing}

February 5-11, 2004

March 1-4, 2004

April 26-May 6, 2004

July 27-August 5, 2004

December 4-10, 2005

July 2-6, 2007

September 3-6, 2007

January 28-February 5, 2004

March 15-29, 2004

April 27-May 11, 2004

\section{Counterpart}

National Bank of the Kyrgyz Republic

National Bank of the Kyrgyz Republic

Ministry of Finance

Prime Minister's office

National Bank of the Kyrgyz Republic

National Bank of the Kyrgyz Republic and Financial Intelligence Unit

National Statistical Committee

National Bank of the Kyrgyz Republic

National Bank of the Kyrgyz Republic

\section{List of Resident Advisors}

MFD

MFD

MCM
Banking Supervision/Restructuring Advisor

Public Debt Policy and Management

Debt Management and Development of Government Securities Management
Mr. Svartsman

Mr. Azarbayejani

Mr. Riecke

August 2009
August 2006-

January 2004

January 2005

December 2002-

December 2004 


\section{ANNEX VI. KYRGYZ REPUBLIC-STATISTICAL ISSUES}

\section{General framework}

1. Data provision is adequate for surveillance. The three institutions responsible for collecting, compiling and disseminating macroeconomic statistics - the National Statistics Committee (NSC), the ministry of economy and finance (MOF), and the National Bank of the Kyrgyz Republic (NBKR) - have legal and institutional environments that support statistical quality, and their respective staff are well-versed in current methodologies. Unlike staff resources, however, computer and financial resources are generally not commensurate with current needs and therefore constrain statistical development, especially for the NSC.

2. The NSC maintains a comprehensive and regularly updated website with data that largely incorporate international methodological recommendations and adequate coverage and timeliness (http://www.stat.kg). In February 2004, following improvements in compilation and dissemination of the reserves template and external debt data, the Kyrgyz Republic subscribed to the SDDS.

3. A data ROSC mission in November 2002 assessed the data dissemination practices against the GDDS and undertook an in-depth assessment of the quality of national accounts, prices, government finance, monetary, and balance of payments statistics. The mission concluded that the quality of the macroeconomic statistics had improved significantly in the last few years. The authorities had established a good track record of implementing recommendations of past technical assistance and had demonstrated commitment to pursue plans and programs to further improve their statistics. The mission recommended that a program of regular intersectoral consistency checks be introduced to reduce the sometimes significant unexplained discrepancies between the government finance, monetary, and balance of payments datasets. The authorities' response to the data ROSC (posted on the IMF website (www.imf.org/external/np/rosc) includes an update on the status of implementation of the ROSC recommendations.

\section{National accounts}

4. In general, dissemination of national accounts statistics is timely. Technical assistance has been received from the IMF, EUROSTAT, OECD, the World Bank, and bilateral donors. While significant progress has been made in improving the national accounts estimation process, problems persist regarding the quality of the source data, due mainly to excessively tight collection deadlines associated with the release schedule. Efforts are needed to improve the quality of the source data for quarterly GDP estimates. Moreover, subannual national accounts are still prepared on a cumulative basis rather than by discrete time periods. Difficulties also remain in properly estimating the degree of underreporting, especially in the private sector. To improve the coverage and reliability of primary data, work has been undertaken to introduce sampling procedures. Improved sampling procedures have been adopted for household surveys and new report forms have been introduced for the 
enterprise survey. The NSC has established a division of sample surveys, which would assist in improving the sampling techniques.

\section{Prices, wages, and employment}

5. The concepts and definitions used in the consumer price index (CPI), which has been published since January 1995, are broadly consistent with international standards. The price index covers all urban resident households of all sizes and income levels, but excludes rural households, which comprise the majority of the population. The ROSC mission recommended that the authorities expand the coverage of the CPI to include rural households.

6. The producer price index (PPI), which has been published since October 1996, is compiled broadly in accordance with international standards, although its coverage needs to be improved. The coverage of the PPI was broadened in May 1997 and is expected to be further expanded in the coming years.

7. Progress has been made in computing unit value indices for imports and exports. Work continues with regard to computation of these indices using a standard index presentation and the development of an export price index. However, problems in customs administration have led to incomplete coverage of trade and the lack of an appropriate valuation system. Moreover, the data processed by customs have suffered due to the use of an outdated computer software system.

8. Problems exist in the compilation of the average wage, especially with respect to the valuation of payments in kind and the coverage of the private sector. Monthly and annual data are not comparable because of different coverage and classifications. These problems extend to employment data as well. The coverage of unemployment includes an estimate of unregistered unemployed.

\section{Fiscal accounts}

9. The scope of central government statistics falls short of international standards because it excludes data for the Social Fund and the externally financed Public Investment Program (these data are published separately). Other limitations involve the exclusion of financial transactions with domestic banks and the discrepancies between the deficit and financing data. While revenue and expenditure data generally accord with the GFSM 1986, there are misclassifications in both categories (for example, some nontax revenues are classified as taxes, and certain expenditure items are misclassified in the budget and treasury accounts). Monthly GFS data for IFS publication have been reported up to August 2007. The latest data for the GFS Yearbook were for 2006, covering general government and its subsectors and were compiled using the GFS Manual 2001 analytical framework. 
10. The provision of data on public external debt service has improved. Data on actual debt service, guaranteed debt service, outstanding debt and revised debt projections, are provided on a monthly basis. The quality (including timeliness) of external debt data is adequate. The External Debt Division of the MOF is now solely responsible for monitoring external debt, and this division has benefited from on-site training provided by a Swissfinanced long-term consultant and the computerization of its database.

\section{Monetary sector}

11. The 2002 data ROSC mission found that: (a) the residency criterion was not uniformly applied, as the currency denomination was used to classify some transactions with foreign and domestic units; (b) deposits with banks in liquidation were included in broad money; and (c) source data did not provide sufficient information for a more detailed sectoral breakdown (e.g., subsectorization of nonbank institutions as recommended in the Monetary and Financial Statistics Manual (MFSM)).

12. An STA mission on monetary and financial statistics visited Bishkek during April 27-May 11, 2004 to (a) follow up on the implementation of the ROSC recommendations; (b) expand the institutional coverage of the broad money survey; and (c) assist the NBKR in implementing the methodology spelled out in the MFSM. It found that the NBKR had made substantial progress in implementing ROSC recommendations pertaining to monetary statistics. To address the outstanding issues, the mission further recommended that the NBKR (a) improve the basic source data to allow for proper classification of the transactions with foreign and domestic units; (b) fully implement the MFSM's methodology concerning accrual accounting; (c) exclude deposits with banks in liquidation from monetary aggregates and classify them as restricted deposits; and (d) set up a working group to follow up on consistency between monetary and balance of payments statistics. The mission also recommended expanding the current broad money survey to include the accounts of credit unions and microfinance companies.

13. Monthly monetary data for IFS publication are reported on a regular and timely basis. Since December 2002, monetary data have been reported electronically to STA. In 2005, the NBKR began reporting its monetary data to STA using Standardized Report Forms, which are designed in accordance with the MFSM's methodology.

\section{External sector}

14. Data on the balance of payments and international investment position are compiled and disseminated on a quarterly basis. The 2002 data ROSC mission noted that the compilation of balance of payments statistics broadly follows the Balance of Payments Manual, Fifth Edition (BPM5). The NBKR has good arrangements with other agencies to ensure timely data flow. However, because of legal issues related to secrecy provisions, high value transactions cannot be verified with respondents, limiting the ability to cross-check the 
accuracy of data. Although the data collection program has been expanded in the recent past, coverage deficiencies remain with respect to trade, services, and foreign direct investment. The NBKR enterprise surveys lack an up-to-date register and have inadequate coverage of enterprises, particularly those in free economic zones. There is also a need to improve compilation procedures for achieving temporal consistency of data, and investigating and reconciling discrepancies.

15. The NSC conducts a quarterly sample survey for the estimation of shuttle trade, and uses customs records on the number of people crossing the border with CIS countries to derive the sample. The State Customs Inspectorate has introduced the customs receipt order for shuttle traders that simplifies and improves recording of imports of goods by shuttle traders. However, the high value limits applied for free import of goods by individuals have fostered a large shuttle trade, which has complicated estimation of this activity.

16. An STA mission on balance of payments statistics was in Bishkek during March1529, 2004 to address compilation issues, and to assess training needs. The mission noted that while progress had been made in several areas, further improvements were needed in the international transactions reporting system; data sampling methods; and data validation and coverage, particularly on trade, services, private sector external debt, and foreign direct investment. The mission developed a questionnaire for collecting data on foreign direct investments and provided guidelines on the collection of data on external debt. 


\section{Kyrgyz Republic: Table of Common Indicators Required for Surveillance} (As of October 23, 2007)

\begin{tabular}{|c|c|c|c|c|c|c|c|}
\hline & \multirow[t]{2}{*}{$\begin{array}{l}\text { Date of latest } \\
\text { observation }\end{array}$} & \multirow[t]{2}{*}{$\begin{array}{l}\text { Date } \\
\text { received }\end{array}$} & \multirow[t]{2}{*}{$\begin{array}{c}\text { Frequency } \\
\text { of } \\
\text { Data }^{6}\end{array}$} & \multirow[t]{2}{*}{$\begin{array}{c}\text { Frequency } \\
\text { of } \\
\text { Reporting }\end{array}$} & \multirow[t]{2}{*}{$\begin{array}{l}\text { Frequency of } \\
\text { publication }^{6}\end{array}$} & \multicolumn{2}{|c|}{ Memo Items: } \\
\hline & & & & & & $\begin{array}{c}\text { Data Quality- } \\
\text { Methodological } \\
\text { soundness }^{7} \\
\end{array}$ & $\begin{array}{c}\text { Data Quality- } \\
\text { Accuracy and } \\
\text { reliability }^{8} \\
\end{array}$ \\
\hline Exchange Rates & $10 / 22 / / 07$ & $10 / 23 / 07$ & $\mathrm{D}$ & $\mathrm{D}$ & W & & \\
\hline $\begin{array}{l}\text { International Reserve Assets and Reserve } \\
\text { Liabilities of the Monetary Authorities }{ }^{1}\end{array}$ & $10 / 4 / 07$ & $10 / 9 / 07$ & M & M & M & & \\
\hline Reserve/Base Money & $10 / 23 / 07$ & $10 / 24 / 07$ & $\mathrm{D}$ & $\mathrm{D}$ & M & LO, O, LO, LO & $\begin{array}{c}\mathrm{LO}, \mathrm{O}, \mathrm{O}, \mathrm{LO} \\
\mathrm{LO}\end{array}$ \\
\hline Broad Money & $8 / 30 / 07$ & $9 / 14 / 07$ & M & M & M & & \\
\hline Central Bank Balance Sheet & $10 / 23 / 07$ & $10 / 24 / 07$ & D & $\mathrm{D}$ & $\mathrm{M}$ & & \\
\hline $\begin{array}{l}\text { Consolidated Balance Sheet of the Banking } \\
\text { System }\end{array}$ & $8 / 31 / 07$ & $9 / 14 / 07$ & M & M & M & & \\
\hline Interest Rates ${ }^{2}$ & $10 / 04 / 07$ & $10 / 09 / 07$ & W & W & W & & \\
\hline Consumer Price Index & $9 / 30 / 07$ & $10 / 10 / 07$ & M & M & M & $\mathrm{O}, \mathrm{LO}, \mathrm{O}, \mathrm{O}$ & $\begin{array}{c}\text { LO, LO, O, O } \\
\text { O }\end{array}$ \\
\hline $\begin{array}{l}\text { Revenue, Expenditure, Balance and } \\
\text { Composition of Financing }{ }^{3}-\text { General } \\
\text { Government }^{4}\end{array}$ & $8 / 31 / 07$ & $10 / 04 / 07$ & M & M & $\mathrm{Y}$ & O, LNO, LO, O & $\begin{array}{c}\text { LO, O, O, LO, } \\
\text { LO }\end{array}$ \\
\hline $\begin{array}{l}\text { Revenue, Expenditure, Balance and } \\
\text { Composition of Financing }{ }^{3} \text {-Central } \\
\text { Government }\end{array}$ & $8 / 31 / 07$ & $10 / 04 / 07$ & M & M & M & & \\
\hline $\begin{array}{l}\text { Stocks of Central Government and Central } \\
\text { Government-Guaranteed Debt }{ }^{5}\end{array}$ & $6 / 30 / 07$ & $8 / 25 / 07$ & M & M & $\mathrm{Y}$ & & \\
\hline External Current Account Balance & $6 / 30 / 07$ & $8 / 22 / 07$ & Q & Q & Q & LO, LO, LO, LO & $\begin{array}{l}\text { O, LO, LO, LO, } \\
\text { LO }\end{array}$ \\
\hline Exports and Imports of Goods and Services & $6 / 30 / 07$ & $8 / 22 / 07$ & Q & Q & Q & & \\
\hline GDP/GNP & $9 / 30 / 07$ & $10 / 10 / 07$ & M & M & M & $\mathrm{O}, \mathrm{O}, \mathrm{LO}, \mathrm{O}$ & $\begin{array}{c}\text { LO, LO, LO, O } \\
\text { O }\end{array}$ \\
\hline Gross External Debt & $6 / 30 / 07$ & $8 / 25 / 07$ & M & M & Y & & \\
\hline
\end{tabular}

\footnotetext{
${ }_{2}^{1}$ Includes reserve assets pledged or otherwise encumbered, as well as net derivative positions.

${ }^{2}$ Both market-based and officially determined, including discount rates, money market rates, rates on treasury bills, notes and bonds.

${ }^{3}$ Foreign and domestic financing only.

${ }^{4}$ The general government consists of the central government (budgetary funds, extra budgetary funds, and social security funds) and state and local governments.

${ }^{5}$ Including currency and maturity composition.

${ }^{6}$ Daily (D), Weekly (W), Monthly (M), Quarterly (Q), Annually (A), Irregular (I); Not Available (NA).

${ }^{7}$ Reflects the assessment provided in the data ROSC (published on November 2003, and based on the findings of the mission that took place during November 2002) for the dataset corresponding to the variable in each row. The assessment indicates whether international standards concerning concepts and definitions, scope, classification/sectorization, and basis for recording are fully observed (O), largely observed (LO), largely not observed (LNO), or not observed (NO).

${ }^{8}$ Same as footnote 7 , except referring to international standards concerning source data, statistical techniques, assessment and validation of source data, assessment and validation of intermediate data and statistical outputs, and revision studies.
} 



\title{
INTERNATIONAL MONETARY FUND
}

\section{KYRGYZ REPUBLIC}

\author{
Joint World Bank/IMF Debt Sustainability Analysis \\ Prepared by the staffs of the International Monetary Fund \\ and the World Bank \\ Approved by David Owen and Scott Brown (IMF) and \\ Cheryl Gray and Mark Thomas (World Bank)
}

November 2, 2007

The staff's low-income country debt sustainability analysis (LIC DSA) suggests that the Kyrgyz Republic's external debt continues to pose a burden on public finances. Furthermore, despite improvements in debt indicators since the timing of the last LIC DSA-upgrading the country to moderate risk of debt distress - the debt outlook remains vulnerable to exogenous shocks reversals of the prudent macroeconomic policies of recent years or slower structural reforms. ${ }^{1}$ Ensuring that debt indicators remain on a downward path will require that strong and sustained GDP and exports growth be complemented by careful debt management and donor support on concessional terms.

The DSA presented here was prepared jointly by Fund and World Bank staffs in consultation with the authorities, using the joint Bank-Fund Low-Income Country Debt Sustainability Framework (LIC DSF). The data on stock of external debt for end-2006 provided by the authorities were checked by staff for consistency against the end-2005 loanby-loan debt figures reconciled earlier with the creditor information. The macroeconomic assumptions reflect the framework underlying the current PRGF-supported program and staff projections through 2027. They have been updated to incorporate recent developments and changes to the medium-term outlook, but long-term projections were kept similar to the framework used in the last LIC DSA.

The framework assumes continuation of sound macroeconomic policies-including fiscal consolidation and prudent public debt management—as a basis for sustaining growth (Box 1). Further, growth would be underpinned by firm implementation of structural

\footnotetext{
1 The 2006 LIC DSA was prepared in the context of the 2006 Article IV consultation (Country Report No. $07 / 135)$.
} 
reforms outlined in the Country Development Strategy (CDS) to remove impediments to private investment and stimulate economic diversification. In addition, the framework factors

in the recent increase in reserves of the Kumtor goldmine and assumes that continued benign economic conditions in neighboring Russia, Kazakhstan, and China would help maintain export growth and the flow of remittances. The framework features average long-run GDP growth of $4 \frac{1}{2}$ percent on the back of robust exports growth, reflecting strong private investments spurred by improvements in business climate. The external current account deficit is slated for a steady improvement from a projected 18 percent of GDP in 2007 to 7 percent in 2027 and will continue to be financed primarily by private capital inflows, including FDI.

Macroeconomic assumptions underlying previous DSAs (excluding the 2006 LIC DSA) did not materialize. ${ }^{2}$ Because of the political events of March 2005 and the serious accident at the Kumtor gold mine in 2006, the 2004-06 GDP growth (annual average 3.2 percent) was weaker than the earlier projected figure of 5.6 percent. However, staff's forecast of exports and fiscal revenues proved conservative. Exports exceeded projections because strong external demand propped up nongold exports while higher gold price helped offset the sharp decline in gold output in 2006. Overperformance in revenues was the result of recent improvements in tax and customs administration. Furthermore, the som appreciated against the U.S. dollar faster than projected, contributing, along with the March 2005 Paris Club rescheduling agreement, to substantially lower debt ratios by end-2006 than anticipated at the time of earlier DSAs.

\section{Structure of external debt}

\section{The Kyrgyz Republic's nominal stock of} public and publicly guaranteed external debt declined from 78 percent of GDP in 2005 to 70 percent in 2006. In present value terms, this is equivalent to $\$ 1,257$ million (441/2 percent of GDP), of which 71 percent is owed to IFIs and the remaining 29 percent to bilateral creditors. Following the March 2005 Paris Club rescheduling, the authorities have reached debt restructuring agreements with all Paris Club
Kyrgyz Republic: NPV of external debt (Total: 1,257 million, end-2006).

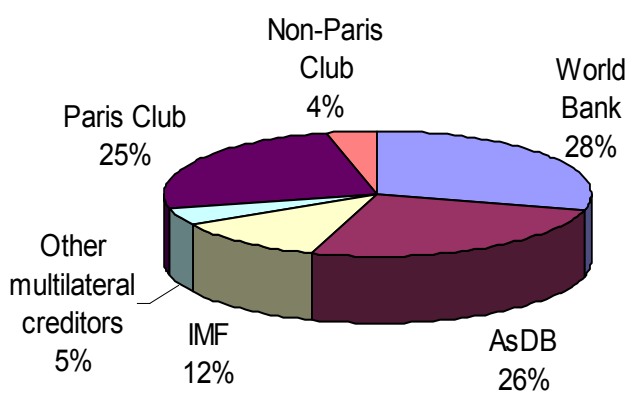

\footnotetext{
${ }^{2}$ The assessment has been carried out in response to the Board's endorsement of the staff's recommendations on adapting the LIC DSF in a joint IMF/World Bank policy paper (Applying the Debt Sustainability Framework for Low-Income Countries Post Debt Relief, November 6, 2006 (www.imf.org)). It is based on LIC DSAs prepared by the Fund staff for the 2004 Article IV consultation staff report (Country Report No. 05/47) and the request for the ongoing PRGF arrangement (Country Report No. 05/119).
} 
creditors, which granted 40 percent NPV reduction on most loans. However, despite the authorities' best efforts, agreements remain to be reached with a number of official bilateral creditors. 
External debt ratios have improved considerably over the past few years. The public external debt-to-GDP ratio has declined from a little under 100 percent in 2003 to 70 percent in 2006, while the NPV of the same debt to exports fell even more sharply, from 162 percent in 2003 to 91 percent in 2006. The decline in the ratios - notwithstanding the moderate real GDP growth-has been mainly the result of high growth of exports and U.S. dollar nominal GDP.

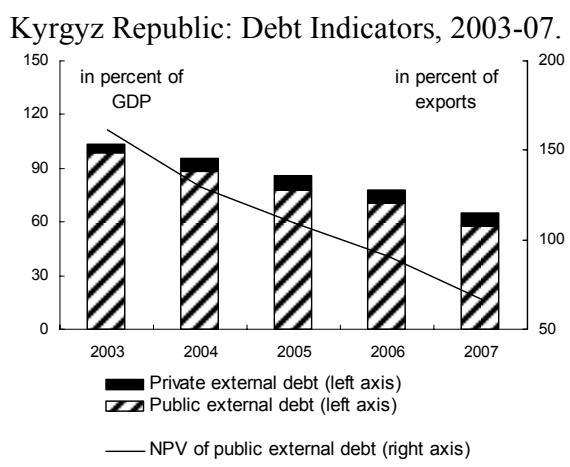
The external private debt ratio decreased in the early 2000s, but picked up in 2006 to about 8 percent of GDP, a trend staff expects to continue in the near future.

\section{External debt sustainability}

While the assumptions outlined in Box 1 underpin the baseline projections of debt sustainability indicators, staff conducted a series of stress tests to assess their sensitivity to less favorable scenarios. In addition to standard bound and stress tests embedded in the LIC DSA template, staff developed two Kyrgyz-specific alternative scenarios. Recognizing the key role of gold in exports, the first scenario gauges the impact on debt indicators of the permanently lower gold price throughout the projection period. In particular, it assumes that the price starts to diverge from the baseline path in 2008, deviating by as much as 25 percent from 2010 onwards. The scenario accounts for the second-round effects by assuming a slowdown in growth and FDI and slower currency appreciation in 2008-10. The second scenario assumes that the reduction in retirement age, initiated in 2007 , will not be reversed and will remain effective throughout the DSA horizon, resulting in an average annual pension expenditure growth of 11 percent from 2009 to $2027 .^{3}$ The additional financing needs would amount to $1 / 2$ percent of GDP in 2009 , rising steadily to more than $1 \frac{1}{2}$ percent of GDP by $2027 .{ }^{4}$

As noted below, the current debt burden places the Kyrgyz Republic at a moderate risk of debt distress. Nevertheless, the baseline scenario points to a cautiously favorable improvement in the external debt outlook over time. Already by end-2006, the NPV of debtto-exports and the NPV of debt-to-revenue ratios, at $903 / 4$ and 204 percent respectively, were

\footnotetext{
${ }^{3}$ This scenario can also be interpreted as reflecting the impact of a loose fiscal policy.

${ }^{4}$ According to the recently adopted law, the retirement age is being gradually reduced from 63 to 60 years old for men and 58 to 55 for women. Concerned with fiscal implications, the government has drawn plans to stop the reduction in the retirement age in 2008 by asking parliament to nullify the law or challenging it in the Constitutional Court. The staff's baseline scenario assumes that the law will be nullified or a pension reform to put the pension system on a sustainable footing will be implemented with the assistance of the World Bank.
} 
well below their policy-based indicative thresholds. ${ }^{5}$ Only the NPV of debt-to-GDP ratio is slightly above its relevant threshold of 40 percent in 2006, but by end-2007 it too is projected to fall below that mark. Over the DSA horizon, all sustainability ratios move steadily on a downward path underpinned by strong growth, fiscal consolidation, and prudent debt management. With the anticipated closure of the Kumtor gold mine in 2014-15, the ratios, particularly in relation to exports, would increase somewhat around that time, but would eventually fall back below the preclosure levels.

Debt service is expected to remain manageable throughout the DSA horizon. This reflects the high concessionality of both the outstanding multilateral debt and the new borrowing, as well as the debt relief delivered by Paris Club creditors in 2005. In sum, the debt service would average $3 \frac{1}{2}$ percent of exports ( $71 / 2$ percent of revenues) in the medium term, but hover at 51/4 percent of exports (10 percent of revenues) during the later stage of the projection period, driven by less concessional new borrowing and the repayment of the previously restructured bilateral debt.

Stress tests and alternative scenarios show the Kyrgyz Republic's debt sustainability as vulnerable to large shocks or less favorable assumptions. The NPV of debt-to-GDP ratio rises and stays above the threshold under many tests, while the NPV of debt-to-revenue is especially sensitive to assumptions on export growth, projections of nondebt creating inflows, and a combination of four standard tests (B5), breaching the respective threshold over the DSA horizon. However, the NPV of debt-to-exports ratio is particularly robust and breaches its threshold only under the combination test (B5). Debt service ratios prove relatively more resilient too, staying below their indicative levels in most cases. As with the solvency ratios, the combination of four standard tests (B5) has the most adverse impact on the debt service indicators. The additional country-specific scenario (A3) designed by staff shows that the debt situation would worsen in the event of a sharp permanent fall in gold price, but would nonetheless remain manageable. While all sustainability indicators deteriorate over the medium term, only the NPV of debt-to-GDP ratio would breach, albeit only briefly, the threshold. Similarly, the failure to reform the pension system (A4) would lead to a serious deterioration of debt ratios in the long term. However, only the NPV of debt-to-GDP ratio would exceed the threshold. Despite the sensitivity of the debt burden outlook to unfavorable conditions as evidenced from stress tests and alternative scenarios, staff's baseline assumptions appear realistic. The historical scenario-where key macro variables evolve according to their historic averages - points to a more benign debt outlook than the baseline scenario.

\footnotetext{
${ }^{5}$ The Kyrgyz Republic is rated as a medium performer based on the World Bank's Country Performance and Institutional Assessment Index. The relevant policy-dependent thresholds are 40 percent for the NPV of the debt-to-GDP ratio, 150 percent for the NPV of debt-to-exports ratio, 250 percent for the NPV of debt-torevenue ratio, 20 percent of the debt service-to-exports ratio, and 30 percent of the debt service-to-revenue ratio.
} 


\section{Box 1. Macroeconomic Assumptions 2007-27.}

Annual real GDP growth would average 41/2 percent, on the back of strong private investment, including FDI, spurred by improvements in business climate. The strong growth in the near term will be supported by a rebound in mining and the initial impact of reforms in the energy sector, while tourism-related services and a reformed energy sector would underpin measured but sustained long-run growth. Consistent with the assumption of conservative fiscal and monetary policies, long-term inflation would average 4 percent.

Following an accident in the Kumtor gold mine in 2006 , exports are slated to recover, growing by an average of 12 percent a year in the near term. In addition to normalization of Kumtor operations, this recovery would be underpinned by the start of mining in other major gold deposits and robust import demand from Russia and Kazakhstan, particularly for industrial and processed food products. As this growth pattern would keep exports vulnerable to a depletion of mining deposits, a sharp drop in world commodity prices, and natural disasters, export diversification efforts need to be directed to creating an enabling business environment to exploit the considerable export potential, particularly in tourism and hydroenergy. Long run projections assume that a sharp drop in gold output from the expected closure of the Kumtor mine in 2014-2015 will be moderated by gains in the tourism and energy sectors. In all, annual exports volume growth would average 5\%/4 percent over the DSA period, stabilizing at 5 percent by 2027.

Consistent with growth projections and expected FDI inflows, imports volume would grow at $43 / 4$ percent a year. They would continue to be sourced mainly from CIS trading partners and China, with oil products and consumer goods dominating the commodity structure.

The current account deficit is projected to narrow from projected 18 percent of GDP in 2007 to 7 percent in 2027. Buoyed by strong income growth in Russia and Kazakhstan, private transfers - mainly worker's remittances amounting to 25 percent of GDP in 2006 - will remain large, financing a significant share of the trade deficit. In the long-run, a projected narrowing in the current account deficit would be supported by fiscal consolidation and increased private savings.

Net FDI would remain stable at around 5 percent of GDP throughout the projection period. While in the near term FDI would be concentrated in traditional sectors, like mining and industry, business climate improvements should yield a more diversified structure of FDI in the outer years. The foreign loan-financed part of the Public Investment Program would initially decline from 2.2 percent of GDP at present to $13 / 4$ percent of GDP in 2013, but will then pick up to return to the current levels by 2027. International reserves would be kept at 4 months of imports.

Medium-term public borrowing — to finance the Public Investment Program and fill financing gaps-will be on highly concessional terms, primarily from IFIs. Over the DSA horizon, concessionality of new external public borrowing would gradually decline from around 45 percent in 2007-2012 to 18 percent in 2017-2027, as more borrowing will be contracted at less concessional terms from bilateral and commercial creditors.

The primary deficit is projected somewhat above 1 percent of GDP in 2007-2012, but will decline gradually, stabilizing around $1 / 2$ percent of GDP over the long term. State government revenues (excluding grants) are projected at around 241/2 percent of GDP in 2007-2011 and would remain broadly unchanged with respect to GDP. 
Debt service is expected to remain manageable throughout the DSA horizon. This reflects the high concessionality of both the outstanding multilateral debt and the new borrowing, as well as the debt relief delivered by Paris Club creditors in 2005. In sum, the debt service would average $3 \frac{1}{2}$ percent of exports ( $71 / 2$ percent of revenues) in the medium term, but hover at 51/4 percent of exports (10 percent of revenues) during the later stage of the projection period, driven by less concessional new borrowing and the repayment of the previously restructured bilateral debt.

Stress tests and alternative scenarios show the Kyrgyz Republic's debt sustainability as vulnerable to large shocks or less favorable assumptions. The NPV of debt-to-GDP ratio rises and stays above the threshold under many tests, while the NPV of debt-to-revenue is especially sensitive to assumptions on export growth, projections of nondebt creating inflows, and a combination of four standard tests (B5), breaching the respective threshold over the DSA horizon. However, the NPV of debt-to-exports ratio is particularly robust and breaches its threshold only under the combination test (B5). Debt service ratios prove relatively more resilient too, staying below their indicative levels in most cases. As with the solvency ratios, the combination of four standard tests (B5) has the most adverse impact on the debt service indicators. The additional country-specific scenario (A3) designed by staff shows that the debt situation would worsen in the event of a sharp permanent fall in gold price, but would nonetheless remain manageable. While all sustainability indicators deteriorate over the medium term, only the NPV of debt-to-GDP ratio would breach, albeit only briefly, the threshold. Similarly, the failure to reform the pension system (A4) would lead to a serious deterioration of debt ratios in the long term. However, only the NPV of debt-to-GDP ratio would exceed the threshold. Despite the sensitivity of the debt burden outlook to unfavorable conditions as evidenced from stress tests and alternative scenarios, staff's baseline assumptions appear realistic. The historical scenario-where key macro variables evolve according to their historic averages - points to a more benign debt outlook than the baseline scenario.

\section{Low-concessionality loans from bilateral creditors to finance large public investment projects continue to pose risk to the debt sustainability outlook. Although the} government has on many occasions reconfirmed its policy not to attract external loans with the grant element below 45 percent, influential political leaders and interest groups may advocate exceptions from the rule for "strategic" projects. Staff recognizes that the Kyrgyz Republic has large developmental needs, but considers paramount to lock in the recent progress in achieving debt sustainability. Even if the loans were to meet the 45 percent concessionality threshold, it would be important to ensure that the underlying projects are viable and market risks, including exchange rate risk, are accounted for, so as to safeguard debt sustainability. 


\section{Public debt sustainability}

External debt will continue to account for more than 90 percent of total public debt. Thus, as a percent of GDP, the drop in external debt will explain most of the change in the nominal stock of public debt which falls from 76 percent in 2006 to 30 percent in 2027 . Domestic debt consists of treasury paper, and foreign exchange-denominated loans, which account for 48 percent, 28 percent, and 24 percent of total domestic public debt in 2006, respectively.

Public debt sustainability is expected to improve considerably due to progress in tax and customs administration, as well as fiscal consolidation from reforms in the pension system and the civil service. Compared to the last DSA, there have already been significant improvements in public debt ratios in 2007 stemming from unanticipated revenue overperformance in import-related collections in the first three-quarter of the year. This revenue source is assumed to remain broadly stable as a share of GDP after 2008. Still, expenditure control will take up the slack in the medium term when pension and civil service reforms are expected to take effect. All in all, the DSA assumes a fiscal consolidation of around $3 / 4$ percent of GDP from 2007 to 2027. In the baseline scenario, the NPV of public debt-to-GDP is 42 percent in 2007 and drops to 25 percent in 2027. Meanwhile, the baseline ratio of NPV of debt-to-revenue declines from 157 percent in 2007 to 96 percent in 2027 and the baseline ratio of debt service-to-revenue ratio stays low at 9 percent in 2007 and 11 percent in 2027. Debt levels are however vulnerable to combined shocks to the economy; if real GDP growth and the primary balance are at historical averages, the NPV of debt-toGDP ratio rises steadily from 42 percent in 2007 to 82 percent in 2027 . The NPV of debt-torevenue ratio also increases to 322 percent by 2027 .

\section{Debt distress classification}

The Kyrgyz Republic is assessed to be at moderate risk of debt distress because, starting in 2007, all external debt indicators in the baseline are projected to stay below the indicative threshold over the DSA horizon. ${ }^{6}$ At 44 percent, only the NPV of external public debt-to-GDP ratio stands slightly above its indicative threshold of 40 percent at end2006, but it is forecast to fall below the mark in 2007. Moreover, under the baseline scenario, the debt service burden would remain well below the thresholds, reflecting the high concessionality of the external debt. Nevertheless, alternative scenarios and stress tests show that the external public debt indicators would approach or breach the thresholds if the Kyrgyz Republic were to experience an adverse exogenous shock or relax its prudent debt management policy.

\footnotetext{
${ }^{6}$ This classification is based on the guidelines set out in a joint IMF/World Bank policy paper (Operational Framework for Debt Sustainability Assessments in Low-Income Countries_-Further Considerations (www.imf.org)).
} 
If the debt classification were instead based on total public debt (not solely on external public debt), it would be downgraded to the high risk category of debt distress even though the total domestic debt accounts roughly to 10 percent of total public debt. The assessment in this DSA is based on comparing external debt indicators to the LIC DSF indicative thresholds that apply only to the external component of public debt. When domestic public debt is included, the baseline points to a less pronounced decline in ratios; in particular, the NPV of debt-to-GDP ratio remains above its threshold longer. 
Figure 1. Kyrgyz Republic: Indicators of Public and Publicly Guaranteed External Debt Under Alternative Scenarios, 2007-2027 1/
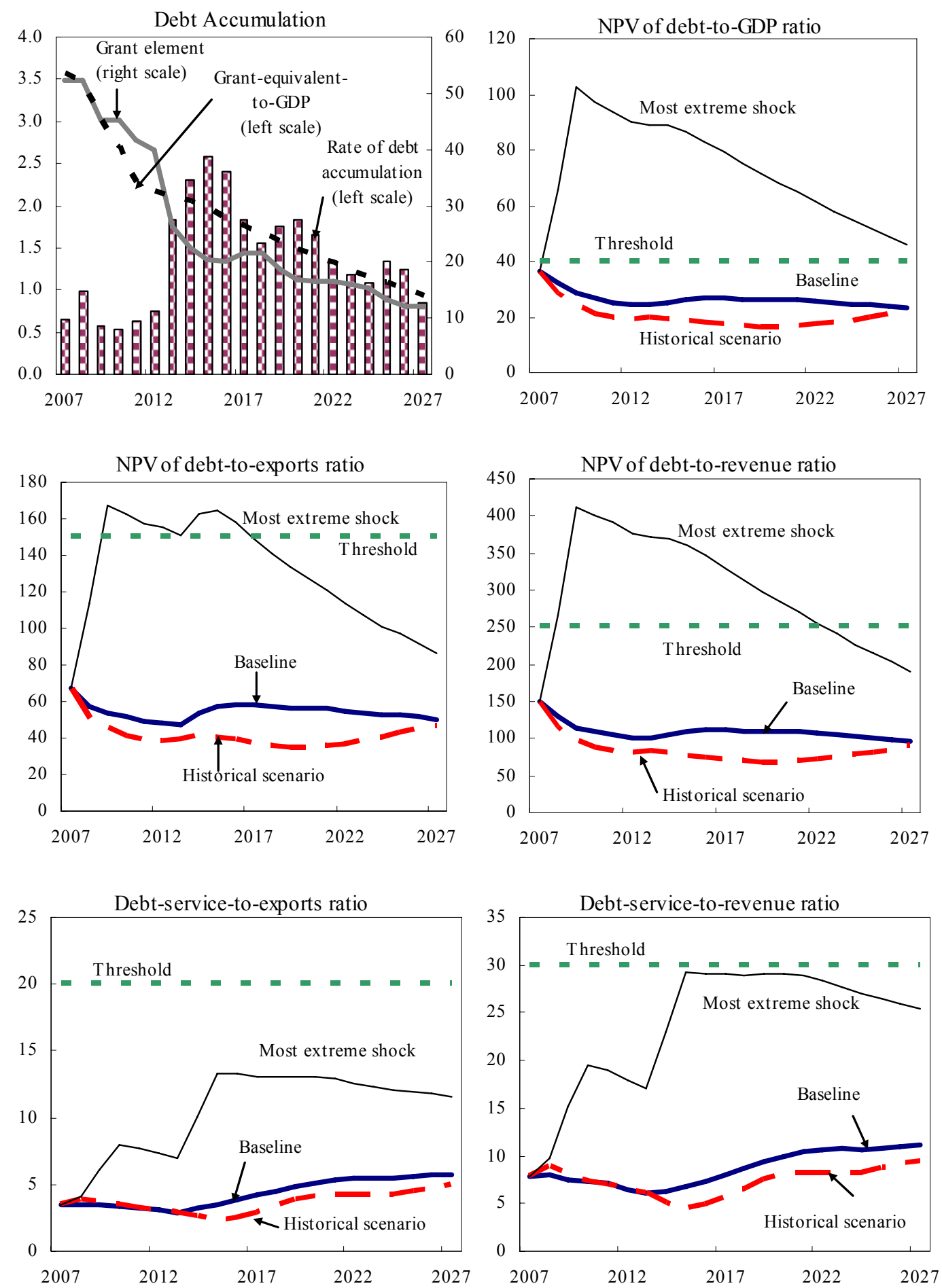

Source: Staff projections and simulations.

1/ Most extreme shock is shock that yields highest ratio in 2017. 
Figure 2. Kyrgyz Republic: Indicators of Public Debt Under Alternative Scenarios, 2007-2027 1 /
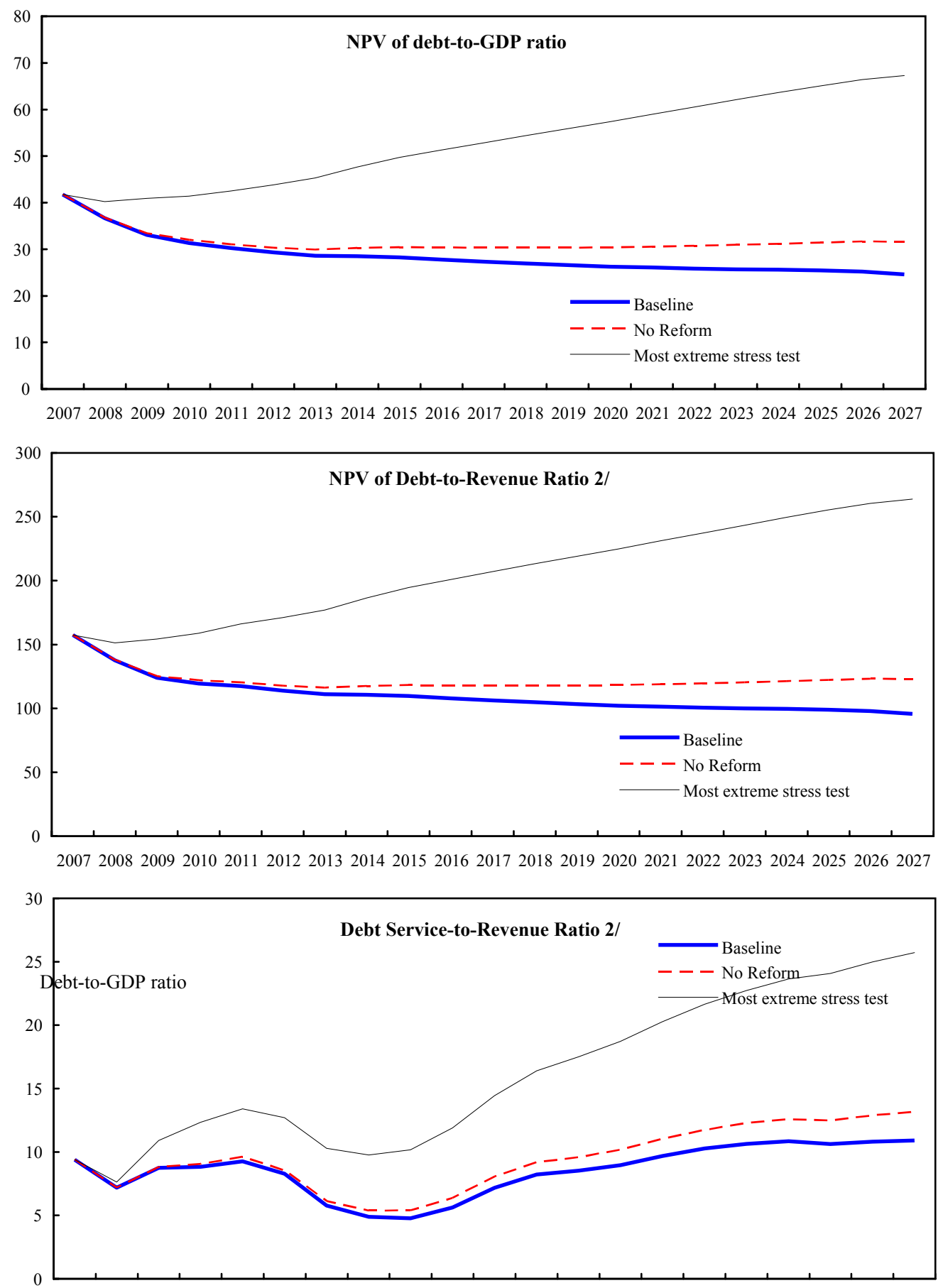

200720082009201020112012201320142015201620172018201920202021202220232024202520262027

Source: Staff projections and simulations.

1/ Most extreme stress test is test that yields highest ratio in 2017.

$2 /$ Revenue including grants. 


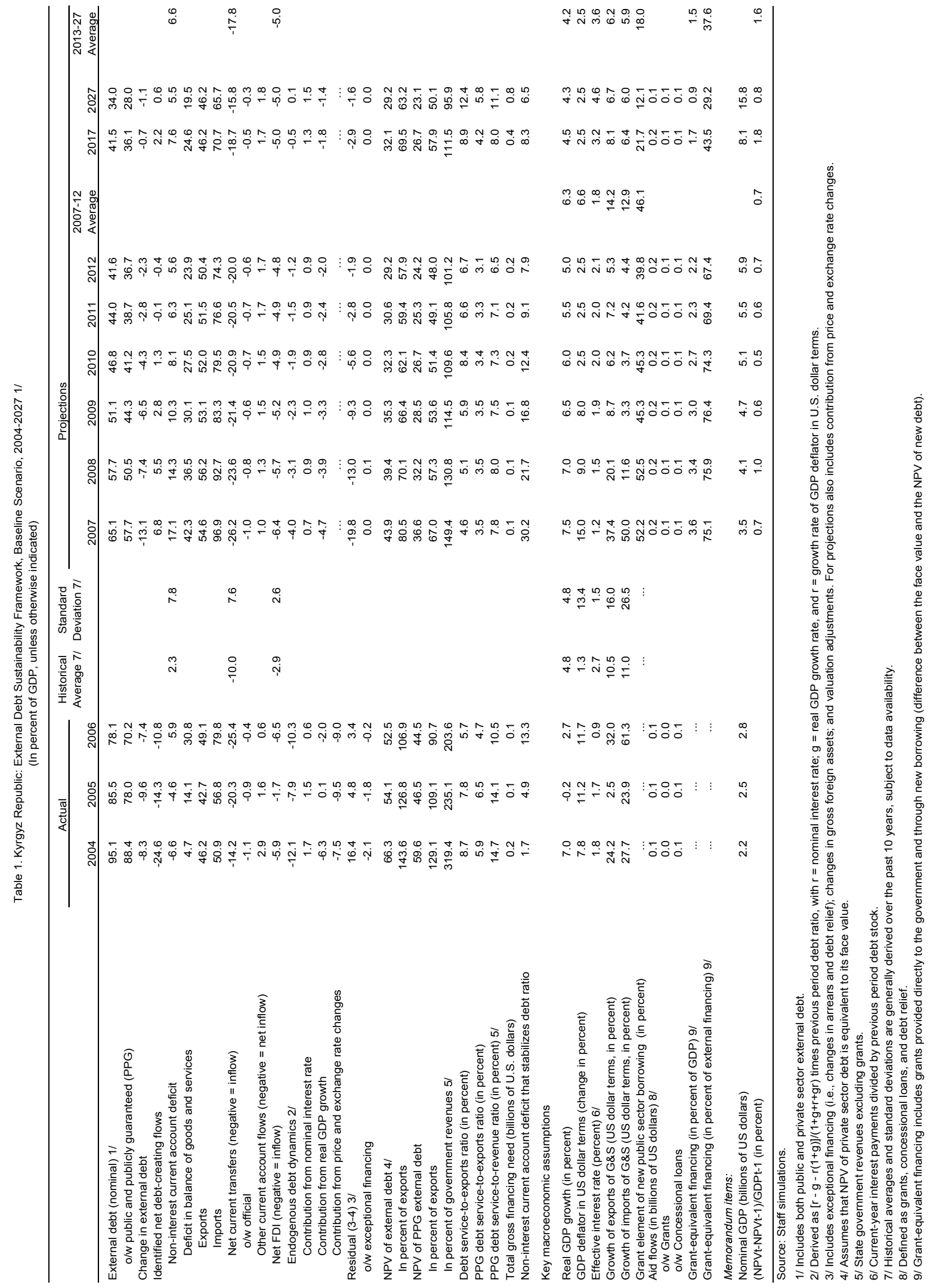


Table 2. Kyrgyz Republic: Sensitivity Analyses for Key Indicators of Public and Publicly Guaranteed External Debt, 2007-27 (In percent)

NPV of debt-to-GDP ratio

Baseline

A. Alternative Scenarios

A1. Key variables at their historical averages in 2008-27 1/

A2. New public sector loans on less favorable terms in 2008-27 2/

A3. Terms-of-trade shock (sharp decline in gold prices)

A4. Failure to reform the pension system

B. Bound Tests

B1. Real GDP growth at historical average minus one standard deviation in 2008-09

B2. Export value growth at historical average minus one standard deviation in 2008-09 3/

B3. US dollar GDP deflator at historical average minus one standard deviation in 2008-09

B4. Net non-debt creating flows at historical average minus one standard deviation in 2008-09 4/

B5. Combination of B1-B4 using one-half standard deviation shocks

B6. One-time 30 percent nominal depreciation relative to the baseline in 20085 /

NPV of debt-to-exports ratio

Baseline

A. Alternative Scenarios

A1. Key variables at their historical averages in 2007-26 1/

A2. New public sector loans on less favorable terms in 2007-26 2/

A3. Terms-of-trade shock (sharp decline in gold prices)

A4. Failure to reform the pension system

B. Bound Tests

B1. Real GDP growth at historical average minus one standard deviation in 2008-09

B2. Export value growth at historical average minus one standard deviation in 2008-09 3/

B3. US dollar GDP deflator at historical average minus one standard deviation in 2008-09

B4. Net non-debt creating flows at historical average minus one standard deviation in 2008-09 4/

B5. Combination of B1-B4 using one-half standard deviation shocks

B6. One-time 30 percent nominal depreciation relative to the baseline in 20085 /

NPV of debt-to-revenue ratio

Baseline

A. Alternative Scenarios

A1. Key variables at their historical averages in 2007-26 1/

A2. New public sector loans on less favorable terms in 2007-26 $2 /$

A3. Terms-of-trade shock (sharp decline in gold prices)

A4. Failure to reform the pension system

B. Bound Tests

B1. Real GDP growth at historical average minus one standard deviation in 2008-09

B2. Export value growth at historical average minus one standard deviation in 2008-09 3/

B3. US dollar GDP deflator at historical average minus one standard deviation in 2008-09

B4. Net non-debt creating flows at historical average minus one standard deviation in 2008-09 4/

B5. Combination of B1-B4 using one-half standard deviation shocks

B6. One-time 30 percent nominal depreciation relative to the baseline in 2008 5/
Projections

$\begin{array}{llllllll}2007 & 2008 & 2009 & 2010 & 2011 & 2012 & 2017 & 2027\end{array}$

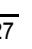

$\begin{array}{rrrrrrrr}36.6 & 32.2 & 28.5 & 26.7 & 25.3 & 24.2 & 26.7 & 23.1 \\ & & & & & & & \\ 36.6 & 28.8 & 24.0 & 21.1 & 19.7 & 19.1 & 17.2 & 21.5 \\ 36.6 & 38.7 & 39.0 & 40.9 & 40.8 & 40.5 & 52.0 & 61.5 \\ 36.6 & 32.3 & 30.6 & 32.4 & 35.1 & 38.9 & 42.3 & 30.5 \\ 36.6 & 32.2 & 28.9 & 27.8 & 27.0 & 26.7 & 34.0 & 40.8 \\ & & & & & & & \\ & & & & & & & \\ 36.6 & 34.5 & 32.5 & 30.5 & 28.8 & 27.6 & 30.5 & 26.4 \\ 36.6 & 42.2 & 51.6 & 48.9 & 46.7 & 45.0 & 42.1 & 27.9 \\ 36.6 & 39.9 & 43.5 & 40.8 & 38.6 & 36.9 & 40.8 & 35.3 \\ 36.6 & 54.4 & 68.5 & 65.1 & 62.4 & 60.2 & 53.2 & 31.2 \\ 36.6 & 65.6 & 102.5 & 97.5 & 93.4 & 90.2 & 79.2 & 45.7 \\ 36.6 & 44.4 & 39.3 & 36.9 & 34.9 & 33.4 & 36.9 & 31.9 \\ & & & & & & & \\ 67.0 & 57.3 & 53.6 & 51.4 & 49.1 & 48.0 & 57.9 & 50.1 \\ & & & & & & & \\ 67.0 & 51.3 & 45.1 & 40.6 & 38.3 & 37.8 & 37.3 & 46.7 \\ 67.0 & 68.9 & 73.4 & 78.7 & 79.2 & 80.3 & 112.6 & 133.1 \\ 67.0 & 58.5 & 58.6 & 62.2 & 65.0 & 69.8 & 78.2 & 55.9 \\ 67.0 & 57.3 & 54.3 & 53.4 & 52.5 & 52.9 & 73.7 & 88.4 \\ & & & & & & & \\ 67.0 & 57.3 & 53.6 & 51.4 & 49.1 & 48.0 & 57.9 & 50.1 \\ 67.0 & 95.4 & 141.9 & 137.6 & 132.6 & 130.4 & 133.4 & 88.3 \\ 67.0 & 57.3 & 53.6 & 51.4 & 49.1 & 48.0 & 57.9 & 50.1 \\ 67.0 & 96.7 & 128.8 & 125.3 & 121.1 & 119.3 & 115.2 & 67.7 \\ 67.0 & 113.6 & 167.5 & 163.0 & 157.5 & 155.3 & 148.9 & 85.9 \\ 67.0 & 57.3 & 53.6 & 51.4 & 49.1 & 48.0 & 57.9 & 50.1\end{array}$


Table 2 (concluded). Kyrgyz Republic: Sensitivity Analyses for Key Indicators of Public and Publicly Guaranteed External Debt, 2007-27 (In percent)

\begin{tabular}{|c|c|c|c|c|c|c|c|c|}
\hline & \multicolumn{8}{|c|}{ Projections } \\
\hline & 2007 & 2008 & 2009 & 2010 & 2011 & 2012 & 2017 & 2027 \\
\hline \multicolumn{9}{|l|}{ Debt service-to-exports ratio } \\
\hline Baseline & 3.5 & 3.5 & 3.5 & 3.4 & 3.3 & 3.1 & 4.2 & 5.8 \\
\hline \multicolumn{9}{|l|}{ A. Alternative Scenarios } \\
\hline A1. Key variables at their historical averages in 2008-27 1/ & 3.5 & 3.9 & 3.7 & 3.5 & 3.3 & 3.1 & 2.9 & 4.9 \\
\hline A2. New public sector loans on less favorable terms in $2008-27$ 2/ & 3.5 & 3.5 & 3.9 & 4.2 & 4.3 & 4.3 & 6.2 & 12.9 \\
\hline A3. Terms-of-trade shock (sharp decline in gold prices) & 3.5 & 3.6 & 3.8 & 4.0 & 4.5 & 5.0 & 7.4 & 7.1 \\
\hline A4. Failure to reform the pension system & 3.5 & 3.5 & 3.5 & 3.5 & 3.6 & 3.6 & 6.3 & 11.5 \\
\hline \multicolumn{9}{|l|}{ B. Bound Tests } \\
\hline B1. Real GDP growth at historical average minus one standard deviation in 2008-09 & 3.5 & 3.5 & 3.5 & 3.4 & 3.3 & 3.1 & 4.2 & 5.8 \\
\hline B2. Export value growth at historical average minus one standard deviation in 2008-09 3/ & 3.5 & 4.5 & 6.1 & 7.3 & 7.0 & 6.7 & 11.1 & 11.2 \\
\hline B3. US dollar GDP deflator at historical average minus one standard deviation in 2008-09 & 3.5 & 3.5 & 3.5 & 3.4 & 3.3 & 3.1 & 4.2 & 5.8 \\
\hline B4. Net non-debt creating flows at historical average minus one standard deviation in 2008-09 4/ & 3.5 & 3.5 & 4.9 & 6.2 & 5.9 & 5.7 & 10.1 & 9.0 \\
\hline B5. Combination of B1-B4 using one-half standard deviation shocks & 3.5 & 4.1 & 6.1 & 8.0 & 7.7 & 7.4 & 13.1 & 11.5 \\
\hline B6. One-time 30 percent nominal depreciation relative to the baseline in $20085 /$ & 3.5 & 3.5 & 3.5 & 3.4 & 3.3 & 3.1 & 4.2 & 5.8 \\
\hline
\end{tabular}

Debt service-to-revenue ratio 6/

Baseline

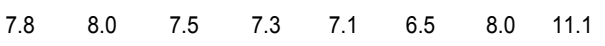

A. Alternative Scenarios

A1. Key variables at their historical averages in 2008-27 1/

A2. New public sector loans on less favorable terms in 2008-27 2/

A3. Terms-of-trade shock (sharp decline in gold prices)

A4. Failure to reform the pension system

$\begin{array}{rrrrrrrr}7.8 & 8.8 & 8.0 & 7.4 & 7.0 & 6.4 & 5.5 & 9.4 \\ 7.8 & 8.0 & 8.3 & 8.9 & 9.3 & 9.0 & 11.9 & 24.7 \\ 7.8 & 8.0 & 8.0 & 8.5 & 9.7 & 10.9 & 15.3 & 14.7 \\ 7.8 & 8.0 & 7.6 & 7.5 & 7.7 & 7.5 & 12.1 & 22.0\end{array}$

B. Bound Tests

B1. Real GDP growth at historical average minus one standard deviation in 2008-09

B2. Export value growth at historical average minus one standard deviation in 2008-09 3/

B3. US dollar GDP deflator at historical average minus one standard deviation in 2008-09

B4. Net non-debt creating flows at historical average minus one standard deviation in 2008-09 4/

B5. Combination of B1-B4 using one-half standard deviation shocks

B6. One-time 30 percent nominal depreciation relative to the baseline in 2008 5/

Memorandum item:

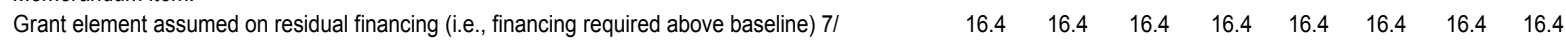

Source: Staff projections and simulations.

1/ Variables include real GDP growth, growth of GDP deflator (in U.S. dollar terms), non-interest current account in percent of GDP, and non-debt creating flows.

$2 /$ Assumes that the interest rate on new borrowing is by 2 percentage points higher than in the baseline, while grace and maturity periods as in the baseline.

3 / Exports values are assumed to remain permanently at the lower level, but the current account as a share of GDP is assumed to return are the same

to its baseline level after the shock (implicitly assuming an offsetting adjustment in import levels).

$4 /$ Includes official and private transfers and FDI.

$5 /$ Depreciation is defined as percentage decline in dollar/local currency rate, such that it never exceeds 100 percent.

6/ State government revenues excluding grants.

7/ Applies to all stress scenarios except for A2 (less favorable financing) in which the terms on all new financing are as specified in footnote 2. 


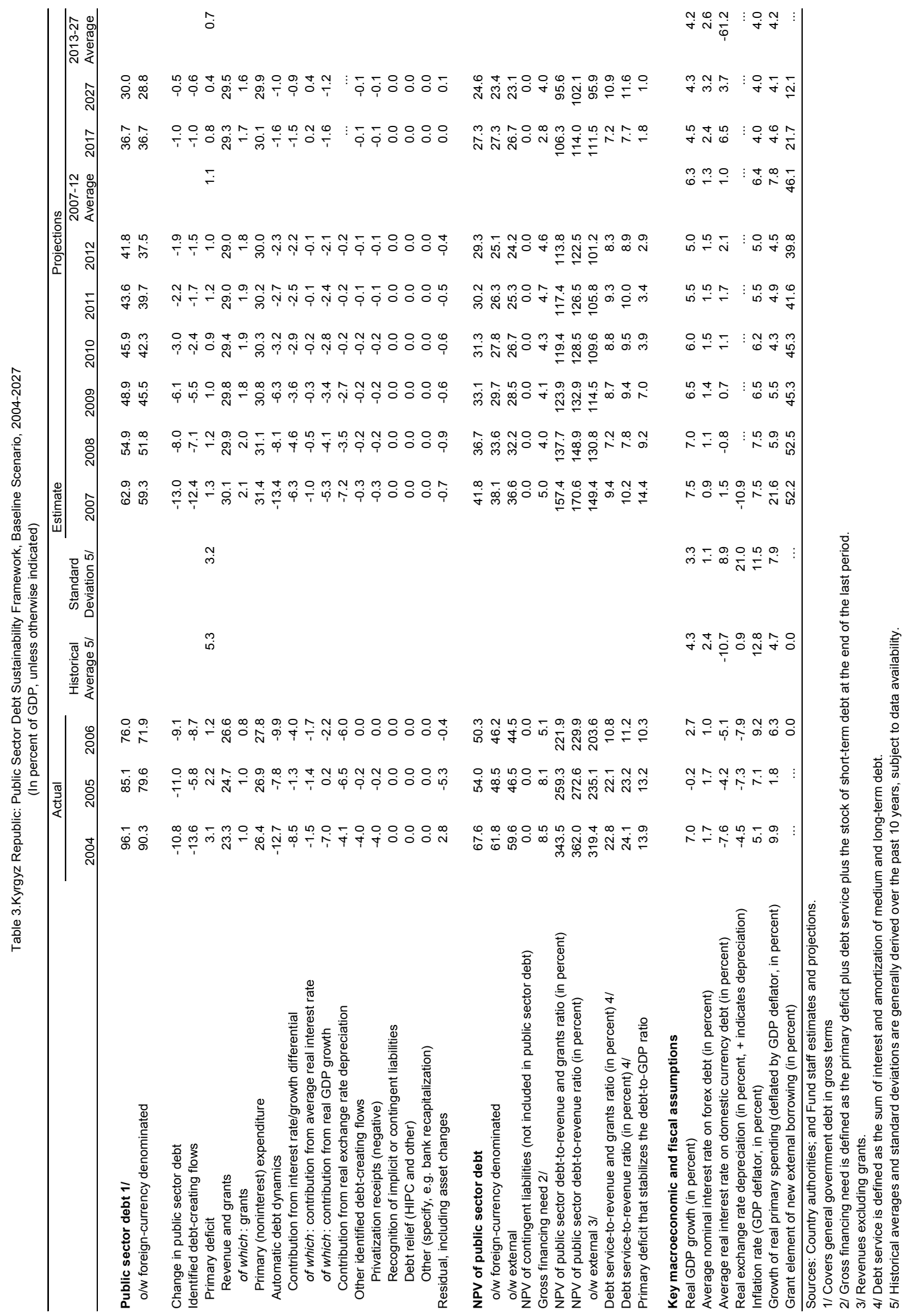


Table 4.Kyrgyz Republic: Sensitivity Analysis for Key Indicators of Public Debt 2007-2027

\begin{tabular}{|c|c|c|c|c|c|c|c|c|}
\hline & \multicolumn{8}{|c|}{ Projections } \\
\hline & 2007 & 2008 & 2009 & 2010 & 2011 & 2012 & 2017 & 2027 \\
\hline \multicolumn{9}{|l|}{ NPV of Debt-to-GDP Ratio } \\
\hline Baseline & 42 & 37 & 33 & 31 & 30 & 29 & 27 & 25 \\
\hline \multicolumn{9}{|l|}{ A. Alternative scenarios } \\
\hline A1. Real GDP growth and primary balance are at historical averages & 42 & 41 & 41 & 43 & 46 & 48 & 60 & 82 \\
\hline A2. Primary balance is unchanged from 2007 & 42 & 37 & 33 & 32 & 31 & 30 & 30 & 32 \\
\hline A3. Permanently lower GDP growth $1 /$ & 42 & 37 & 34 & 33 & 33 & 33 & 38 & 59 \\
\hline A4. Terms-of-Trade Shock (sharp decline in gold prices) & 42 & 37 & 35 & 36 & 38 & 40 & 43 & 37 \\
\hline A5. Failure to Reform the Pension System & 42 & 37 & 34 & 33 & 32 & 32 & 35 & 42 \\
\hline \multicolumn{9}{|l|}{ B. Bound tests } \\
\hline B1. Real GDP growth is at historical average minus one standard deviations in 2008-2009 & 42 & 40 & 41 & 41 & 43 & 44 & 53 & 67 \\
\hline B2. Primary balance is at historical average minus one standard deviations in 2008-2009 & 42 & 43 & 45 & 42 & 41 & 40 & 37 & 31 \\
\hline B3. Combination of B1-B2 using one half standard deviation shocks & 42 & 43 & 45 & 42 & 41 & 39 & 35 & 29 \\
\hline B4. One-time 30 percent real depreciation in 2008 & 42 & 51 & 46 & 43 & 41 & 40 & 36 & 33 \\
\hline B5. 10 percent of GDP increase in other debt-creating flows in 2008 & 42 & 45 & 41 & 39 & 37 & 36 & 33 & 29 \\
\hline \multicolumn{9}{|l|}{ NPV of Debt-to-Revenue Ratio $2 /$} \\
\hline Baseline & 157 & 138 & 124 & 119 & 117 & 114 & 106 & 96 \\
\hline \multicolumn{9}{|l|}{ A. Alternative scenarios } \\
\hline A1. Real GDP growth and primary balance are at historical averages & 157 & 154 & 155 & 166 & 178 & 187 & 236 & 322 \\
\hline A2. Primary balance is unchanged from 2007 & 157 & 138 & 125 & 122 & 120 & 118 & 118 & 123 \\
\hline A3. Permanently lower GDP growth $1 /$ & 157 & 139 & 127 & 126 & 127 & 127 & 147 & 233 \\
\hline A4. Terms-of-Trade Shock (sharp decline in gold prices) & 157 & 138 & 132 & 138 & 146 & 152 & 164 & 132 \\
\hline A5. Failure to Reform the Pension System & 157 & 138 & 126 & 124 & 125 & 125 & 137 & 161 \\
\hline \multicolumn{9}{|l|}{ B. Bound tests } \\
\hline B1. Real GDP growth is at historical average minus one standard deviations in 2008-2009 & 157 & 151 & 154 & 159 & 166 & 171 & 207 & 264 \\
\hline B2. Primary balance is at historical average minus one standard deviations in 2008-2009 & 157 & 161 & 168 & 162 & 159 & 154 & 142 & 121 \\
\hline B3. Combination of B1-B2 using one half standard deviation shocks & 157 & 162 & 169 & 162 & 159 & 153 & 139 & 115 \\
\hline B4. One-time 30 percent real depreciation in 2008 & 157 & 191 & 171 & 164 & 161 & 155 & 142 & 127 \\
\hline B5. 10 percent of GDP increase in other debt-creating flows in 2008 & 157 & 169 & 152 & 147 & 144 & 140 & 129 & 112 \\
\hline
\end{tabular}

Debt Service-to-Revenue Ratio 2/

Baseline

\section{A. Alternative scenarios}

A1. Real GDP growth and primary balance are at historical averages A2. Primary balance is unchanged from 2007

A3. Permanently lower GDP growth $1 /$

A4. Terms-of-Trade Shock (sharp decline in gold prices)

A5. Failure to Reform the Pension System

B. Bound tests

B1. Real GDP growth is at historical average minus one standard deviations in 2008-2009 B2. Primary balance is at historical average minus one standard deviations in 2008-2009

B3. Combination of B1-B2 using one half standard deviation shocks

B4. One-time 30 percent real depreciation in 2008

B5. 10 percent of GDP increase in other debt-creating flows in 2008

$\begin{array}{rrrrrrrr}9 & 7 & 12 & 13 & 14 & 14 & 17 & 31 \\ 9 & 7 & 9 & 9 & 10 & 9 & 8 & 13 \\ 9 & 7 & 9 & 9 & 10 & 9 & 10 & 22 \\ 9 & 7 & 9 & 8 & 9 & 7 & 17 & 16 \\ 9 & 7 & 9 & 9 & 10 & 10 & 11 & 21\end{array}$

Sources: Country authorities; and Fund staff estimates and projections.

1/ Assumes that real GDP growth is at baseline minus one standard deviation divided by the square root of 20 (i.e., the length of the projection period). 2/ Revenues are defined inclusive of grants. 


\section{Statement by the IMF Staff Representative November 16, 2007}

The following information has become available since the staff report was issued. It does not change the thrust of the staff appraisal.

1. Political situation. In advance of parliamentary elections scheduled for December 16, and in line with the new constitution, the prime minister and government formally resigned in late October and were reappointed on an interim basis. President Bakiev is seeking a mandate in the elections for his new party, which would likely lead to a more cooperative relationship between government and parliament.

2. Output and prices. The economy continues to rebound, with year-on-year GDP growth of $8 \frac{1}{2}$ percent in the period January-October, driven by the construction, manufacturing and services sectors. However, 12-month consumer price inflation rose further to 23 percent in October. Soaring food prices continue to be the main factor, with nonfood inflation still relatively low at $6 \frac{1}{2}$ percent. Weekly data for November suggest that price pressures may now have begun to ease, helped by the National Bank's marked tightening of monetary policy and the sharp appreciation of the exchange rate during September and early October. It is now clear that, as a result of the external shock from food prices, inflation will end the year well above the authorities' target of 9 percent, but staff considers that the policies now being implemented and described in the staff report - aimed at containing the second-round effects - remain appropriate and should result in a substantial reduction in inflation over the next few months.

3. Exchange rate. Since end-August, the exchange rate has appreciated by nearly 9 percent against the dollar. In recent weeks, the authorities have limited intervention to smoothing sharp fluctuations in the exchange rate, and the rate has been relatively stable as foreign exchange inflows appear to have slowed. International reserves remained at over $\$ 1$ billion at end-October, almost unchanged from their end-September level.

4. Banking Sector. Banking sector loans and deposits have stabilized in the past two weeks at 3-4 percent below their end-September peak levels, with deposits and loans of Kazakh-owned banks down 6-8 percent. While spillovers from the credit crunch in Kazakhstan appear to be contained so far, the central bank remains concerned and is monitoring the situation carefully.

5. Fiscal issues. Strong fiscal performance continued in the 3 rd quarter of 2007. Preliminary data for the first three-quarters indicate a fiscal surplus of over $2 \frac{1}{4}$ percent of GDP on an annualized basis, compared with a full year programmed deficit of 3 percent. This over performance is due to continued buoyancy in revenues and under execution of expenditures. The authorities have allocated some additional resources to finance the 
constitutional referendum and parliamentary elections during the 4th quarter, but substantial fiscal over performance for the year as a whole is still likely. The 2008 budget will be delayed by the parliamentary elections and will not be approved until late December, at the earliest. 
Press Release No. 07/264

FOR IMMEDIATE RELEASE

November 16, 2007
International Monetary Fund

Washington, D.C. 20431 USA

\section{IMF Executive Board Completes Fifth Review Under the PRGF Arrangement with the Kyrgyz Republic and Approves US\$2 Million Disbursement}

The Executive Board of the International Monetary Fund (IMF) today completed the fifth review of the Kyrgyz Republic's economic performance under the three-year Poverty Reduction and Growth Facility (PRGF) arrangement. The completion of this review allows the release of an amount equivalent to SDR 1.27 million (about US\$2 million). This brings total disbursements under the arrangement to SDR 7.61 million (about US\$12.1 million).

The Executive Board also approved the authorities' request to extend the PRGF arrangement until May 31, 2008 to allow for the completion of the sixth and last review. The PRGF arrangement was approved on February 23, 2005 (see Press Release No. 05/40) for an amount equivalent to SDR 8.88 million (about US\$14.1 million).

Following the Executive Board discussion of the Kyrgyz Republic's economic performance, Mr. Murilo Portugal, Deputy Managing Director and Acting Chair, said:

"The Kyrgyz economy is growing rapidly and the authorities have maintained firm macroeconomic policies, comfortably meeting the end-June 2007 quantitative targets under the PRGF-supported program. Their economic program for the remainder of 2007 and 2008 aims at limiting the inflationary impact of the recent external shock from higher food prices, while sustaining economic growth to improve living standards.

"Continuation of tight monetary policy is essential to contain the second round effects of higher international food prices. The monetary authorities are committed to restrain unsterilized intervention in the foreign exchange market, continue to enhance indirect instruments of monetary control, and raise policy interest rates further if needed. Progress in modernizing the financial sector and enhancing supervision has been encouraging. It is important to further strengthen financial sector supervision and increase the central bank's autonomy to enhance policy effectiveness. 
"Fiscal prudence needs to remain the linchpin of macro-economic stability and debt sustainability, and will require efforts to contain the upward drift in current spending observed recently. This will involve refraining from further across the board wage increases, moving forward with broad civil service reform, and designing a comprehensive pension reform that puts the pension system on a sound financial footing. Prompt passage of the new tax code would facilitate further improvements in tax administration.

"Following the authorities' decision earlier this year not to pursue debt relief under the HIPC Initiative, encouraging progress has been made in improving the Kyrgyz Republic's external debt situation, reflecting strong growth, prudent debt management, and continued fiscal consolidation. Adherence to the program commitment not to contract or guarantee nonconcessional external debt and early adoption of the medium-term debt management strategy will allow further consolidation of this progress.

"Prospects for a more cooperative relationship between the government and the new parliament set the stage for progress on the broader structural reform agenda, including critical measures to reform the energy sector and improve the business environment," Mr. Portugal said. 


\section{Statement by Thomas Moser, Executive Director for Kyrgyz Republic and Sadridden Djienbekov, Advisor to Executive Director November 16, 2007}

1. On behalf of the Kyrgyz authorities, we would like to thank the staff for the constructive policy discussions and the concise report. As pointed out, the Kyrgyz authorities continue to adhere to the PRGF-supported program; all performance criteria and structural benchmarks for end-June were observed. They have also made progress toward fulfillment of the still outstanding structural measures. Moreover, in October a new constitution and electoral code were approved at a national referendum, which together with the parliamentary election called for December should provide the basis for a restoration of political stability.

2. The economy has continued to grow strongly, with nongold output growing at almost 10 percent. Fiscal performance has been better than envisaged because of buoyant revenues as well as underspending. The revenue-to-GDP ratio now reaches an impressive 28 percent. The authorities expect the overall general government deficit for 2007 to be significantly lower than the program target of 3.1 percent of GDP. The 2008 budget sent to parliament keeps the general government deficit around 2.2 percent of GDP.

3. Currently, the main economic concern is the sharp rise in headline inflation since August. This surge largely reflects soaring international food prices (particularly wheat prices), which account for almost 50 percent of the Kyrgyz CPI. Of course, such a supply-side shock poses a substantial policy dilemma. However, the National Bank of the Kyrgyz Republic (NBKR) clearly recognizes the need to tighten monetary policy in order to contain inflationary pressures, and the authorities have raised interest rates and allowed a sharp appreciation of the exchange rate. Latest data suggest that price pressures have begun to ease. 